June 2004 - NREL/TP-510-34796

\title{
Biomass Oil Analysis: Research Needs and Recommendations
}

\section{K. Shaine Tyson, Joseph Bozell, Robert Wallace, Eugene Petersen, and Luc Moens}

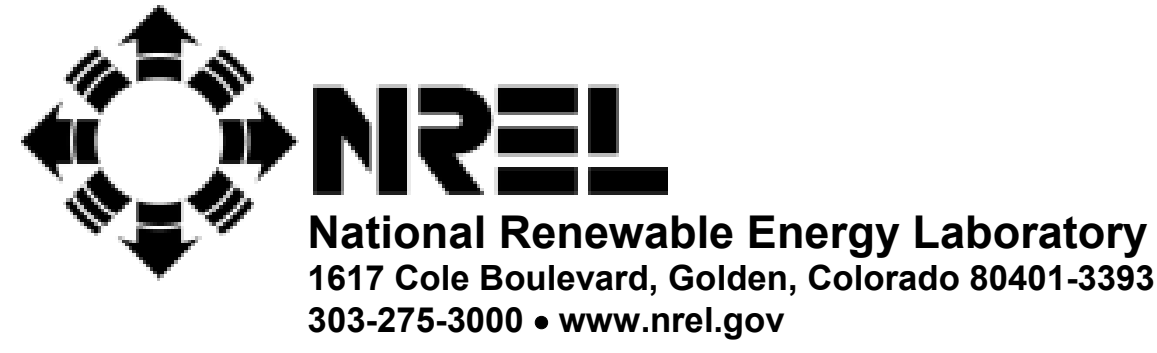

Operated for the U.S. Department of Energy Office of Energy Efficiency and Renewable Energy by Midwest Research Institute • Battelle 


\section{Biomass Oil Analysis: Research Needs and Recommendations}

\section{K. Shaine Tyson, Joseph Bozell, Robert Wallace, Eugene Petersen, and Luc Moens}

Prepared under Task No.BBA35210 and BBA35410

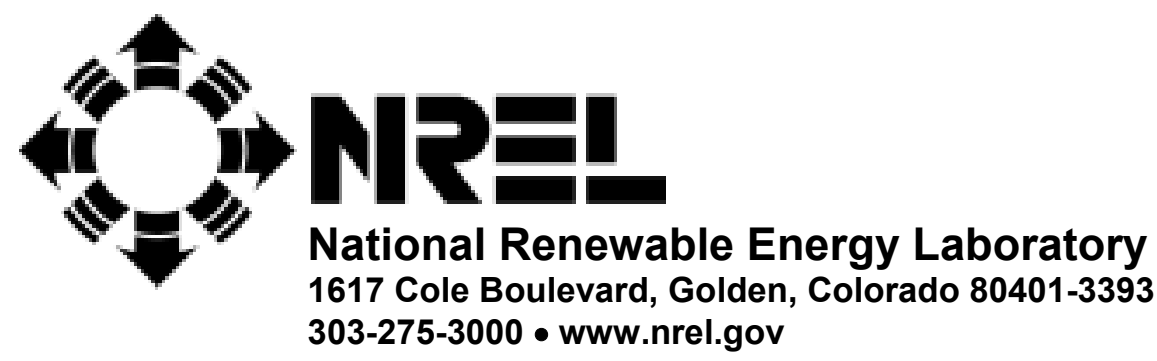

Operated for the U.S. Department of Energy Office of Energy Efficiency and Renewable Energy by Midwest Research Institute • Battelle 


\section{NOTICE}

This report was prepared as an account of work sponsored by an agency of the United States government. Neither the United States government nor any agency thereof, nor any of their employees, makes any warranty, express or implied, or assumes any legal liability or responsibility for the accuracy, completeness, or usefulness of any information, apparatus, product, or process disclosed, or represents that its use would not infringe privately owned rights. Reference herein to any specific commercial product, process, or service by trade name, trademark, manufacturer, or otherwise does not necessarily constitute or imply its endorsement, recommendation, or favoring by the United States government or any agency thereof. The views and opinions of authors expressed herein do not necessarily state or reflect those of the United States government or any agency thereof.

Available electronically at http://www.osti.gov/bridge

Available for a processing fee to U.S. Department of Energy and its contractors, in paper, from:

U.S. Department of Energy

Office of Scientific and Technical Information

P.O. Box 62

Oak Ridge, TN 37831-0062

phone: 865.576 .8401

fax: 865.576 .5728

email: mailto:reports@adonis.osti.gov

Available for sale to the public, in paper, from:

U.S. Department of Commerce

National Technical Information Service

5285 Port Royal Road

Springfield, VA 22161

phone: 800.553.6847

fax: 703.605.6900

email: orders@ntis.fedworld.gov

online ordering: http://www.ntis.gov/ordering.htm 


\section{EXECUTIVE SUMMARY}

The United States Department of Energy's (DOE) Office of Energy Efficiency and Renewable Energy (EERE) invests in research to achieve the following goals:

- Dramatically reduce, or even end, dependence on foreign oil;

- Spur the creation of a domestic bioindustry.

The Office of The Biomass Program (OBP) within EERE invests in technology research and development (R\&D) to support those goals and to achieve the following outcomes:

1. Establish commercial biorefinery technology by 2010

2. Commercialize at least four biobased products.

These outcomes can be achieved by concentrating investments in research platforms that show the highest likelihood of success and/or the largest impact. OBP faces a large portfolio of R\&D options with limited resources. As a result, only those investments that offer the largest benefits can be funded. This analysis provides inputs for the decision-making process.

The biomass feedstocks evaluated in this report are lipids from animal fats, fish and poultry oils, plant oils, and recycled cooking greases. These feedstocks shall be referred to as biomass oils.

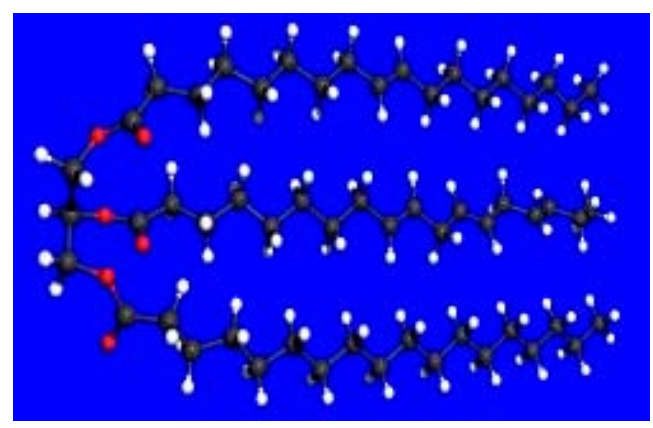

Figure 1. Biomass oil molecule

\section{Findings}

The conclusions of this analysis can guide OBP R\&D investments in alignment with their goals and desired outcomes.

- Biomass oils can displace up to 10 billion gallons of petroleum by 2030 if incentives or mandates are used to promote fuels and biobased products produced from biomass oils.

- Biomass oils can be used as fuels in a variety of ways: directly as boiler fuels, processed into biodiesel (fatty acid methyl esters), or processed into "bio-distillates" via refinery technology. 
- With incentives, both biodiesel and bio-distillates offer major oil displacement potential. One fuel is not exclusive of the other, as regional and local market conditions may favor one fuel over the other.

- Blends of biomass oil fuels with petroleum fuels offer the best commercial potential because blends offer superior performance and lower cost than the straight biomass oil fuels themselves.

- The oleochemical industry has already commercialized biomass oil biorefineries. This mature industry consumes 2.6 billion pounds of biomass oil and produces nearly 4 billion pounds of biobased products, chemicals, fuel additives, and biodiesel annually.

- Oleochemicals compete with petrochemicals in many markets on a price and performance basis (detergents, lubricants, solvents, coatings, polymers, etc). Biobased purchasing incentives or financial incentives that reduce biomass oil feedstock costs visà-vis petroleum feedstock costs could increase demand for oleochemical products and displace some petrochemical products. There is some potential to increase the oleochemical content of some petrochemical products as well.

- Methyl esters (aka biodiesel) is one of two primary platform chemicals for the oleochemical industry. The production of methyl esters is highly efficient (yields exceeding 99.7\%) and their total average production costs are minimized given the constraints of feedstock costs and economies of scale. Investments in processing technology have a limited impact on production costs.

- Glycerin (a crude mixture of glycerol and other impurities) is an inevitable coproduct of biodiesel and oleochemical production. Federal investment in biodiesel catalyst R\&D, in particular fixed base catalysts and fixed dual-purpose acid-base catalysts, can improve glycerin coproduct quality and reduce glycerin-refining costs. In turn, this can expand the ability of biodiesel plants to produce glycerol-base coproducts and generate higher values for their glycerol streams.

- Biodiesel expansion will flood the United States and international markets with glycerin. Federal investments in new uses for glycerin and new products produced from glycerol can enable the rapid expansion of a biodiesel or oleochemical industry.

- Methyl esters are used to produce a wide variety of fatty acid coproducts, however, fatty acid coproduct revenues cannot be leveraged to reduce methyl ester production costs. Oleochemical firms will not use coproduct profits to subsidize fuel prices (the breakeven approach to fuel cost estimation). Coproducts generate profits, increase returns to equity, and generally attract investment in biobased product expansion.

- The mature status of the oleochemical industry stymies the typical rationales for biobased product investment. There are opportunities to invest in new oleochemical technologies, particularly in research focused on unsaturated fatty acid feedstocks. However, it is difficult to make the argument that the oleochemical industry lacks the technology or 
resources to make these investments themselves. Federal investment in fatty acid product research should be focused on displacing petroleum by displacing petrochemicals, reducing energy processing costs, or both to bring investments in line with EERE goals.

- Federal investment can expand the future supplies of biomass oils through crop R\&D with a focus on increasing yields and reducing costs of high oil seed crops (canola, sunflower, etc.) increasing oil content of soy beans, increasing demand for soy bean meal, and investments in manufactured oils from yeasts, fungus, bacteria, and similar microorganisms that can be produced with minimal land or sunlight investments.

- Federal investment can reduce the cost of biomass oil feedstocks (for fuel and biobased products) through $\mathrm{R} \& \mathrm{D}$ to increase crop yields and reduce production costs of high oil content seeds (canola, sunflower, etc.), increasing demand for soy bean meal via coproduct development, and investments in manufactured oils from yeasts, fungus, bacteria, and similar microorganisms that can be produced with minimal land or sunlight investments.

- Unless an industry partner is willing to assume the costs of commercializing new fuel or fuel additive products, federal investment in these two areas should be avoided. The commercialization costs of new fuels and fuel additives can equal or exceed \$30 million.

- Federal investments in lubricants, fuels, and other products should be compared on a basis of petroleum displacement $(\$ / \mathrm{bbl})$ to determine the value and rank biobased product and fuel programs.

\section{Recommendations}

In order for biomass oils to displace large quantities of petroleum there must be a wellcoordinated research program between USDA and DOE. In addition, there has to be a clear policy environment that encourages the use of biomass oil fuels and products using tools such as purchasing incentives, tax credits, or mandates. Mandates will be the least expensive of the options but incentives are more politically popular. Some realignment of other subsidies, such as oil and soybean export incentives and farm support payments could be redirected into incentive programs. Long-term incentive costs depend on the differential between biomass oil prices and distillate prices as crude oil prices rise.

Without incentives, there is no justification for significant DOE R\&D in an oils platform, because OBP-funded research can minimize but not eliminate feedstock and production cost barriers for biomass oil fuels and products. Most biomass oils feedstocks exceed distillate prices, limiting petroleum displacement. Without financial incentives, biomass oil fuels will remain niche market fuels where there are environmental or political incentives to use them.

Government purchasing preferences may increase demand for some oleochemical products.

If incentives or mandates are instituted, then there are clear priorities for OBP R\&D investments. The R\&D areas that have the most value to OBP are ranked below from highest to lowest. 
1 Demonstrate and optimize commercial bio-distillate production (industrial partnership)

2 Demonstrate and optimize $\mathrm{CO}_{2}$ oil extraction technology (program R\&D and or solicitation)

3 Develop and optimize fixed base and acid-base esterification catalysts that reduce glycerin refining costs (program R\&D and or solicitation)

4 Support industry development of coproducts from glycerol or glycerin (solicitation )

5 Support industry development of industrial products from meals (solicitation)

6 Increase oil supplies by developing closed loop microorganism production systems (program and solicitation)

Bio-distillation: Bio-distillation converts biomass oils into hydrocarbon fuels using existing petroleum refinery technology with minor modifications. Researchers in Canada and the United States have demonstrated the potential of this approach on a small scale. Bio-distillation was ranked number one for several reasons. The benefits of this approach are significant in that production and distribution costs can be minimized, the existing infrastructure is used (no duplicate infrastructure), and key political barriers are addressed. The technological barriers and limits need to be identified and understood. Among these questions are concerns about technical limits on refining volumes of biomass oils; is it limited to $2 \%$ or is $10 \%$ an attainable goal? Will this technology maximize oil displacement or must we also encourage biodiesel production? What are the feedstock quality issues and are they significant barriers in terms of reducing oil displacement potential or raising costs? What level of incentive would be necessary to break even with vegetable oil feedstocks (the only expandable feedstock supply)?

Oil Extraction Technology: Since biomass oil extraction can cost 20 to 44 cents per gallon of oil and up, it provides a large target for cost reductions. Only oil seed costs are higher. Improved oil extraction technology could benefit the existing crushing industry by developing a process that does not use toxic compounds such as $n$-hexane. Improved extraction technology can also reduce oil pretreatment costs, for an additional feedstock cost savings.

Super critical $\mathrm{CO}_{2}$ oil extraction technology offers some benefits in terms of lower costs, higher oil quality (less pretreatment required), and is suitable for smaller plants. Crown Iron Works has demonstrated this technology in a 50 ton per day crushing pilot plant in MN. The process can accommodate a seed moisture content up to $11 \%$ (saves on drying costs), does not require purified $\mathrm{CO}_{2}$, and the oil quality is similar to refined, bleached, and deodorized soy oil (RBD soy oil). Internal cost estimates indicate that this process can be more cost effective than small mechanical crushers that produce crude oil (typically smaller than 500 tons per day). Additional savings are generated because the processes that are typically used to create RBD oil from crude oil are avoided, saving as much as 5 cents per pound or 38.5 cents per gallon of RBD oil. This technology requires demonstration and optimization. The EPA is pushing the industry to develop a viable non-hexane substitute so there may be a timely window of opportunity to adopt new technology throughout the entire industry. In addition, new technology would lower the cost structure of the entire United States crushing industry and provide it with a competitive advantage once again.

Industrial Meal Coproducts: Developing new meal coproducts will stimulate the existing crushing industry, expanding oil supplies and reducing their costs. Demand for soybean meal 
drives the U.S. crushing industry; demand for oil has no real effect on supplies of soybean oil because it's a minor byproduct representing only $19 \%$ of the soybean by weight. If the demand for meal in industrial coproducts or applications is stimulated, crushing capacity utilization will increase and the amount of oil produced will increase. The price for oils may fall as oil supplies and crusher's revenues expand. There are large numbers of new uses for soy meal in human food, health products, and industrial products. USDA supports food product development and DOE could support industrial product development. A solicitation may be offered every year until a large market meal coproduct is identified that meets OBP's needs. There are numerous industrial partners with solid credentials to work with in this category (United Soybean Board, Battelle National Laboratories, ADM, Cargill, Bunge, AGP, etc.).

Reduce Glycerin Refining Costs: An inevitable byproduct of biodiesel production is glycerolabout 0.73 pounds per gallon of biodiesel. The expansion of biodiesel production worldwide is driving down the value of glycerol and reducing byproduct revenue of biodiesel and oleochemical producers. Further expansion of the biodiesel industry will produce as much as one billions pounds of glycerol and reduce its price to a point where it may become a useful platform chemical. However, biodiesel-derived glycerol is poor quality and requires expensive refining before it is suitable for new product technologies. Glycerol refining technology is relatively mature and requires significant economies of scale to be economical.

The potential research avenues are:

1. Produce products from crude glycerol in situ followed by product separation

2. Improve biodiesel technology to produce higher quality glycerol

3. Develop glycerol-refining technology suitable for small biodiesel producers.

Of these options, the one that can simultaneously reduce biodiesel production costs, glycerol refining costs, and increase byproduct revenues is the second option above. A new technology that eliminates mobile catalysts and replaces them with fixed catalysts, or a catalyst-free technology will achieve that goal. These topics could be included in SBIRs and other solicitations to promote improvements in the biodiesel industry.

Develop Glycerol Coproduct Technology: The target markets for glycerol coproducts must be large, as future supplies from a biodiesel driven industry will create billions of pounds of glycerol. Typical prices for chemicals produced in these large volumes rarely exceed 50 cents a pound. There are three directions that research could focus on:

1. develop new market uses for crude (unrefined) glycerin

2. develop new chemistry or products that are chemical derivatives of purified glycerol

3. develop new chemistry or products from crude glycerin in situ.

Near term DOE assistance can be provided through SBIRs or solicitations with industry partners. As industry identifies products or product chemistries with large-scale market potential, the research needed to move these concepts into commercial status will be better defined, and the role of DOE can be identified. 
Fuel uses for glycerin are attractive from a large market perspective but should be avoided unless there is compelling evidence that 1) the glycerin does not cause long term engine damage as seen in previous research studies, 2) the price structure of the resulting compound can be supported by the fuel market and 3) the industry is willing to partner with DOE to support the $\$ 30$ million dollars required to commercialize a new fuel or fuel additive.

Oilseed Crop Improvements: Expanding supplies are necessary to maximize petroleum displacement potential. Improvements can also reduce oil production costs. Other than crushing, the single largest cost to produce biomass oils is the production cost of oilseeds ( $\$ 0.75$ per gallon oil to over \$1.00). Many of the potential activities in this arena are best suited to the USDA. However, there is one promising area that is suitable for OBP investments.

Yeasts, molds, fungi, and bacteria can be genetically optimized and used to produce oils in closed manufacturing systems using inexpensive biomass substrates such as crop residues, wood wastes, MSW biomass, or even pyrolysis oils. The non-oil portions of these organisms can be recycled back into production systems, making them truly closed looped. These organisms offer a couple of key benefits compared to the previous EERE micro algae program-major land resources and water resource are not required and the genetically modified organisms are not exposed to the open environment, wildlife, or accidental release. In addition, many of these organisms do not require sunlight for photosynthesis.

Since closed looped production of micro organisms resembles manufacturing rather than agriculture, it is one feedstock supply research role that might be best suited to DOE. Particularly since DOE has already invested research in some of these areas in the past and has a significant body of knowledge to start from. Some inexpensive stage gate analysis and solicitations could be undertaken in the near term to collect information and assess possible pathways for closed loop production of microorganisms. This will lay a foundation for program elements when they become necessary. If these early analyses reveal major benefits (significant oil supplies at exceptionally low costs) then the priority of this program element can be raised and research accelerated.

Program Costs: Because the cost of these research elements will be defined in proposals as a result of solicitations and then balanced against other program needs, it is difficult to estimate program costs in advance. Historically the biodiesel program, and its successor, the Renewable Diesel Program that supported these research areas, operated on a budget that varied from $\$ 750,000$ to $\$ 1.5$ million per year. Most of the funding was directed towards technical barriers facing the use of biodiesel and E-diesel fuels, since this budget level was too small for process demonstrations and optimization. If OBP focuses a fraction of their program towards production technology in the areas identified above, $\$ 2$ to $\$ 5$ million per year may be sufficient with careful time phasing of priorities and a focus on only one key element at a time.

Program Timing and Life: The objectives of this research program are relatively concrete and have definite termination points. 
Table 1. Biomass Oil R\&D Project Schedule

\begin{tabular}{|l|l|l|l|l|l|l|l|l|l|l|l|}
\hline & 2005 & 2006 & 2007 & 2008 & 2009 & 2010 & 2011 & 2012 & 2013 & 2014 & 2015 \\
\hline $\begin{array}{l}\text { Bio-distillation process } \\
\text { optimization }\end{array}$ & RFP & & & & & & & & & & \\
\hline $\begin{array}{l}\text { Improved oil extraction } \\
\text { technology }\end{array}$ & RFP & & & & & & & & & & \\
\hline $\begin{array}{l}\text { Develop industrial } \\
\text { products from meal }\end{array}$ & RFP & RFP & & & & & & & & & \\
\hline $\begin{array}{l}\text { Improved glycerin } \\
\text { refining technology }\end{array}$ & & & & RFP & & & & & & & \\
\hline $\begin{array}{l}\text { Coproducts from } \\
\text { glycerin/glycerol }\end{array}$ & & & & & RFP & RFP & & & & & \\
\hline $\begin{array}{l}\text { Develop closed loop oil } \\
\text { producing } \\
\text { microorganisms }\end{array}$ & & & & & & & & & & & \\
\hline
\end{tabular}

Benefits and Outcomes The result of OBP investment in biomass oil R\&D is to create the opportunity to displace up to 10 billion gallons of petroleum diesel per year by 2030 . The resulting fuel costs will appear reasonable to the consumer in blends of 5\% (5 to 10 cent per gallon premium). Currently, blends of $2 \%$ or more biodiesel are marketed as premium fuels, where the value of the fuel benefits offset the additional costs. Higher blends, such as B20 can continue to be marketed where global warming, emission, or other environmental benefits offset the cost of the fuel. At least two different fuels are available as vehicles for this program, providing flexibility and insurance. There are only minor technical barriers associated with the fuels themselves that will not pose significant barriers to market expansion. 


\section{TABLE OF CONTENTS}

1 DOE Goals and Objectives Relative to the Oil Platform Analysis..................................

2 Biomass Oil and Distillate Fuels................................................................................

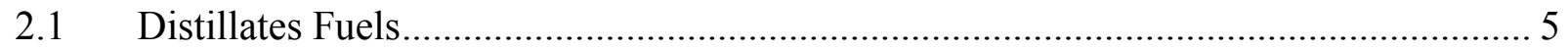

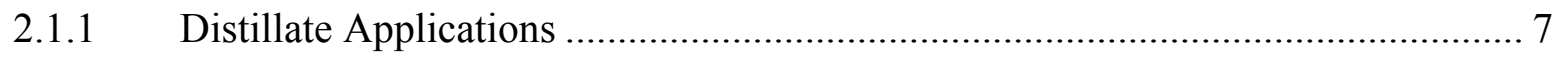

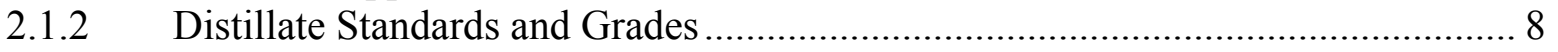

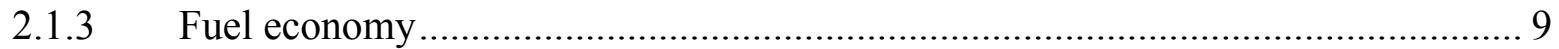

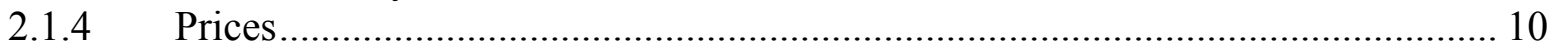

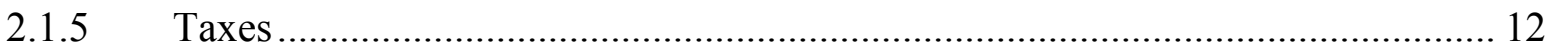

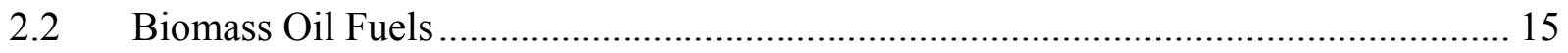

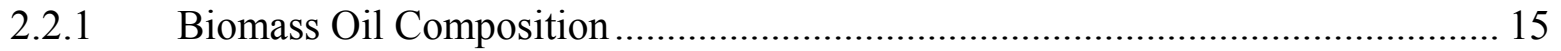

2.2.2 Unconverted Fats and Oils as Boiler Fuels.................................................... 19

2.2.3 Biomass Oils as Highway Diesel Fuel............................................................. 19

2.2.4 Pure Biodiesel (B100) .............................................................................. 21

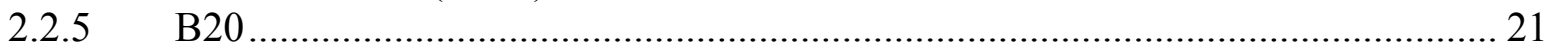

2.2.6 Low Level Blends (B2 to B5) ....................................................................... 24

2.2.7 Heating oil blends with biodiesel............................................................. 25

2.2.8 Biomass Oils as Hydrogen Feedstocks ........................................................... 27

2.2.9 Converting Biomass Oils to Hydrocarbon Fuels .............................................. 27

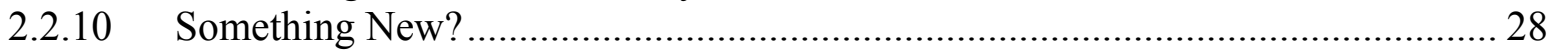

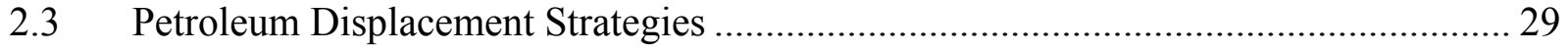

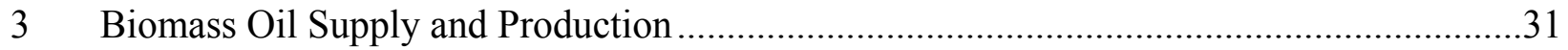

3.1 Current Biomass Oil Supply ................................................................................ 31

3.2 Near Term Expansion Potential (2015) ................................................................... 35

3.2.1 Basic Crushing Costs and Implications ........................................................... 35

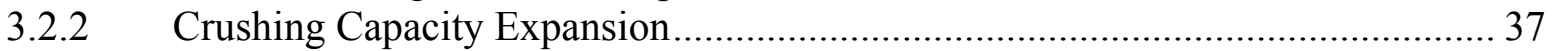

3.2.3 Land Availability for Expansion.................................................................. 39

3.2.4 Slow Growth in Available Animal Fats and Grease Supplies ........................... 42

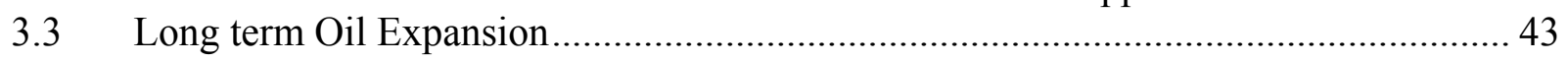

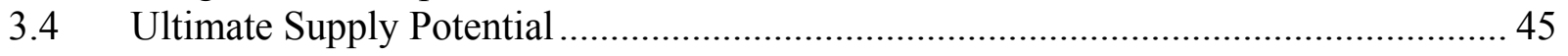

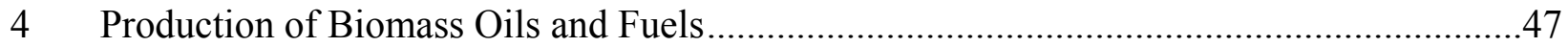

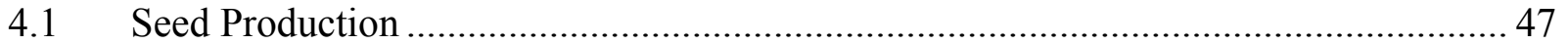

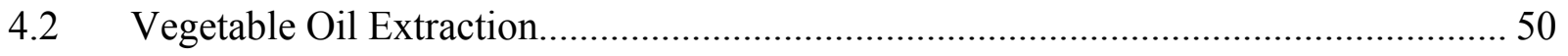

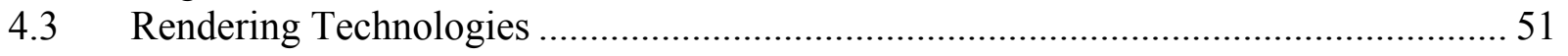

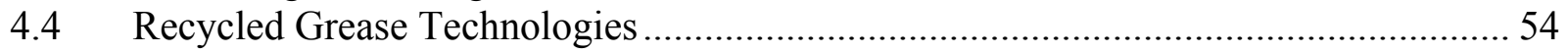

4.5 Biodiesel Production Technology......................................................................... 55

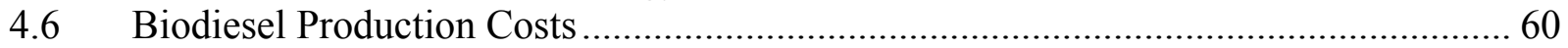

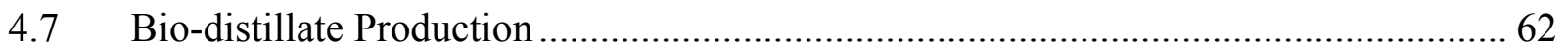




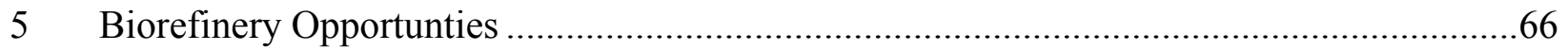

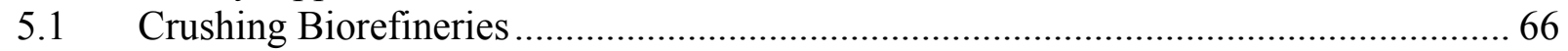

5.2 Oleochemical Biorefineries ................................................................................ 72

5.2.1 Glycerol Contribution to Biorefineries ……….................................................. 73

5.2.2 New Chemical Modifications of Glycerol.......................................................... 76

5.2.3 Selective Oxidation of Glycerol......................................................................... 78

5.2.4 Glycerol Carbonate as a New Solvent and Product ............................................... 78

5.2.5 Glycerol as a Component of New Polymers........................................................ 78

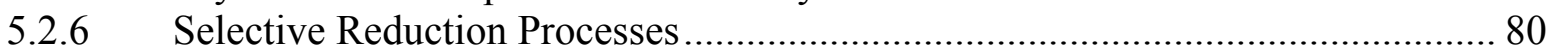

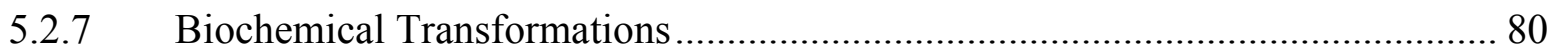

5.3 Feedstock Integration with Biorefineries .................................................................... 82

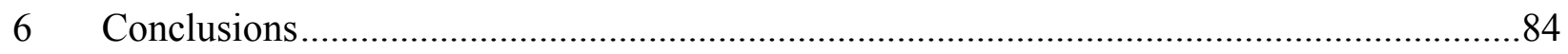

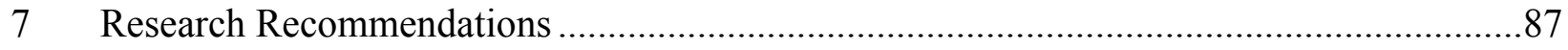

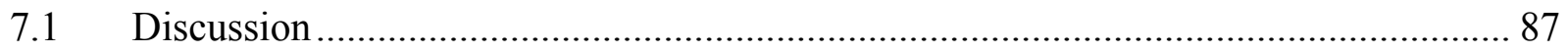

Appendix A: Oleochemcial Products 


\section{TABLES}

Table 1. Biomass Oil R\&D Project Schedule vii

Table 2. United States Distillate Fuel Demand Forecast by End Use Segment ..... 7

Table 3. Supplier Monthly Sales Volume of Distillate Fuel Oils and Kerosene,

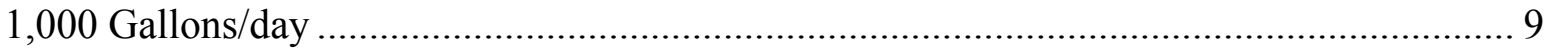

Table 4. Biomass Oil Composition and Impact on Fuel Properties............................................... 16

Table 5. Structural Formula, Melting and Boiling Points for Fatty Acids and Fatty Acid

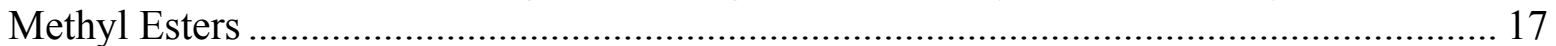

Table 6. Weight Percent of Fatty Acids in Fat and Oil Feedstocks............................................. 18

Table 7. Market Penetration Scenarios for Biomass Oils in Boiler Fuel Markets......................... 19

Table 8. On-road Market Penetration Scenario for B100 used for B20 Fuels............................... 23

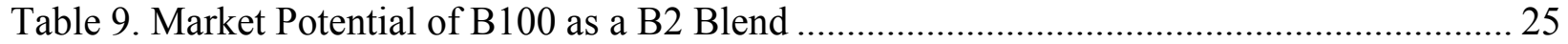

Table 10. Residential Heating Oil Displacement Scenarios ......................................................... 26

Table 11. United States Production, Imports, Exports, and Apparent Consumption of Fats

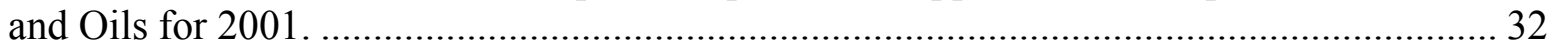

Table 12. Current Biomass Oil Supplies Available for Energy Use in 2001 ............................... 34

Table 13. United States Production of Seed Oils and Equivalent Biodiesel per Acre, 2001........ 35

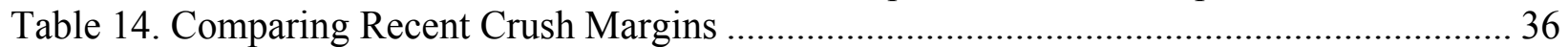

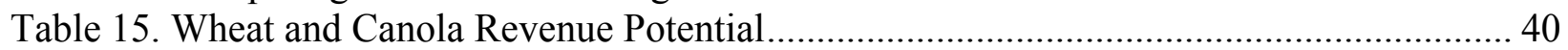

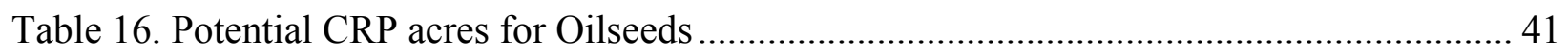

Table 17. Near Term Growth Potential in Vegetable Oils......................................................... 42

Table 18. Highway Diesel Market Penetration 2015 .................................................................... 42

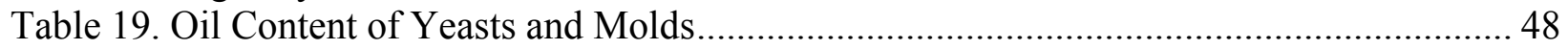

Table 20. Average Compositions for Crude and Refined Soybean Oil........................................ 51

Table 21. American Fats and Oils Association Specifications for Tallow and Greases................53 53

Table 22. Commercial and Precommercial Biodiesel Technologies Available, 2004 ................. 57

Table 23. Biodiesel Production Costs by Feedstock and Process Technology............................... 60

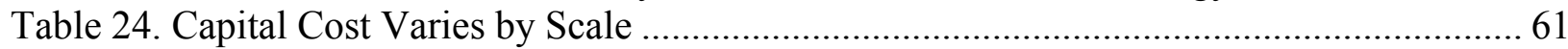

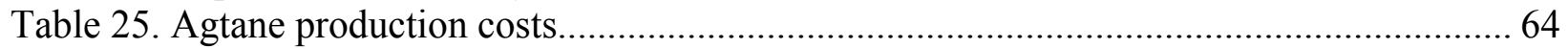

Table 26. Comparative Composition of Various Oilseed Meals ................................................... 67

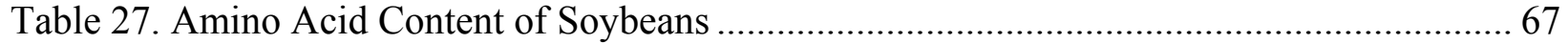

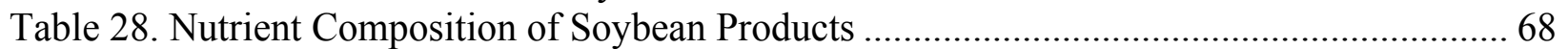

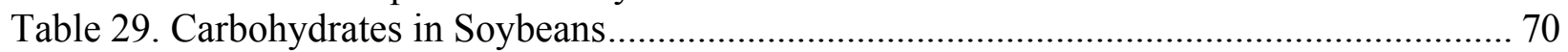

Table 30 North American Consumption of Fatty Acids by Market Segment ............................. 73

Table 31. Fatty Acid Compounds Produced by Oleochemical Industry ...................................... 74

Table 32. Projected Impact on United States Glycerol Supplies from Biodiesel ........................... 75

Table 33. Translation of Branched Polymer Physical Properties into Potential Marketplace

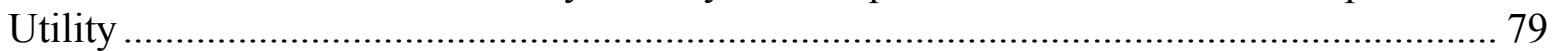

Table 34. - Sizes of Various Market Segments Related to the Use of Branched Polymers......... 80

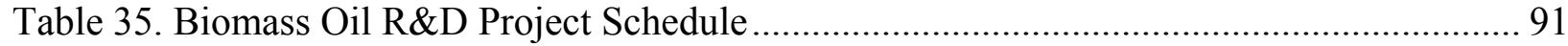

Table 36- Industrial Consumption of Metal Stearates ………..................................................... 2

Table 37. Distribution of Fatty Alcohol Products in North America, Western Europe,

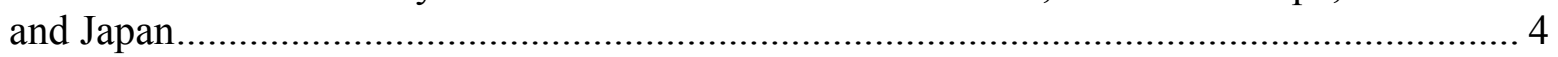

Table 38. Comparative Prices of Natural and Synthetic Detergent Alcohols - 1999...................... 6

Table 39 Uses of Glycerol, 1995 (source: Claude, S. Fett/Lipid 1999, 101, 101)......................... 7

Table 40. Table - Production, Consumption, and Uses of Glycerol, 2001 ................................. 8 


\section{FIGURES}

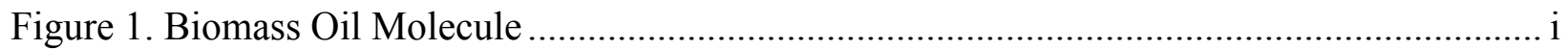

Figure 2. Triglyceride Molecule .......................................................................................... 1

Figure 3. Crude Oil Distillation: The first step................................................................. 5

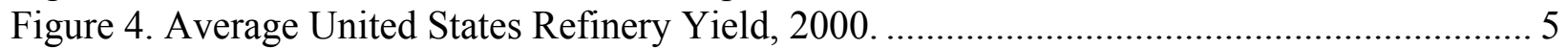

Figure 5. Energy Content of Petroleum Fuels and Biomass Oil Fuels ....................................... 10

Figure 6. Petroleum and Distillate Fuel Prices, Excluding Taxes ............................................ 10

Figure 7. Recent Biomass Oil Prices .................................................................................... 11

Figure 8. Retail (before tax) prices of Diesel No. 2, Biodiesel, and Blends ............................... 12

Figure 9. Biodiesel and Biodiesel Blend Prices Including Proposed Federal Excise Tax

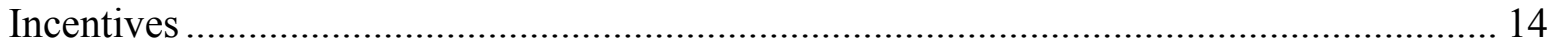

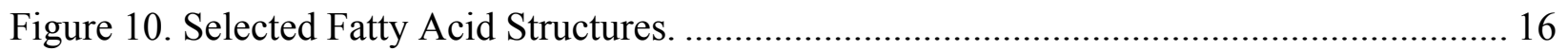

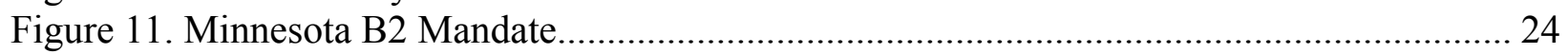

Figure 12. Cold Filter Plug Point for Low-Blend Biodiesel Fuels ............................................. 25

Figure 13. United States Petroleum Supply Forecast, AEO 2003 Early Release, Table 11_........ 31

Figure 14. Fat and Oil Consumption and Use in Industrial Products, Millions of pounds 2001.. 33

Figure 15. World Soy Oil Production, Millions Metric Tonnes per Crop Year. ........................... 38

Figure 16. Production Costs per Acre, Soybeans 1997. ........................................................... 47

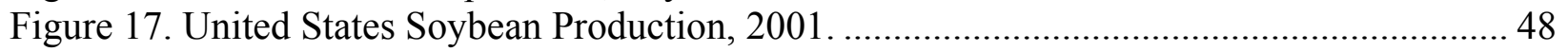

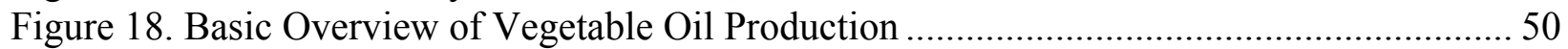

Figure 19. Rendering Process Flow Diagram ....................................................................... 52

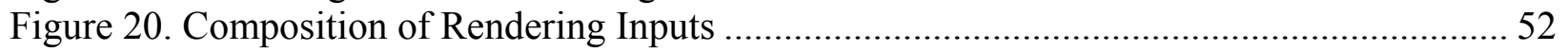

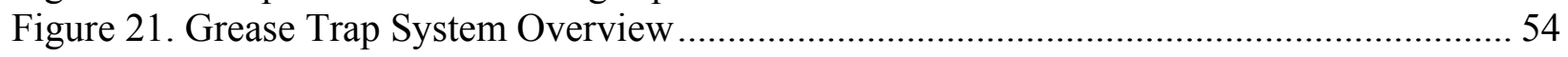

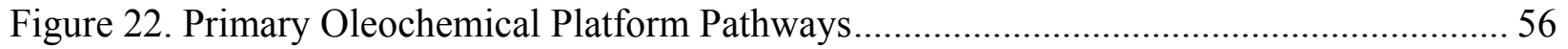

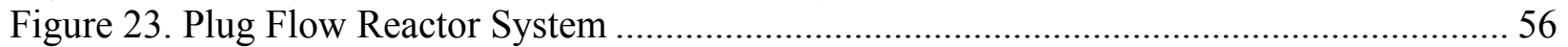

Figure 24. Typical Soy Protein, Battelle Memorial Institute............................................................ 69

Figure 25. United Soybean Board Success Stories: Commercial Products from Soybeans........ 71

Figure 26. Inter-relationships Between Triaclyglycerols and their Derivatives ........................... 72

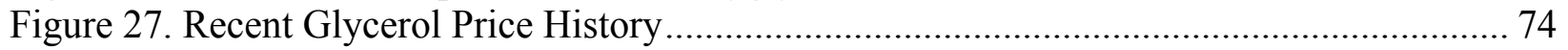

Figure 28. Families of Possible Glycerol Reactions ………....................................................... 77 


\section{ACRONYMS AND ABBREVIATIONS}

\begin{tabular}{ll} 
A & acre \\
ARS & USDA Agricultural Research Service \\
ASA & American Soybean Association \\
ASTM & American Society for Testing and Materials International \\
B100 & pure biodiesel, 100\% long chain mono alkyl esters of fatty acids \\
B20 & $20 \%$ biodiesel, $80 \%$ conventional diesel \\
B2 & $2 \%$ biodiesel, $98 \%$ conventional diesel fuel \\
Bb1 & barrel \\
BSE & bovine spongiform encephalopathy \\
CI & Compression ignition engine (diesel engines) \\
CCC & USDA's Commodity Credit Corporation \\
DDGS & distiller's dry grains with solubles \\
DOE & United States Department of Energy \\
EERE & Energy Efficiency and Renewable Energy Office of DOE \\
EIA & Energy Information Administration of the DOE \\
EPA & United States Environmental Protection Agency \\
ERS & USDA Economic Research Service \\
FA & fatty acid \\
FAME & fatty acid methyl esters \\
FCVT & FreedomCAR and Vehicle Technologies \\
FDA & Food and Drug Administration \\
FFA & Free fatty acid \\
Gal & gallon \\
GMO & genetically modified organism \\
lb & pound \\
MIU & Moisture, impurities and unsaponified materials \\
NBB & National Biodiesel Board \\
NREL & National Renewable Energy Laboratory \\
OBP & Office of the Biomass Program \\
RBD & Refined bleached and deodorized \\
R\&D & research and development \\
SVO & Straight vegetable oil \\
USB & United Soybean Board \\
USDA & United States Department of Agriculture \\
WVO & Waste vegetable oil \\
YG & Yellow grease \\
\hline
\end{tabular}




\section{DOE GOALS AND OBJECTIVES RELATIVE TO THE OIL PLATFORM ANALYSIS}

The United States Department of Energy's (DOE) Office of Energy Efficiency and Renewable Energy (EERE) invests in research to achieve the following goals:

- Dramatically reduce, or even end, dependence on foreign oil

- Spur the creation of a domestic bioindustry.

The Office of The Biomass Program (OBP) within EERE invests in R\&D to support those goals and to achieve the following outcomes:

- Establish commercial biorefinery technology by 2010

- Commercialize at least four biobased products.

These outcomes can be achieved by concentrating investments where they will produce the highest likelihood of success and/or the largest impact. OBP faces a large portfolio of R\&D options with limited resources. As a result, only those investments that offer the largest benefits can be funded. This analysis provides inputs for those decision-making processes.

The biomass feedstocks evaluated in this report are lipids from animal fats, fish and poultry oils, plant oils, and recycled cooking greases. These feedstocks shall be referred to as biomass oils. The compound of interest contained in biomass oils is triacylglycerol (triglyceride in common usage). Most biomass oils contain about $95 \%$ triglycerides with small amounts of phosphatides, sterols, antioxidants, and other minor compounds. Triglycerides are composed of three long hydrocarbon chains called fatty acids (containing 6 to 24 carbons) with carboxyl ends attached to a glycerol molecule. Triglycerides are glycerol esters of fatty acids. When the fatty acids become disconnected from the glycerol backbone, they are called fatty acids or free fatty acids depending on the audience.

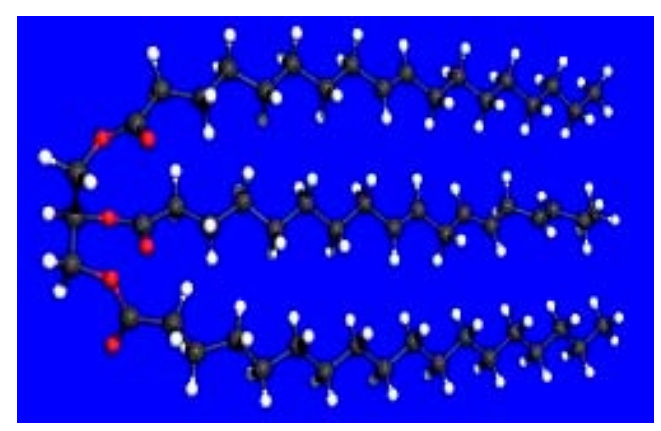

Figure 2. Triglyceride Molecule

As we shall see, biomass oils can displace imported petroleum. The key questions with respect to this achievement are:

\footnotetext{
${ }^{1}$ OBP also has goals specific to technology development in sugars and syngas that are not relevant to this discussion.
} 
- How much petroleum can be displaced in the short run? In the long run?

- At what cost?

- Can the costs be reduced?

- What are the technical barriers limiting market penetration?

- What are the technical barriers limiting supply of biomass oils?

- What coproduct R\&D would move the industry along, which coproduct investments won't?

- What are the policy needs?

- What are the benefits?

- What kind of program, if any, should OBP or EERE invest in?

Biorefinery technology can improve the income of firms that produce energy products combined with biobased coproducts. They do this by producing a variety of high value products in addition to the typically low value fuels. Most of a petroleum refiner's profits come from $10 \%$ of the barrel of petroleum oil that is used to produce high value petrochemicals, while the low value bulk fuels pay for the feedstock cost. This approach allows investors in petroleum refineries to earn higher returns on their invested equity than they would without the petrochemical product lines.

By applying this model to biomass biorefineries, we create drivers to create and expand the industry. The high risk of new technology, new markets, or both, increases the required rate of return investors need to see from a project to compensate for the risk of loss. Fuel markets are notoriously low value, fungible bulk goods with very narrow profit margins - frequently less than 0.25 cents per gallon. New fuels competing in the low value bulk fuel markets cannot provide a high enough rate of return to compensate investors for the risk involved. By adding biobased products to the product lines, it may be possible to raise the rate of return to the point where investors will be willing to invest in this risky new technology. This strategy presumes that the fuel price covers its production cost.

Higher rates of return attract investors and lead to expanded capacity. Profits generated by the biobased fuels may encourage more investment, more facilities, and eventually a larger biofuel supply. Thus, biomass biorefineries need biobased coproducts to succeed in the fuels industry.

One point to note is that biorefinery technology does not reduce the production cost of fuels. Those fuels must still be sold at a price that covers the feedstock and whatever share of the capital and processing costs are attributable to the fuel. If that is not the case, the fuel portion of this industry will not expand, only the product lines that add to the bottom line and improve investor's returns will be expanded in the next generation of plants. If the biomass fuel's production cost is higher than the price of the competing petroleum fuel, incentives will be necessary to market the fuel at a price that the public accepts. If incentives are offered, they must be offered in a manner that promotes industry stability, ensuring at least a five-year window in which capital improvements can be paid off.

The oleochemical industry has established commercial biorefineries for biomass oils. This OBP goal is more suitable for immature or emerging technology — biomass sugars and syngas. The 
primary goals of the biomass oil R\&D project are to reduce fuel and feedstock production costs and expand oil supply.

Biomass oil biorefineries, better known as oleochemical plants, are mature technologies that consumed 2.6 billion pounds of biomass oils and produced almost 4 billion pounds of oil-derived products in the United States in 2001. ${ }^{2}$ The earliest biorefineries were established before the United States Civil War and produced soaps, detergents, lubricants, solvents, and explosives among other minor products. Proctor and Gamble is a classic example of a biomass oil biorefinery. A wide variety of biomass oils are purchased based on their price and composition, and a large number of industrial and consumer goods are produced. The Chemical Economics Handbook (SRI International) has several useful chapters that describe this industry in detail including: Fats and Oils Industry Overview (2001), Natural Fatty Acids (2002), and Glycerin (2003).

Biomass oils are either hydrolyzed into fatty acids and glycerol, or they are converted into fatty acid methyl esters and glycerol. The fatty acids or esters are platform chemicals that become the basic building blocks for a complex array of derivative chemical technologies that produce high value products. Methyl esters are one of the possible biomass oil fuels that can be used to replace diesel fuel, better known as biodiesel.

Current methyl ester technology is nearly 90 years old, can use any feedstock, is continuous, and can attain yields of $99.7 \%$ or better (fatty acid conversion to esters). The byproduct glycerol has traditionally been a high value product with minimal chemical modification. Total production costs, net of feedstocks, for modern large-scale methyl ester plants (30 to 50 million gallons per year) are about 30 cents per gallon of ester product, which includes capital, interest, depreciation, and rate of return. There are many ways to produce methyl esters but none of them reduce production cost reductions significantly because the bulk of total production cost is feedstock cost.

Because the production costs of biodiesel exceed the market prices of the distillate fuels they displace, the expansion of methyl ester production is dependent on incentives. Oleochemical manufacturers would rather convert the esters into higher value products, and within this industry sector, methyl ester capacity will only grow as demand for the higher value coproducts grow. Most of the new methyl ester capacity has been established overseas where new feedstock production and demand for oleochemical products are expanding and feedstocks are less expensive.

As a result of its mature industry status, oleochemical plants produce a wide array of biobased products. While it might be attractive for OBP to invest in new oleochemical technology to meet their biobased product goals, there is little rational for that investment. An investment in oleochemical technology will do little to change the overall rate of return for the industry; it will not make methyl esters fuels less expensive, and it is not clear that the oleochemical industry lacks the technical or economic resources to support investments in their own industry. Public policy will do more for this industry segment vis-à-vis the petrochemical industry where the two

\footnotetext{
${ }^{2}$ Appendix A presents an overview of the oleochemical industry, its platform compounds, derivative markets, and key research initiatives.
} 
compete. Biobased purchasing programs and incentives can increase demand for oleochemicals, particularly where they compete with petroleum-based products.

Within the biomass oil industry there are groups of firms that may benefit from biorefinery technology. For example, most new biodiesel firms do not produce common oleochemical derivatives from their methyl esters. They do not produce byproducts from their glycerol slipstreams. Their limited diversification into simple methyl ester markets (solvents, lubricants) leaves them financially dependent on biofuel incentives. Another group of firms with limited biorefinery technology is the feedstock producers - the oilseed crushing mills and the rendering plants. Although it's logical for these firms to diversify into downstream technology, such as oleochemicals or protein extracts (biobased products from the coproduct protein meals), most do not.

What is needed to alter the circumstances surrounding these undiversified firms is not necessarily investment in coproduct or biorefinery R\&D per se, but education on the potential benefits of biorefinery technology and product diversity. Cargill and ADM have shown recent interest in developing novel fatty acid products. Their interest may stem from recent education on the benefits of sugar and ethanol biorefinery benefits. Federal funding is not necessary to support these firms' entry into the oleochemical industry, since traditional profit and risk management offer sufficient motivation already.

OBP and EERE do not develop or recommend public policy. However, what has been missing in the development of the biomass oil industry, with respect to energy issues, is an open debate on the best approach to maximizing petroleum displacement with biomass oils. Research and development are only a subset of public policy tools, and when there is a vacuum in the public policy arena, the most efficient use of R\&D is left to chance and the lobbying efforts of special interest groups. This report provides an analysis to bridge that gap. Approaches to displacing petroleum, maximizing biomass oil supply, reducing costs, and improving product and fuel performance will be discussed from both a technical as well as a public policy perspective in this analysis.

There is a tremendous volume of technical, market, and political information available in the public literature on every one of the topics raised in this report. Key issues from a number of large industrial segments of our society are integrated in this analysis: petroleum distillation and marketing, petroleum fuel quality and performance, diesel engine technology, air quality policies, farming, livestock production, oil seed crushing, rendering and oleochemical production. This analysis distills the key issues down to the essential topics necessary to evaluate the questions raised in this report. However, this analysis is not a substitute for a comprehensive study on any one of the topics or issues identified. The interested reader should explore specific literature sources for a detailed study of any of the issues raised in this study. 


\section{BIOMASS OIL AND DISTILLATE FUELS}

Biomass oils, and their derivative compounds such as biodiesel, have successfully displaced various grades of petroleum distillates and may be suitable for petroleum refining.

\subsection{Distillates Fuels}

Distillates are the cuts from a barrel of crude oil that have higher boiling points than most gasoline blend stocks but lower boiling points than heavy residual fuels (Figure 2). Roughly $33 \%$ of a barrel of crude is transformed into distillate fuels (Figure 3). For this discussion, the term "petroleum distillates" will include kerosene, diesel, heating oil, fuel oil, and jet fuel, unless a specific fuel grade is called out.

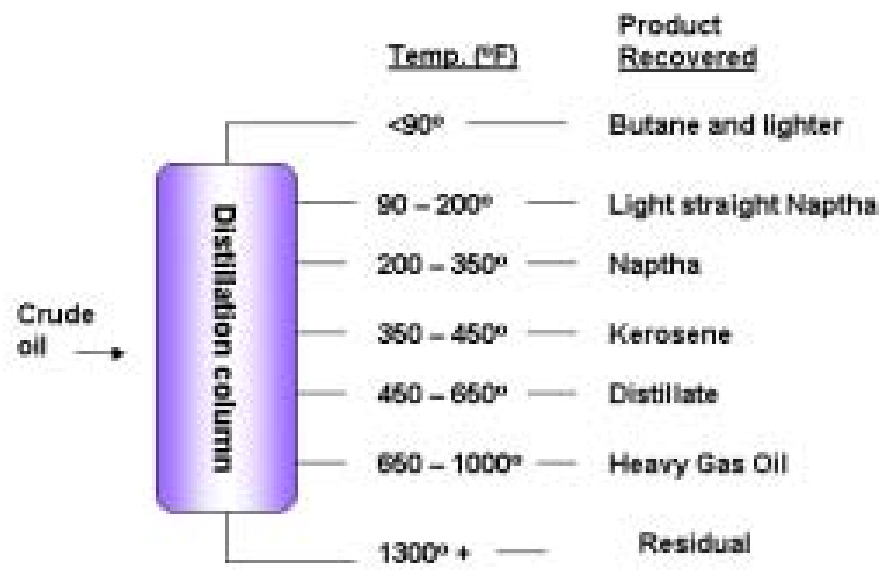

Figure 3. Crude Oil Distillation: The first step.

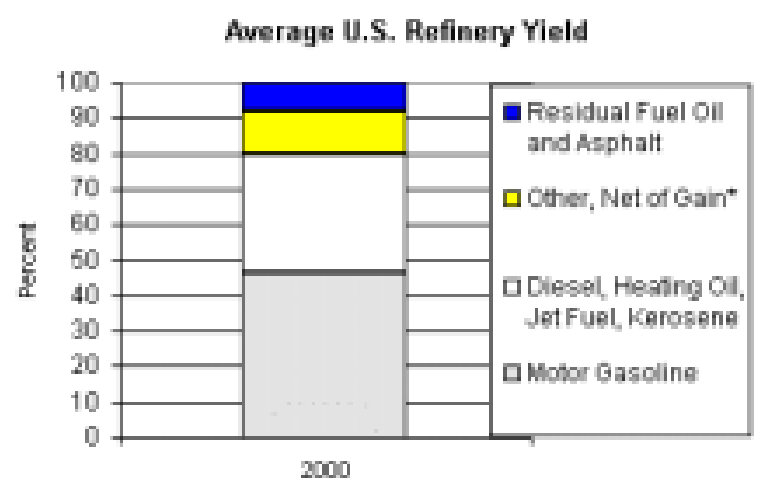

Figure 4. Average United States Refinery Yield, 2000. ${ }^{3}$

\footnotetext{
${ }^{3}$ DOE EIA, Oil Market Basics, http://www.eia.doe.gov/pub/oil_gas/petroleum/analys is_publications/oil_market_basics/default.htm.
} 
Various grades of distillates are used as boiler fuels, heating oil, aviation fuel, and diesel for marine, locomotive, military, forestry, mining, construction, farming, aircraft, and electricity generation. Highway use, which covers all transportation on public roads, represents about half of all distillate demand. The remaining markets are typically small. The size of the distillate market is about 4 thousand barrels per day, or 58 billion gallons per year (Table 2). Baring any supply or price shocks, distillate demand should grow to about 80 billion gallons per year by 2025 .

The ease of displacing a petroleum distillate fuel with a biomass oil fuel depends on the application, fuel quality, performance, and price. Several different technologies may be used by any one application. For example, electricity can be generated by a fuel boiler, a compression ignition (CI) engine, or a turbine. A technology may be operated on one or more distillate fuels, although specific equipment may be limited to a subset of fuels.

The American Society of Testing and Materials (ASTM) sets fuel grade standards for petroleum distillates and biomass fuel. The Environmental Protection Agency (EPA) sets emission standards for engines used in transportation while states regulate stationary applications. So the selection of a fuel must meet the performance needs of the engine, fuel quality standards, emission standards, and cost constraints. Cost constraints are influenced by fuel energy content and equipment efficiency on that fuel, the price of the fuel, and any additional maintenance costs and any loss of equipment life that a new fuel causes. 
Table 2. United States Distillate Fuel Demand Forecast by End Use Segment ${ }^{4}$

\begin{tabular}{|c|c|c|c|c|c|}
\hline Mil gal/yr & 2002 & 2005 & 2010 & 2015 & CAGR* \\
\hline Residential & 6,493 & 7,015 & 6,791 & 6,493 & $0.00 \%$ \\
\hline On-Highway & 33,371 & 37,437 & 45,140 & 51,509 & $3.40 \%$ \\
\hline Freight Trucks & 30,078 & 33,323 & 39,470 & 44,456 & $3.10 \%$ \\
\hline Intercity Bus & 280 & 285 & 299 & 306 & $0.70 \%$ \\
\hline Transit Bus & 726 & 738 & 774 & 791 & $0.70 \%$ \\
\hline $\begin{array}{l}\text { Light-Duty } \\
\text { Vehicle }\end{array}$ & 1,438 & 2,226 & 3,693 & 5,032 & $10.10 \%$ \\
\hline School Bus & 849 & 863 & 905 & 925 & $0.70 \%$ \\
\hline Commercial & 3,358 & 10,896 & 3,582 & 3,657 & $0.70 \%$ \\
\hline Industrial & 8,060 & 8,284 & 9,030 & 9,627 & $1.40 \%$ \\
\hline Freight Rail & 3,674 & 3,745 & 4,031 & 4,208 & $1.00 \%$ \\
\hline Intercity Rail & 126 & 133 & 146 & 160 & $1.80 \%$ \\
\hline Commuter Rail & 200 & 210 & 232 & 253 & $1.80 \%$ \\
\hline Utilities & 448 & 597 & 821 & 821 & $4.80 \%$ \\
\hline Domestic Shipping & 1,819 & 1,872 & 2,019 & 2,143 & $1.30 \%$ \\
\hline $\begin{array}{l}\text { International } \\
\text { Shipping }\end{array}$ & 373 & 388 & 391 & 394 & $0.40 \%$ \\
\hline Military & 826 & 886 & 895 & 938 & $1.00 \%$ \\
\hline Total Diesel & 58,746 & 71,462 & 73,078 & 80,202 & $2.40 \%$ \\
\hline
\end{tabular}

\subsubsection{Distillate Applications}

Diesel equipment falls into three basic categories: compression ignition (CI) engines, boilers, and turbines. A boiler sprays fuel through one or more nozzles that burns as open air flames to heat air or water for steam, power, and electricity. CI engines compress the fuel in closed chambers in an oxygen rich environment until it autoignites in a small explosion, creating power that moves pistons to provide mechanical energy. Sometimes, the mechanical power is transformed directly into electricity (power generators, locomotives). In a turbine the incoming air is compressed before being fed into the combustion chamber where the fuel injectors are located. The heat generated by the combustion of the pressurized fuel/air mixture expands the air and forces it through a set of blades or vanes that spin to produce the power or electricity. Equipment design parameters determine the desired fuel quality and fuel quality in turn affects the performance of the equipment, maintenance schedules, and durability of the equipment.

\footnotetext{
${ }^{4}$ Compound annual growth rate

Source: Energy Information Administration. Annual Energy Outlook 2003 with Projections to 2025. Report \#: DOE/EIA-0383(2003). January 9, 2003
} 
To some extent, original engine manufacturers (OEMs) have designed specific engines for biomass oil fuels, such as biodiesel or straight vegetable oil (SVO). However, the diesel industry uses many types of engines, from small to large, in a wide variety of applications. One or two engines designed for biomass oil fuels do not make a market for the fuel. The implicit goal of DOE biofuels R\&D has been to develop a fuel with the potential to become mainstream - a fungible national fuel. Widespread manufacturing of dedicated biomass oil engine technology depends on the ultimate supply potential of biomass fuels.

At this point in time, OEMs and other policy makers believe that biomass oils are supply limited (up to $5 \%$ of the distillate pool) and therefore most strategies revolve around blending biomass oils into the distillate supply rather than design optimized engines for biomass oils. More detail on biomass oil supplies is presented in Chapter 3.

\subsubsection{Distillate Standards and Grades}

ASTM D-975 describes highway diesel characteristics and ASTM D 396 describes heating oil and boiler fuel characteristics (also called fuel oils). Fuel quality standards are based on the performance needs of types of technology and equipment design and not on the feedstock characteristics used to make the fuel. A fuel standard does not always include all the important characteristics of a fuel, but only those that the ASTM technical committee has a consensus on. For example, storage stability and lubricity are not ASTM D 975 criteria yet. Users can combine the ASTM standard with personal criteria to define specific fuel performance standards.

An ASTM standard generally covers several grades of fuel. For example, No. 1 and No. 2 highway diesel are described in ASTM D 975. Kerosene and No. 2 through No. 6 fuel oils are described in ASTM D 396. Grades within a standard generally describe the range of distillates appropriate for specific uses.

Lighter distillates include jet fuel, kerosene and No. 1 highway diesel. They are valued for their low freezing points and low sulfur contents. JP8 is a military fuel that is closer to kerosene than No. 2 diesel whose purpose is to replace the various grades of distillate needed by military equipment (including aircraft) with one uniform grade. Midrange distillates include No. 2 diesel and No. 2 heating oil. These fuels have slightly higher energy than the lighter distillates and slightly higher freezing temperatures. Sulfur content varies with the application. Within the No. 2 diesel category there are separate grades for EPA highway diesel (less than 500 ppm sulfur), Ultra Low Sulfur Diesel (ULSD, less than 15 ppm sulfur), and off-road diesel (up to 5,000 ppm sulfur). Diesel containing 500 ppm sulfur or less are "low sulfur" fuels. Heavy distillates include No. 3 through No. 6 fuel oils that are typically institutional and industrial boiler fuels, and are also used in shipping and electric generation. The heavy distillates are typically high in sulfur and freeze at relatively high temperatures. They can be semi-solid to solid at winter ambient temperatures. When it is important to distinguish a specific grade of diesel, this report will do so. 
Table 3. Supplier Monthly Sales Volume of Distillate Fuel Oils and Kerosene, 1,000 Gallons/day

\begin{tabular}{|c|c|c|c|c|c|c|}
\hline \multirow[t]{3}{*}{ Month } & \multirow[t]{3}{*}{ Kerosene } & \multirow{3}{*}{$\begin{array}{c}\text { No. } 1 \\
\text { Distillate }\end{array}$} & \multicolumn{3}{|c|}{ No. 2 Distillate } & \multirow{3}{*}{$\begin{array}{c}\text { No. } 4 \\
\text { Fuel } \\
\text { Oil }\end{array}$} \\
\hline & & & \multirow{2}{*}{$\begin{array}{l}\text { No. } 2 \\
\text { Fuel Oil }\end{array}$} & \multicolumn{2}{|c|}{ No. 2 Diesel Fuel } & \\
\hline & & & & $\begin{array}{l}\text { Low- } \\
\text { Sulfur }\end{array}$ & $\begin{array}{l}\text { High- } \\
\text { Sulfur }\end{array}$ & \\
\hline Oct 2003 & $2,317.7$ & $1,587.1$ & $27,158.7$ & $115,375.4$ & $21,137.8$ & 543.6 \\
\hline Sept 2003 & $1,713.3$ & $1,083.9$ & $23,150.0$ & $112,378.7$ & $18,961.4$ & 386.8 \\
\hline Oct 2002 & $2,110.5$ & $1,860.0$ & $26,888.9$ & $110,188.6$ & $20,384.8$ & 472.9 \\
\hline
\end{tabular}

Biomass oil fuels do not meet petroleum fuel standards. Within a standard there are a number of test methods with limits or thresholds and biomass fuels often fail one or more of those tests. Biomass oil fuels typically exceed limits on fuel viscosity, distillation range or T90 boiling temperature, carbon residue, and cold flow. Other fuel quality differences that are frequent concerns include: oxidative stability, acid number, water and sediments, and content of minor compounds. Because biomass oils also come in various grades depending on feedstock, pretreatment, and processing technology, no blanket statements can be made about quality differences. Blending biomass oil fuels with petroleum fuels can minimize the differences seen with pure fuels, but blends can also fail one or more of the test limits depending on the blend level.

Typically a biomass oil fuel will target a specific grade of distillate that has characteristics close to those of the biofuel. Thus, designing biofuels for the distillate market requires the designer to target specific equipment, segmented markets, and specific varieties of distillate fuels.

\subsubsection{Fuel economy}

Biomass oils and their chemical derivatives, such as biodiesel have excellent energy content (Figure 5). The energy content of petroleum distillates and biomass oil fuels are close enough that fuel economy issues are minimized with blends up to $20 \%$, which are the most common ways of introducing biomass oils into the marketplace. ${ }^{5}$ For example, a blend of $20 \%$ biodiesel with $80 \%$ No. 2 diesel (B20) has $98 \%$ of the energy content of No. 2 diesel. A blend of 5\% biodiesel has $99.5 \%$ of the displaced fuel's energy content. In higher blend levels and for neat (pure) biomass oil fuels, fuel economy penalties become economic variables in substitution decisions. Power and torque suffer in proportion to the energy content of the fuels or blends.

\footnotetext{
${ }^{5}$ One pound of biodiesel contains 16,000 Btus compared to 18,3000 Btus in one pound of No. 2 diesel fuel (biodiesel has $12.5 \%$ less energy on a Btu/lb basis). However, one gallon of biodiesel contains 118,170 Btus compared to 129,050 Btus for a gallon of diesel fuel (biodiesel has $8 \%$ less energy on a gallon basis). Biodiesel has a higher fuel density (0.88) compared to No. 2 diesel (0.83) that accounts for the differences shown in the two measurements of energy content.
} 


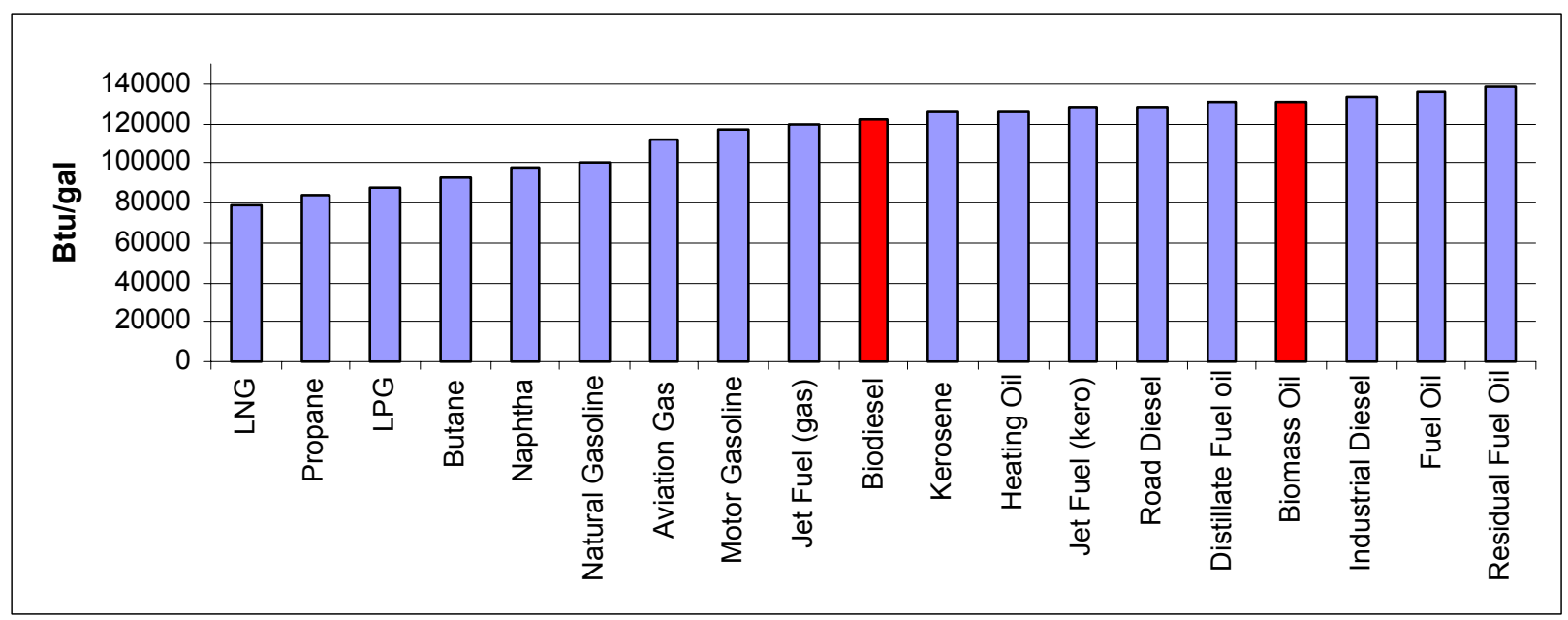

Figure 5. Energy Content of Petroleum Fuels and Biomass Oil Fuels

\subsubsection{Prices}

Distillates are inexpensive to produce, adding approximately $15 \%$ to the cost of crude oil. ${ }^{6}$ Low sulfur diesel fuels may cost more per gallon for processing as a result of sulfur removal and other fuel quality regulations. Retail prices paid by residential, commercial, industrial, and other retail end users are often higher, incorporating various transaction costs. Transaction costs include transportation and storage, distribution, insurance, and markup. Heating oil prices can include service contract fees for equipment maintenance and service calls. Distillate prices display considerable variation (Figure 6). Of course the underlying crude oil price plays a significant role as well.

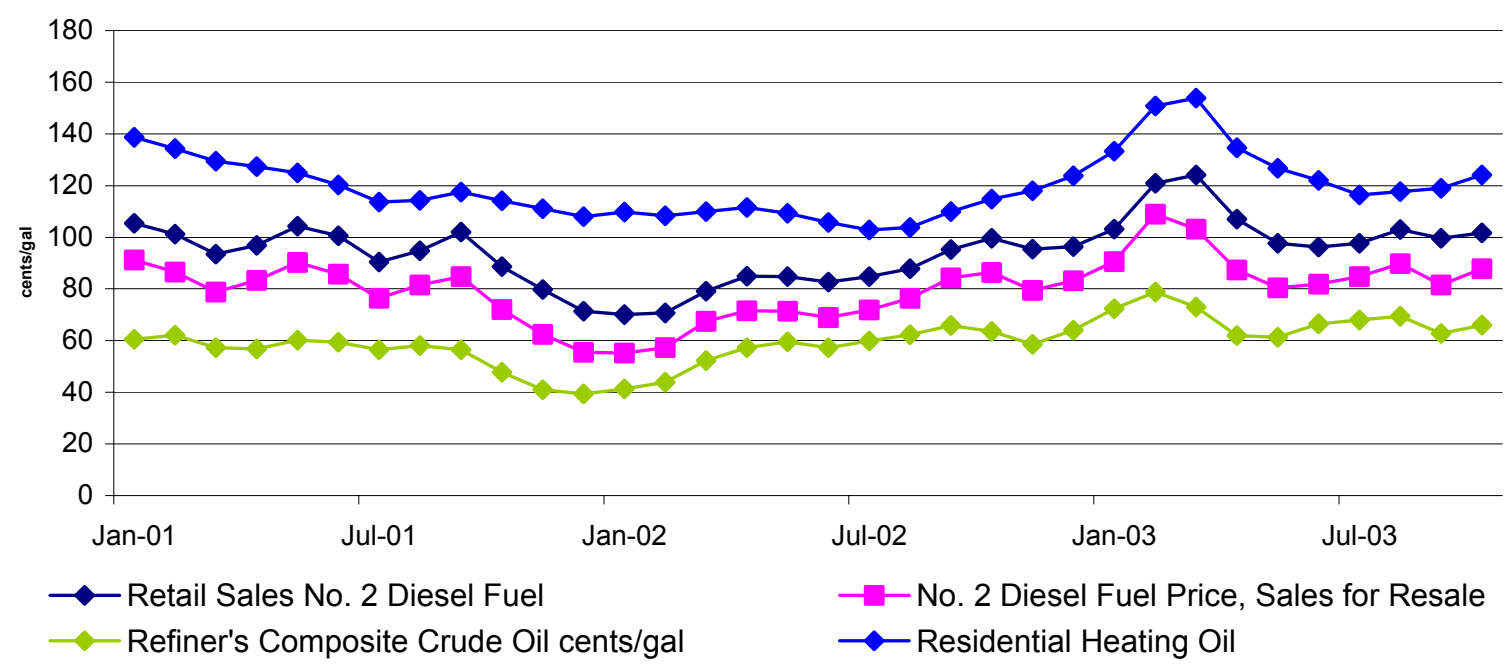

Figure 6. Petroleum and Distillate Fuel Prices, Excluding Taxes ${ }^{7}$

The prices of the lowest cost biomass oils - tallow, lard, and grease - compare favorably with wholesale distillate prices (sales for resale) and retail No. 2 diesel. However, it is clear that

${ }^{6}$ DOE/EIA-X048, September 2003. Residential Heating Oil Prices: What Consumers Should Know. Figure 1.

${ }^{7}$ DOE/EIA Petroleum Marketing Monthly, January 2004, Table 15 and 16. 
pricing cycles in diesel and biomass oil markets don't always favor substitution (Figure 7). Vegetable oil prices are quite a bit higher in general. The prices for soy and palm oil shown are the lowest priced vegetable oils on the market, all others (canola, sunflower, cottonseed, etc.) are typically higher. The prices shown in Figure 7 are generally increasing because biomass oil prices move through cycles. Prices bottomed out in 2001 and will probably peak in 2004. Prices are influenced by the supplies of soy and palm oil and animal fats, which in turn are influenced by the acres and yields of soy and palm, and the livestock production cycles in the beef market. In general, soy oil prices set the market for all other prices.

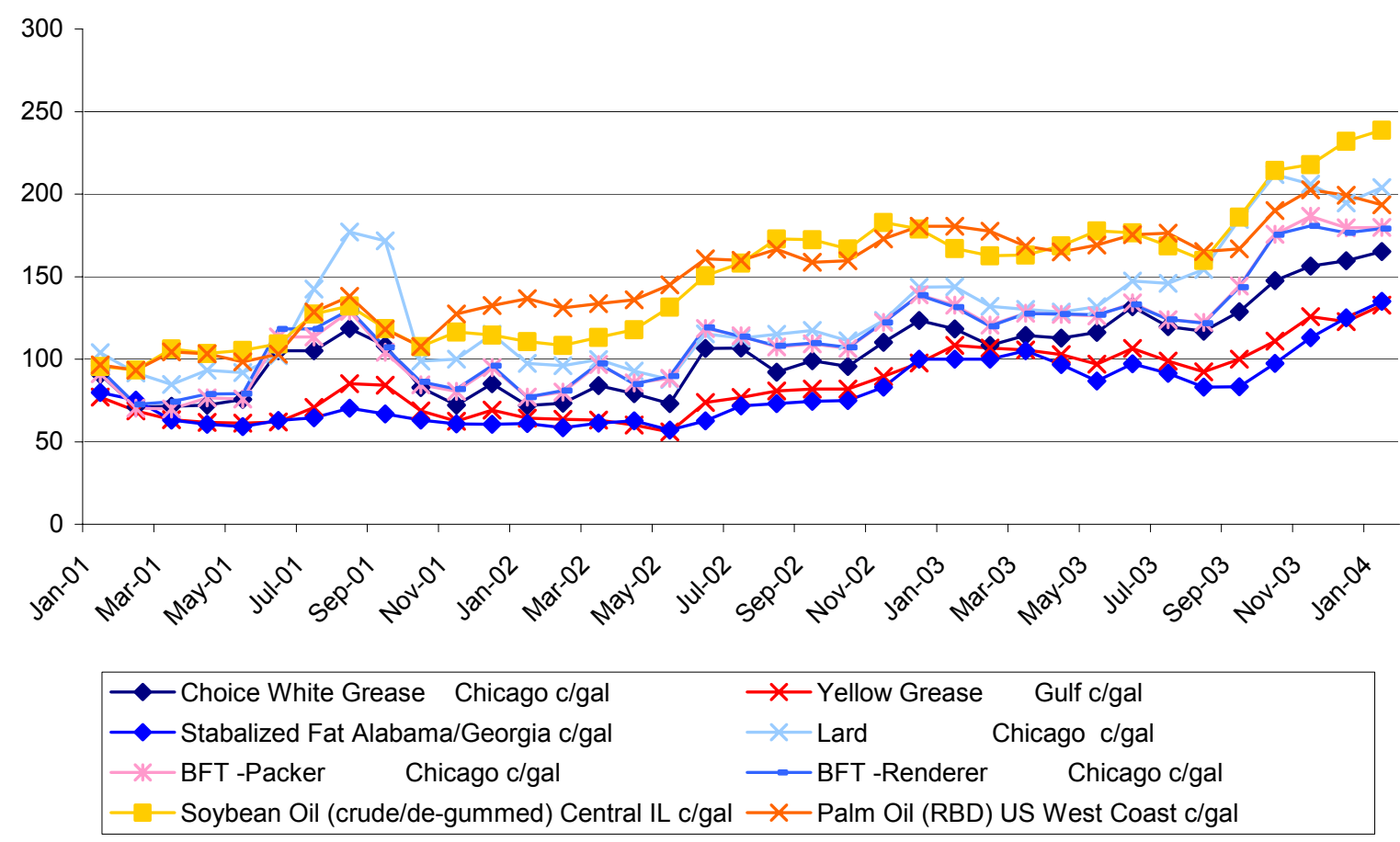

Figure 7. Recent Biomass Oil Prices ${ }^{8}$

When low cost biomass oil prices are compared with end user distillate prices (industrial, residential, retail), biomass oil fuels look attractive. However, this comparison does not adequately capture the transaction costs associated with storing, blending, and marketing biomass oil fuels and blends. The EIA estimates that transaction costs and mark up for ethanol, a fairly widespread renewable gasoline additive, averages 40 cents per gallon. Applying this estimate to biomass oils raises biomass oil retail prices above the retail prices of distillates. The average markup for distillates (based on highway transportation fuel) is 16.1 cents per gallon. ${ }^{9}$

Blends of biomass oil fuels with distillate fuels have more market acceptance because their price differential is less noticeable and more affordable. Consumers associate the biomass oil blends with premium values such as emission and global warming benefits, reduced environmental impact, recycling or agricultural support.

\footnotetext{
${ }^{8}$ Monthly data from The Jacobsen Publishing Company, February 24, 2004.

${ }^{9}$ DOE/EIA Annual Energy Outlook, 2004, Assumptions.
} 
Producing biodiesel from biomass oils can add 30 to 90 cents to the cost of feedstock biomass oils, depending mostly on the size of the facility, and to a lesser extent on the feedstock quality and biodiesel technology. Production costs shown in Figure 8 are based on a greenfield, 10 million gallon per year stand alone biodiesel plant, using monthly high-low feedstock costs from 2002 for soy oil, yellow grease (YG), and retail (before tax) No. 2 highway diesel. The numbers following the feedstock indicate percentage blend-B100 indicates the pure fuel, B20 indicates a $20 \%$ blend of biodiesel and No. 2 highway diesel, and B2 is a fuel that contains $2 \%$ biodiesel, all on a volumetric basis. All wholesale prices shown include markup but not taxes.

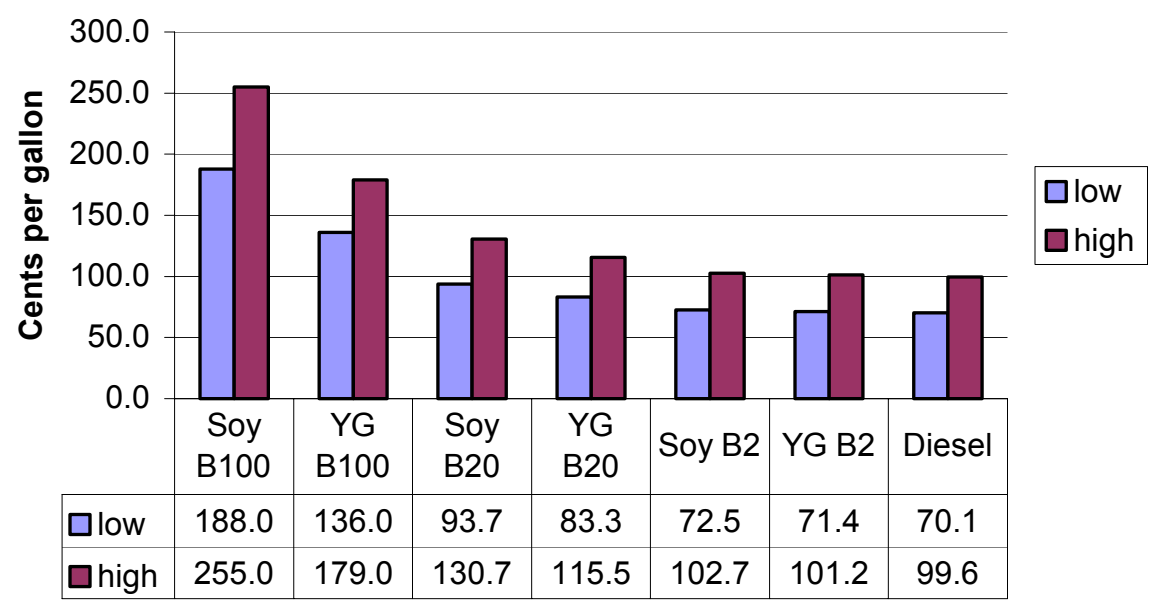

Figure 8. Retail (before tax) prices of Diesel No. 2, Biodiesel, and Blends

Biodiesel processing may improve the characteristics of biomass oils for $\mathrm{CI}$ engine applications but it raises fuel costs to uncompetitive levels except in the case of the lowest priced feedstocks. However, blends such as B20 or B2 appear to offer some reasonable competitive opportunities, narrowing price differentials to the point where consumers are willing to pay premium prices for a fuel with "premium" attributes. Biofuel consumers frequently recognize that biofuels offer social benefits difficult to capture in market pricing strategies.

Note that the prices shown above are before tax, and thus, tax incentives do not change the underlying economics unless the tax advantage exceeds the diesel excise tax per gallon, as in the case of the proposed 2004 Energy Bill. The next section will go into more detail on taxes and incentives.

\subsubsection{Taxes}

Both distillates and biomass oil fuels are subject to federal, state and local taxes. The type of tax varies with the two primary use categories - highway use and off-road use. Highway use includes fuel that is used in any type of self-propelled vehicle covered by 26CFR48.4041-8(b) used on any public road. ${ }^{10}$ There are exemptions for some types of uses such as school or intercity buses. Highway use is subject to federal, state, and local excise taxes and sometimes sales tax. Off-road use is subject to state and local sales or special use taxes only. Off-road, and

\footnotetext{
${ }^{10}$ See 26CFR48 (4-1-03 ed), all chapters, for further information.
} 
fuel for other exempt uses, must be clearly marked as nontaxable and dyed red ${ }^{11}$ once it is offered for sale as a fuel. ${ }^{12}$ Federal excise taxes on diesel fuel are $\$ 0.243$ per gallon. State excise taxes vary with a mean of approximately $\$ 0.22 /$ gal. Some states levy a sales tax on highway transportation fuels as well.

In the case of distillates, the firm offering the fuel for sale to the consumer is responsible for collecting and paying taxes to the responsible authorities. The taxes are embedded in the retail price of the fuel. Fuel blenders often pay the taxes due on blends of biomass oil fuels. Individual producer/users are responsible for paying the taxes themselves.

Some biomass fuels do not meet the definition of diesel fuel for diesel fuel taxation under 26CFR Part 48.4081-1(c)(2) because they contain less than 4\% paraffins, or they have a distillation range of 125 degrees or less, a Saybolt color number of 25 or less, and a sulfur content of less than $10 \mathrm{ppm}$. If the biomass oil fuel is blended with petroleum, then the fuel does not meet the exemptions and the fuel blend is taxable under 26CFR48.4081(b)(1). Pure biomass oil fuels, such as biodiesel or SVO, are exempt under 26CFR48.4081 but are taxed under 26CFR48.40824: "any liquid (other than taxable fuel) for use as a fuel." Distillates produced from biomass oils via traditional refining processes may be taxable as diesel fuel depending on the fuel characteristics.

Most incentives that target taxes, transaction costs, infrastructure costs, or production costs associated with biomass oil fuels have targeted biodiesel. Straight biomass oils are either excluded by defining the "qualified" fuel in the definition portion of the legislation, or included as a result of either vague or purposely broad language. Interested persons should carefully consider the definition of the fuel that qualifies for incentives.

The proposed 2004 Energy Bill would reduce federal excise taxes by 1 cent for every percent biodiesel in a blend if the biodiesel feedstock is made from first use ("virgin") vegetable oils or animal fats (equivalent to $\$ 1.00$ per gallon B100). Recycled feedstocks would be allowed 0.5 cents excise tax reduction per percent biodiesel blend ( $\$ 0.50$ per gallon B100). Off road and exempt users would be able to seek similar credits - Biodiesel Fuels Credit—on a per gallon basis through income tax credits, limited by Alternative Minimum Tax regulations.

Note that biodiesel costs are not reduced by the entire $\$ 1.00$ or $\$ 0.50$ per gallon, but by the difference between the incentive and the tax owed (Figure 9). Thus, soy B100 has a reduction of $\$ 0.757 /$ gal $=\$ 1.00$ per gallon incentive less $\$ 0.243$ in federal excise taxes. State taxes, transaction costs, and markup will all add to the costs shown below.

\footnotetext{
${ }^{11}$ 26CFR4082-1(b)

12 (e.g., methyl esters sold as an oleochemical intermediate chemical feedstock would be exempt, or methyl esters sold as a solvent would be exempt)
} 


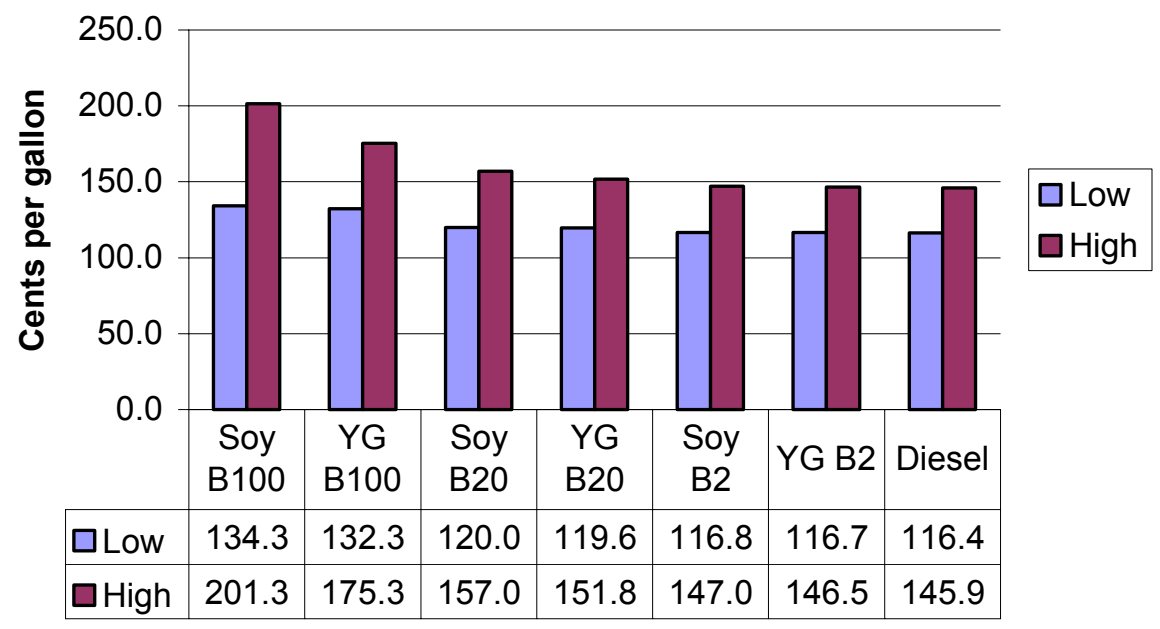

Figure 9. Biodiesel and Biodiesel Blend Prices Including Proposed Federal Excise Tax Incentives

Some states offer lower state excise or sales taxes or income taxes credits on the sale or production of biodiesel or biodiesel blends. Other state incentives include income tax credits for equipment or investments used to produce biodiesel, direct incentive payments on production levels or blending levels, incentives for specific uses such as intercity buses, or mandates the use of biodiesel fuel in state or local fleets. At least one state, MN, has mandated the use of a $2 \%$ biodiesel blend statewide by 2005 , subject to various provisions. State regulations change frequently, and with less fanfare than federal regulations, so the interested reader should seek the most up-to-date information from their Treasury department or other tax authorities.

As the cost of crude oil rises, the gap between the cost of the two fuels will narrow, although the two commodity prices don't always cycle in favorable ways. For example, in 2002 heating oil prices were high and biomass oil prices were low resulting in significant fuel substitution in the boiler markets and in B20 markets. In 2004, diesel fuel prices are high at the same time as biomass oil prices are reaching record highs, resulting in very little incentive for substitution.

Premium diesel fuels with biodiesel content may become a retail fuel for diesel automobile consumers, who tend to be predisposed toward diesel and typically purchase high-end automobiles (Mercedes, Volvo, etc.). Previous marketing campaigns for premium gasoline have left an indelible market, and these consumers tend to prefer premium diesel fuels as well. Well over $100 \mathrm{~B} 20$ retail stations have opened in the last four years nationwide. B100 is also sold into this market, although far fewer retail B100 facilities are available.

European tax policy favors biodiesel fuels. B100 is a commercial fuel in Germany and Austria where it is exempt from a tax of $\in 0.50$ per liter (roughly $\$ 2.27$ per United States gallon depending on the exchange rate). The tax exemption allows the more expensive biodiesel to be priced competitively against the heavily taxed diesel fuel. The European Commission is promoting a member-wide policy to implement $2 \%$ blends by 2005 , increasing to $5.75 \%$ by 2010 and to $20 \%$ by 2020 . Significant land use and agricultural subsidies are used to achieve these goals, in addition to the tax-exempt policy. 


\subsection{Biomass Oil Fuels}

The following sections provide a brief overview on the pros and cons of many of the biomass oil fuels being used in the United States. They are listed below for convenience:

- Biomass oil used directly in commercial and industrial boilers as substitutes for No. 2, No.4 and No. 6 fuel oils, also blends of the petroleum boiler fuels with biomass oils

- Biomass oil and blends of biomass oil and other distillates used in turbines

- Biomass oil and blends of biomass oil with No. 2 and No. 1 diesel (highway and off-road) used in compression ignition ("diesel") engines

- Biodiesel and blends of biodiesel and No. 2 heating oil in residential and commercial boilers as a substitute for No. 2 (including blends of No. 1 and No. 2)

- Biodiesel and blends of biodiesel and highway diesel fuels (No. 2, No. 1, ULSD, CARB, Fischer Tropsch, etc.) used in compression ignition (CI) engines

- Biodiesel and blends of biodiesel with off-road No. 2 or No. 1 diesel fuels in CI engines used-off road (farming, construction, electric generation, locomotives, shipping, etc.)

- Blends of biodiesel with aviation distillates in aircraft engines

- Agtane and other bio-distillates produced from biomass oils using modified refinery processes

- Other biomass oil derivatives used as fuel

\subsubsection{Biomass Oil Composition}

Before we continue with this discussion, we need to examine the differences between various biomass oils. Chapter 1 explained the basic structure of biomass oils; that each triglyceride molecule consisted of three long-chain fatty acids attached to a glycerol backbone.

The fatty acid chains are hydrocarbons, 6 to 26 carbons in length, with a carboxyl group attached at one end (Table 5). They are known by their chemical names, by common terminology and by abbreviating the number of carbons followed by the number of double bonds. You can also see abbreviations that identify which carbons the double bonds follow when variations occur.

Saturated fatty acids are structurally similar to their petroleum counter parts - paraffins (left side of Figure 10). Where they are not fully saturated, the degree of unsaturation (number of $\mathrm{C}=\mathrm{C}$ bonds) varies from 1 (olefins) to 5 double carbon bond sites (right side of Figure 10). When fatty acids are made into methyl esters, a methanol molecule is bonded to the carboxyl end of each fatty acid.

Feedstocks are characterized by the type and concentrations of fatty acids present (Table 6). Feedstocks are generally saturated, unsaturated, monounsaturated, or polyunsaturated which describes the majority of fatty acids present and their desirability for particular oleochemical applications. Feedstocks with similar compositions can be used interchangeably in processes designed for those compositions, depending on prevailing prices. Tallow, palm oil, and soy oil are the most common industrial feedstocks.

The perfect feedstock for biodiesel is one composed of $100 \%$ monounsaturated fatty acidC16:1, C18:1, C20:1 or C22:1. 


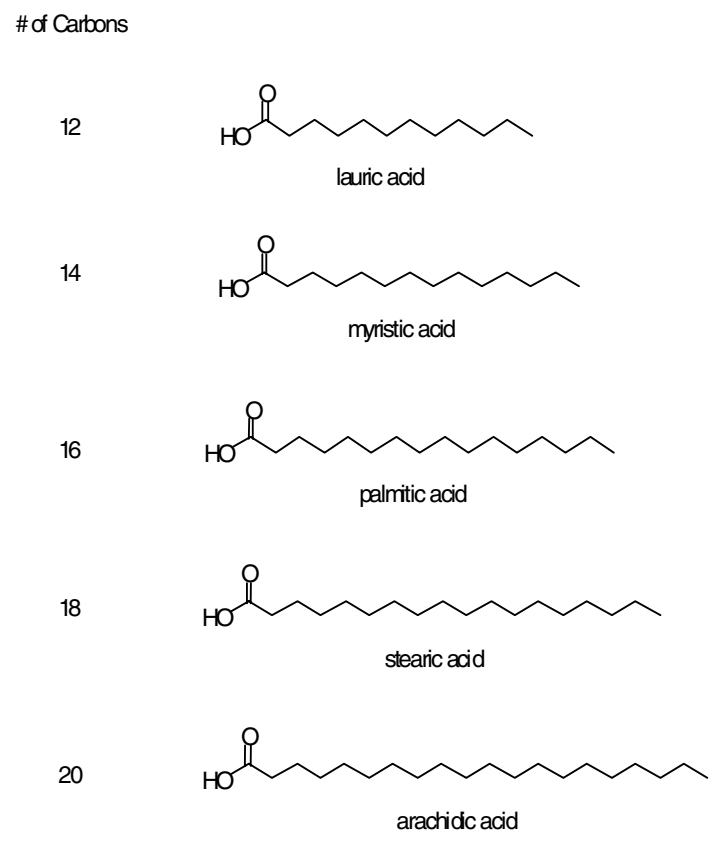

Figure 10. Selected fatty acid structures.

Fuel properties vary with fatty acid composition and the presence of minor compounds such as sterols, antioxidants, and phosphatides. Fatty acid composition has the most impact on the following fuel properties:

- Freezing point

- Oxidative stability

- Cetane number

- NOx emissions

Table 4 shows the relative impact of biomass oil fuel composition on fuel properties. Several recent NREL reports provide specific data on these and other properties for various feedstocks and fatty acid esters. ${ }^{13}$

Table 4. Biomass Oil Composition and Impact on Fuel Properties

\begin{tabular}{|l|l|l|l|}
\hline & Saturated & Monounsaturated & Polyunsaturated \\
\hline Cetane Number & High & Medium & Low \\
\hline Could Point & High & Medium & Low \\
\hline Stability & High & Medium & Low \\
\hline NOx Emissions & Reduction & Medium increase & Large increase \\
\hline
\end{tabular}

\footnotetext{
${ }^{13}$ Graboski et al., February 2003. The Effect of Biodiesel Composition on Engine Emissions from a DDC Series 60 Engine. NREL/SR-510-31461 and Kinast, J.A. March 2003. Production of Biodiesel from Multiple Feedstocks and Properties of Biodiesel and Biodiesel/Diesel Blends, NREL/SR-510-31460.
} 
Table 5. Structural Formula, Melting and Boiling Points for Fatty Acids and Fatty Acid Methyl Esters

\begin{tabular}{|c|c|c|c|c|c|c|}
\hline \multirow{2}{*}{$\begin{array}{l}\text { Fatty Acid } \\
\text { Name }\end{array}$} & \multirow{2}{*}{$\begin{array}{l}\text { No. Of } \\
\text { Carbons \& } \\
\text { Double } \\
\text { Bonds }\end{array}$} & \multirow{2}{*}{$\begin{array}{l}\text { Chemical Structure } \\
\text { (= denotes double bond placement) }\end{array}$} & \multicolumn{2}{|c|}{ Fatty Acids } & \multicolumn{2}{|c|}{ Methyl Esters } \\
\hline & & & $\begin{array}{l}\text { Melting } \\
\text { Point, }{ }^{\circ} \mathrm{C}\end{array}$ & $\begin{array}{l}\text { Boiling } \\
\text { Point, }{ }^{\circ} \mathrm{C}\end{array}$ & $\begin{array}{l}\text { Melting } \\
\text { Point, }{ }^{\circ} \mathrm{C}\end{array}$ & $\begin{array}{l}\text { Boiling } \\
\text { Point, }^{\circ} \mathrm{C}\end{array}$ \\
\hline Caprylic & $\mathrm{C} 8$ & $\mathrm{CH}_{3}\left(\mathrm{CH}_{2}\right)_{6} \mathrm{COOH}$ & 16.5 & 239 & -40 & 193 \\
\hline Capric & $\mathrm{C} 10$ & $\mathrm{CH}_{3}\left(\mathrm{CH}_{2}\right)_{8} \mathrm{COOH}$ & 31.3 & 269 & -18 & 224 \\
\hline Lauric & $\mathrm{C} 12$ & $\mathrm{CH}_{3}\left(\mathrm{CH}_{2}\right)_{10} \mathrm{COOH}$ & 43.6 & 304 & 5.2 & 262 \\
\hline Myristic & $\mathrm{C} 14$ & $\mathrm{CH}_{3}\left(\mathrm{CH}_{2}\right)_{12} \mathrm{COOH}$ & 58.0 & 332 & 19 & 295 \\
\hline Palmitic & $\mathrm{C} 16: 0$ & $\mathrm{CH}_{3}\left(\mathrm{CH}_{2}\right)_{14} \mathrm{COOH}$ & 62.9 & 349 & 30 & 415 \\
\hline Palmitoleic & $\mathrm{C} 16: 1$ & $\mathrm{CH}_{3}\left(\mathrm{CH}_{2}\right)_{5} \mathrm{CH}=\mathrm{CH}\left(\mathrm{CH}_{2}\right)_{7} \mathrm{COOH}$ & 33.0 & -- & 0 & -- \\
\hline Stearic & C18:0 & $\mathrm{CH}_{3}\left(\mathrm{CH}_{2}\right)_{16} \mathrm{COOH}$ & 69.9 & 371 & 39.1 & 442 \\
\hline Oleic & C18:1 & $\mathrm{CH}_{3}\left(\mathrm{CH}_{2}\right)_{7} \mathrm{CH}=\mathrm{CH}\left(\mathrm{CH}_{2}\right)_{7} \mathrm{COOH}$ & 16.3 & -- & -19.9 & -- \\
\hline Linoleic & $\mathrm{C} 18: 2$ & $\mathrm{CH}_{3}\left(\mathrm{CH}_{2}\right)_{4} \mathrm{CH}=\mathrm{CHCH}_{2} \mathrm{CH}=\mathrm{CH}\left(\mathrm{CH}_{2}\right)_{7} \mathrm{COOH}$ & -5.0 & -- & -35 & -- \\
\hline Linolenic & $\mathrm{C} 18: 3$ & $\mathrm{CH}_{3}\left(\mathrm{CH}_{2}\right)_{2} \mathrm{CH}=\mathrm{CHCH}_{2} \mathrm{CH}=\mathrm{CHCH}_{2} \mathrm{CH}=\mathrm{CH}\left(\mathrm{CH}_{2}\right)_{7} \mathrm{COOH}$ & -11.0 & -- & -- & -- \\
\hline Arachidic & $\mathrm{C} 20: 0$ & $\mathrm{CH}_{3}\left(\mathrm{CH}_{2}\right)_{18} \mathrm{COOH}$ & 75.2 & -- & 50 & -- \\
\hline Eicosenoic & $\mathrm{C} 20: 1$ & $\mathrm{CH}_{3}\left(\mathrm{CH}_{2}\right)_{7} \mathrm{CH}=\mathrm{CH}\left(\mathrm{CH}_{2}\right)_{9} \mathrm{COOH}$ & 23.0 & -- & -15 & -- \\
\hline Behenic & $\mathrm{C} 22: 0$ & $\mathrm{CH}_{3}\left(\mathrm{CH}_{2}\right)_{20} \mathrm{COOH}$ & 80.0 & -- & 54 & -- \\
\hline Eurcic & $\mathrm{C} 22: 1$ & $\mathrm{CH}_{3}\left(\mathrm{CH}_{2}\right)_{7} \mathrm{CH}=\mathrm{CH}\left(\mathrm{CH}_{2}\right)_{11} \mathrm{COOH}$ & 34.0 & -- & -- & -- \\
\hline
\end{tabular}


Table 6. Weight Percent of Fatty Acids in Fat and Oil Feedstocks

\begin{tabular}{|c|c|c|c|c|c|c|c|c|c|c|c|c|c|}
\hline $\begin{array}{l}\text { Fatty Acid } \\
\text { Fat or Oil }\end{array}$ & C8:0 & C10:0 & C12:0 & C14:0 & C16:0 & C16:1 & C18:0 & C18:1 & C18:2 & C18:3 & $\begin{array}{l}\text { C20:0 } \\
\text { C22:0 }\end{array}$ & $\begin{array}{l}\text { C20:1 } \\
\text { C22:1 }\end{array}$ & Other \\
\hline $\begin{array}{l}\text { Yellow } \\
\text { Grease }\end{array}$ & & & & 1 & 23 & 1 & 10 & 50 & 15 & & & & \\
\hline Tallow & -- & -- & 0.2 & $2-3$ & $25-30$ & $2-3$ & $21-26$ & $39-42$ & 2 & -- & $0.4-1$ & 0.3 & 0.5 \\
\hline Lard & -- & -- & -- & 1 & $25-30$ & $2-5$ & $12-16$ & $41-51$ & $4-22$ & -- & - & $2-3$ & 0.2 \\
\hline Butter & $1-2$ & $2-3$ & $1-4$ & $8-13$ & $25-32$ & $2-5$ & $25-32$ & $22-29$ & 3 & -- & $0.4-2$ & $.2-1.5$ & $1-2$ \\
\hline Coconut & $5-9$ & $4-10$ & $44-51$ & 13-18 & $7-10$ & -- & $1-4$ & $5-8$ & $1-3$ & -- & -- & -- & -- \\
\hline Palm Kernal & $2-4$ & $3-7$ & $45-52$ & 14-19 & $6-9$ & $0-1$ & $1-3$ & $10-18$ & $1-2$ & -- & $1-2$ & -- & -- \\
\hline Palm & -- & -- & -- & $1-6$ & $32-47$ & -- & $1-6$ & $40-52$ & $2-11$ & -- & -- & -- & -- \\
\hline Safflower & -- & -- & -- & -- & 5.2 & -- & 2.2 & 76.3 & 16.2 & -- & -- & -- & -- \\
\hline Peanut & -- & -- & -- & 0.5 & $6-11$ & $1-2$ & $3-6$ & $39-66$ & $17-38$ & -- & $5-10$ & -- & -- \\
\hline Cottonseed & -- & -- & -- & $0-3$ & $17-23$ & -- & $1-3$ & $23-41$ & $34-55$ & -- & -- & $2-3$ & -- \\
\hline Corn & -- & -- & -- & $0-2$ & $8-10$ & $1-2$ & $1-4$ & $30-50$ & $34-56$ & -- & -- & $0-2$ & -- \\
\hline Sunflower & -- & -- & -- & -- & 6.0 & -- & 4.2 & 18.7 & 69.3 & 0.3 & 1.4 & -- & -- \\
\hline Soybean & -- & -- & -- & 0.3 & $7-11$ & $0-1$ & $3-6$ & $22-34$ & $50-60$ & $2-10$ & $5-10$ & -- & -- \\
\hline Rapeseed & -- & -- & -- & -- & $2-5$ & 0.2 & $1-2$ & $10-15$ & $10-20$ & $5-10$ & .9 & $50-60$ & -- \\
\hline Linseed & -- & -- & -- & 0.2 & $5-9$ & -- & $0-1$ & $9-29$ & $8-29$ & $45-67$ & -- & -- & -- \\
\hline Tung & -- & -- & -- & -- & -- & -- & -- & $4-13$ & $8-15$ & $72-88$ & -- & -- & -- \\
\hline
\end{tabular}


Most oilseeds contain their own natural antioxidants to protect the oil from degradation prior to sprouting. Some of the oil extraction and pretreatment processes can destroy some or all of the natural antioxidants or they can be removed and sold into high end vitamin markets. Some oil and biodiesel producers introduce synthetic antioxidants to provide protection.

Standards on biodiesel production require the removal of excess phosphatides, which can cause gum formation if present and the phosphorus content can deactivate catalysts on modern diesel engines.

\subsubsection{Unconverted Fats and Oils as Boiler Fuels}

Biomass oils are used straight or blended with No. 2, No. 4 or No. 6 boiler fuels in industrial boilers with only minor modifications to existing equipment and air quality permits. The practice intensifies when fossil fuel prices rise and/or biomass oil prices fall. Biomass oils freeze at relatively high temperatures, making them similar to No. 4 or No. 6 fuel oils, but without the sulfur content. Consistent use of biomass oils as boiler fuels may require some type of incentive, green fuel credit or other mechanism to drive demand (Table 7).

Boilers designed for heavy fuel oils typically contain some type of fuel preheating system. Boilers designed for No. 2 fuel oil that do not contain fuel heaters may be better off with blends of biodiesel (discussed shortly), which exhibits better cold weather properties than unconverted biomass oils. No EPA fuels registration under CFR $211 \mathrm{~b}$ is required for biomass oils (or chemical derivatives of biomass oils such as biodiesel) used in off-road applications. Substituting biomass oils for boiler fuel is limited by the price of biomass oils, which can exceed fuel oil prices in most years. Newcomers to this practice are somewhat limited by access to air quality permit data, which can be found through the Fats and Protein Research Foundation and its membership firms. Value added is limited to the price differential between the two fuels, sulfur reduction benefits, and other air quality benefits where available.

Table 7. Market Penetration Scenarios for Biomass Oils in Boiler Fuel Markets

\begin{tabular}{|l|c|c|c|c|}
\hline \multicolumn{1}{|l|}{$\mid$} & 2002 & 2005 & 2010 \\
\hline \hline Percentage blend & $5 \%$ & $5 \%$ & $5 \%$ \\
\hline \hline Market Penetration & 0 & $1 \%$ & $10 \%$ \\
\hline \hline Commercial boiler fuel, mil gal/yr B100 & 0 & 5 & 18 \\
\hline \hline Industrial boiler fuel, mil gal/yr B100 & 0 & 4 & 45 \\
\hline
\end{tabular}

\subsubsection{Biomass Oils as Highway Diesel Fuel}

Some people are using biomass oils fuels in CI engines. They call this fuel SVO for straight vegetable oil. Some consumers are using recycled greases or waste vegetable oils (WVO) in CI engines. There are a number of commercial retrofit kits available to the consumer, whose primary purpose is to heat the SVO prior to injection in order to reduce viscosity. ${ }^{14}$ There is a large body of research data that shows that SVO and blends of $20 \%$ or more SVO and diesel fuel

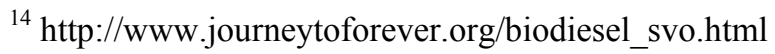


damage CI engines when used over long periods of time. ${ }^{15}$ Problems include: injector coking, ring sticking, diluted crankcase oil that led to premature gelling and oxidation, increased risk of total engine failure, and reduced fuel economy and power.

The practice persists because the damage is difficult to detect in the short run. Most short-term research projects are problem free and many consumers have used SVO without problems for as long as two years. Consumer motivation is based on the renewable nature of the fuel, global warming benefits, farm support, and economics, as users illegally avoid federal and state fuel taxes on SVO fuels.

There is a dearth of data for lower level blends $(<20 \%)$ and considerable interest in whether a $2 \%$ blend of vegetable oil with diesel fuel can be commercialized. Long term durability testing is the key. In recent fuel quality tests, a blend of 2\% soybean oil (Wesson) with $98 \%$ ULSD passed all standards in ASTM D 975 except for carbon residue. ${ }^{16}$ Further research may be warranted if low blends of biodiesel (B2) ${ }^{17}$ are commercialized. There are several benefits to using SVO as a $2 \%$ blend rather than biodiesel:

- Cheaper than biodiesel; no processing costs for transforming SVO into biodiesel

- No market glut of glycerol that results from biodiesel production

- More readily available

- SVO provides lubricity for ULSD

- $2 \%$ SVO could be a national fungible fuel coast to coast.

In order to commercialize low blends of SVO, even $2 \%$ blends, the following steps are required:

- Establish a fuel quality specification for SVO blendstock

- Conduct long-term durability trials on the target blend

- Conduct Tier I and Tier II health effects research for EPA registration

- Conduct logistical testing on SVO storage, blending, and stabilization additives to develop handling protocols.

Enough experience exists to show that fuel quality is a key issue to commercializing low blends of SVO even before conducting durability tests. SVO should have low free fatty acid contents, good iodine numbers (for storage stability, otherwise, should contain an antioxidant), and should be refined, degummed, and filtered.

The oil displacement potential of a $2 \%$ SVO blend may be limited by the problems that will be encountered by increasing the blend percent (e.g., going from $2 \%$ to $5 \%$ or $10 \%$ ). The problems that were encountered with blends of SVO were resolved by chemically modifying the fuel, transforming the triglycerides into methyl esters.

\footnotetext{
${ }^{15}$ Jones, S. and C. L. Peterson. 2002. Using Unmodified Vegetable Oils as a Diesel Fuel Extender: A literature review. BioEnergy 2002, Boise, Id.

http://www.uidaho.edu/bae/biodiesel/raw\%20vegetable\%20oils literature\%20review.doc

${ }^{16}$ SwRI Project number 1.08.05 06093.01.019, Final Report, NREL Subcontract JCM-2-32040-01, WO\#39

${ }^{17}$ The convention for describing blends of biodiesel is BXX where XX is the percentage of biodiesel by volume in a gallon of blended diesel fuel.
} 


\subsubsection{Pure Biodiesel (B100)}

Biodiesel was developed to resolve the problems identified with SVO. Transesterification reduced viscosity and cold flow, and eliminated coking, deposit formation, ring sticking, and the other durability problems encountered with SVO. Some of the early problems observed with biodiesel were traced to poor processing and contamination. An ASTM standard for biodiesel has reduced problems associated with quality control issues.

While B100 can be used in unmodified diesel engines and heating oil systems, significant technical and economic barriers restrict this practice to a handful of environmentally motivated consumers. Problems with B100 include material compatibility with seals, gaskets, and other fuel system components, cold weather freezing, storage stability, and NOx emissions exceeding $\mathrm{CI}$ engine certification levels. B100's technical problems (other than NOx emissions) can be minimized by retrofitting fuel system components, adding fuel system heaters, and using storage stability additives and biocides if necessary. Customer motivation for using B100 includes renewable content, reducing global warming emissions, reducing emissions of carbon-based compounds and air toxics, and other environmental benefits such as biodegradability and nontoxicity. B100 fuels are used in National Parks, sensitive waterways, and other locations where environmental or human health concerns are especially important (underground mines).

Biodiesel has been registered as a legal fuel for use in the United States by the EPA and ASTM standards have been approved to aid states with regulating fuel quality (ASTM D 6751-02). State Weights and Measures offices are responsible for ensuring fuel quality in the United States. ASTM provides the guidelines in most cases, although there are no standards for blends of biodiesel and diesel fuel, such as B20 or blends of SVO and diesel fuel.

The most popular biodiesel blends in the marketplace today are:

- B20 was approved by Congress in 1998 as an EPAct fuel for federal, state, and publiclyowned fleets required to meet mandated alternative vehicle use targets,

- B2 has been promoted at the state level and is the anticipated blend level if the Renewable Fuel Standard portion of the proposed Energy Bill is passed.

B100 will always be limited to small niche markets because of its retail price and because most equipment needs minor modifications to use B100. Retail B100 sales may never exceed 10 million gallons, even if incentives are offered to reduce fuel prices. Markets that could support the cost of using B100 through health or environmental savings include backup power generators, mining, marine, national and state parks, concerts, and other public relations efforts by commercial businesses. Emission trading and other cost offsets would be welcome.

\subsubsection{B20}

A blend of $20 \%$ biodiesel and $80 \%$ diesel No. 2 or No. 1 by volume is referred to as B20. B20 can be used wherever diesel fuel is used - on-road transportation, equipment used in farming, forestry, mining, construction, electricity generation, marine vessels, locomotives, and even aviation. No equipment modifications are required. B20 reduces (not eliminates) problems associated with cold weather, stability, material compatibility, NOx increases, storage tank 
cleanliness, and costs. By in large, the problems are diluted to the point where they are either manageable or reach an undetectable level.

B20 market penetration is still limited by:

- High costs - B20 costs as much as $\$ 0.20 /$ gal more than diesel fuel

- $2 \%$ NOx emission increase typically seen with B20

- Cold flow management costs

- Lack of an ASTM B20 standard

- Limited emission benefits compared to new, low emission engines or after-market adds on such as PM traps, etc.

- And, in the case of electric generation, lack of a definition that identifies biodiesel as a green fuel, biomass fuel, renewable fuel or an alternative fuel in various federal and state polices.

Some feedstocks contain high levels of saturated fatty acids - tallow, lard, and some yellow grease. Biodiesel produced from these feedstocks have a high risk of freezing in tanks and forming crystals that plug fuel filters. Blending these feedstocks into a B20 reduces but does not eliminate these risks. Using B100 made from unsaturated feedstocks is the primary way that cold weather risks are managed. Unfortunately there are trade-offs. Unsaturated biodiesel creates higher NOx emissions than saturated biodiesel and may require antioxidant additives to prevent degradation during storage.

Consumer anxiety over cold flow problems is very high for B20 blends in general, and saturated biodiesel blending stocks exacerbate the issue. Winter demonstrations with tallow-based B20 in Kansas and Montreal were successful despite anxiety levels and some filter plugging. Some fleets are considering summer use of saturated B100 in B20 blends to reduce NOx emissions, switching back to unsaturated B100 for B20 blends in the winter months. This strategy will require good inventory management and involves some filter plugging risks in the months straddling either season.

B20 produced from saturated feedstocks may be used in the Southern United States or blended with other feedstocks such as soy. Some saturated biodiesel is winterized, a process of freezing the saturated components and filtering them out leaving mostly unsaturated biodiesel behind. This reduces yield and adds costs unless another market for saturates esters is available.

The result of this technical barrier is that only a small fraction of the available saturated fat supply will be used to produce biodiesel for the B20 market. The biodiesel industry will be largely limited to vegetable oils and greases with low saturation levels. The biodiesel industry projects a B20 market size of about 350 million gallons of B100 by 2015 . Which, coincidently, is about the same size of the amount of soy and yellow greases available for biodiesel production. 
Table 8. On-road Market Penetration Scenario for B100 used for B20 Fuels

\begin{tabular}{|c|c|c|c|}
\hline \multicolumn{1}{|c|}{} & $\mathbf{2 0 0 5}$ & $\mathbf{2 0 1 0}$ & $\mathbf{2 0 1 5}$ \\
\hline Market Penetration & & & \multicolumn{1}{|c|}{} \\
\hline Freight Trucks & $0.50 \%$ & $1 \%$ & $1 \%$ \\
\hline Intercity Bus & $10 \%$ & $15 \%$ & $15 \%$ \\
\hline Transit Bus & $2 \%$ & $5 \%$ & $5 \%$ \\
\hline Light-Duty Vehicle & $5 \%$ & $10 \%$ & $10 \%$ \\
\hline School Bus & $5 \%$ & $10 \%$ & $10 \%$ \\
\hline B100 Sales for B20, mil gal/yr B100 & \\
\hline Freight Trucks & 33 & 79 & 89 \\
\hline Intercity Bus & 6 & 9 & 9 \\
\hline Transit Bus & 3 & 8 & 8 \\
\hline Light-Duty Vehicle & 22 & 74 & 101 \\
\hline School Bus & 9 & 18 & 18 \\
\hline Total On Road Demand & 73 & 188 & 225 \\
\hline
\end{tabular}

Consumers have requested an ASTM standard for B20. The current practice is to blend two ASTM products (diesel and biodiesel). In theory, this ensures that the resulting B20 is problem free. However, many customers are receiving their B20 preblended and have no way to tell the following:

- Whether the blend really contains $20 \%$ (or the requested percentage biodiesel)

- Whether the biodiesel in the blend met ASTM standards, particularly with regard to the presence of bound and free glycerin that create operational problems.

- Whether the biodiesel was made from "virgin" or other sources, particularly if tax credits are involved or purchasing specifications called for a particular feedstock.

The ASTM biodiesel working group is addressing this issue. There are several methods under development to test biodiesel content. Determining glycerol (bound and free) content is more difficult. Determining feedstock source will be challenging, particularly if the biodiesel producer is blending feedstocks from various sources to meet technical or economic targets. All three issues become more challenging at even lower blends such as B2. Proposed federal or even state regulations that target incentives for specific feedstocks can retard industry attempts to minimize costs or maximize the use of local biomass oil resources.

B20 faces an uncertain future primarily because it is marketed as an emission reduction technology. Diesel engines are becoming cleaner, to the point where diesel engine technology should meet or exceed emissions of some of the cleanest engine technology available todaynatural gas, by 2007 if not sooner. There are also retrofit kits for diesel engines (particulate traps, oxidative catalysts, NOx catalysts), and other low-emission fuels such as diesel water emulsions, ethanol-diesel mixtures, Fischer Tropsch, etc. By 2010, most consumers interested in clean diesel technology will be purchasing new engines rather than clean fuels. Clean fuels may still offer 
incremental benefits, although the cost per ton of emission reduction may increase. Thus, the market niche for B20 must either redefine itself or face a declining market share in the years following 2015.

In contrast to the emission-driven on-road B20 market, federal and military fleets have required fleets of 20 or more vehicles to reduce their consumption of petroleum by $20 \%$ by 2005 . Military use has grown from 1.5 million gallons of B20 in 2001, to 15.9 million gallons of B20 in 2003 . If $20 \%$ of all military diesel is replaced with B100 by 2015, that will represent almost 200 million gallons of B100 for military uses alone. The military is using B20 in vehicles, generators, and a variety of non-tactical equipment.

\subsubsection{Low Level Blends (B2 to B5)}

Biodiesel is sold in low blend formulations, typically $2 \%$ biodiesel added to petroleum diesel by volume. Low blends such as B2 are being sold commercially throughout most farm states at Cenex and Farmland outlets as a premium diesel fuel. Other additives are also added to the diesel fuel to ensure the premium fuel meets standards set by the National Council of Weights and Measures. B5 and lower blend levels meet the ASTM standard for diesel fuel and all Original Engine Manufacturer warrantees.

The primary purpose of B2 is as a lubricant, particularly for ULSD that will be made available nationwide by 2006. The production process for making ULSD severely reduces its natural lubricity characteristics. Engine manufacturers have relied on the natural lubricating properties of diesel fuel in their engine designs. Refiners plan to use a variety of low cost additives to solve the problem. However, there are concerns that have come to light during the early introduction of ULSD which include: over additization causing fuel filter plugging, under additization that could lead to fuel pump failures, and unanticipated reactions between two or more different additive packages that could occur in bulk storage or while traveling across country.

In March 2002, Minnesota enacted the nation's first biodiesel mandate that would require nearly all diesel fuel sold in the state contain at least $2 \%$ biodiesel by 2005 if one of the following conditions occur:

- Minnesota biodiesel production capacity exceeds 8 million gallons/yr

- 18 months have passed since a federal action on tax imposed, tax credits, or other action creates a reduction of price of 2 cents per gallon of B2

- June 30, 2005 has passed.

For a complete legal description of the regulation see: http://www.revisor.leg.state.mn.us/stats/239/77.html

Figure 11. Minnesota B2 Mandate

The side benefit of a B2 strategy is that both technical and economic problems associated with biodiesel are minimized. The benefits (other than lubricity) are also minimized but can be viewed at an aggregate level. In addition, all feedstocks could be used including saturated animal fats and greases. The cold flow performance difference between biodiesel made from various 
feedstocks narrows at a B2 level to the point where it becomes minor (Figure 12). This strategy, which uses all types of biomass oils for biodiesel production, will maximize petroleum displacement potential.

B2 can be a fungible fuel nationwide with a predictable lubricity level that exceeds minimum standards. A national B2 strategy would eliminate some of the additization problems already identified in the ULSD market and create a market for up to one billion gallons of B100 by 2015 . Since other fuel markets are being slowly converted to lower sulfur content diesel, future markets for biodiesel as a lubricant could encompass more than highway users. Using the total estimate of diesel demand by 2015 ( 80 billion gallons) as much as 4 billion gallons of B100 could be consumed by 2015 .

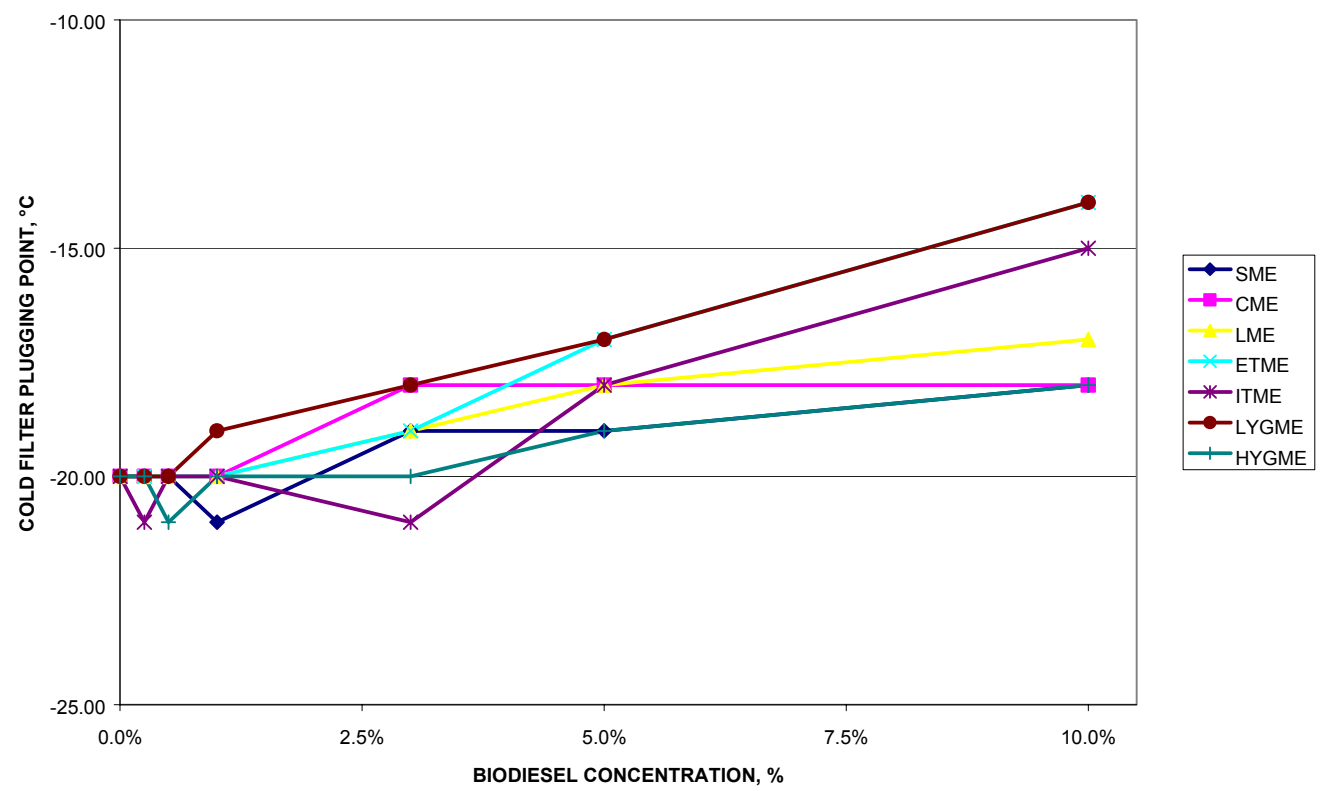

Figure 12. Cold Filter Plug Point for Low-Blend Biodiesel Fuels ${ }^{18}$

Table 9. Market Potential of $\mathrm{B} 100$ as a B2 Blend

\begin{tabular}{|l|l|l|l|}
\hline & $\mathbf{2 0 0 5}$ & $\mathbf{2 0 1 0}$ & $\mathbf{2 0 1 5}$ \\
\hline \hline Percentage blend & $1 \%$ & $1.50 \%$ & $2 \%$ \\
\hline \hline Market Penetration & $100 \%$ & $100 \%$ & $100 \%$ \\
\hline \hline On-Highway, mil gal/yr B100 & 374 & 677 & 1,030 \\
\hline
\end{tabular}

\subsubsection{Heating oil blends with biodiesel}

Biodiesel can be used in 20\% blends with No. 2 heating oil in residential boilers for home heating and industrial/commercial hot water and steam boilers. Initial tests at Brookhaven

\footnotetext{
${ }^{18} \mathrm{SME}=$ Soy methyl ester, $\mathrm{CME}=$ canola methyl ester, LME=lard methyl ester, ETME=Edible tallow methyl ester, ITME=inedible tallow methyl ester, LYGME=low free fatty acid yellow grease methyl ester, HYGME=high free fatty acid yellow grease methyl ester. Kinast, J. March 2003. Production of Biodiesels From Multiple Feedstocks and Properties of Biodiesel and Biodiesel/Diesel Blends. NREL/SR-510-31460.
} 
National Laboratories showed good reductions in air emissions across the board including NOx, which fell by 20\%. ${ }^{19}$ The Massachusetts Oil Heat Council conducted tests on a wider range of boilers at the New England Fuel Institute on the behalf of the heating oil industry, which confirmed and expanded on the Brookhaven findings. ${ }^{20}$ Limited field testing has not revealed any issues that were not already anticipated from previous B20 experience. The Warwick School District has been using B20 in four elementary buildings for the last two years. USDA uses B5 at its Beltsville, MD facility. NYSERDA has provided a grant to support at least one NY heating oil company conduct a field study of 100 residential customers for the 2003-2004 winter season. Several other heating oil firms in the Northeast are marketing B20 this winter season.

Initial discussions with heating oil personnel indicate that the majority of consumers may be extremely price sensitive while a small percentage are willing to pay extra for "green" heating oil. Segregating the willing consumers onto separate fuel routes will add costs and distributors would rather shift their entire customer list to a blended fuel. Large scale shifts can only be handled through customer rebates, incentives or other mechanisms that reduce the impact of higher fuel costs on vulnerable consumers (poor, elderly). Table 10 shows two of many possible scenarios that could occur in residential heating oil market depending on biodiesel price trends and incentive programs.

Table 10. Residential Heating Oil Displacement Scenarios

\begin{tabular}{|c|c|c|c|c|}
\hline Scenario & & 2005 & 2010 & 2015 \\
\hline \multirow{3}{*}{$\begin{array}{l}\text { High cost, No } \\
\text { subsidy Biodiesel }\end{array}$} & Percentage blend & $5 \%$ & $5 \%$ & $5 \%$ \\
\hline & Market Penetration & $1 \%$ & $10 \%$ & $40 \%$ \\
\hline & $\begin{array}{l}\text { Residential Biodiesel Use, } \\
\text { mil gal/yr B100 }\end{array}$ & 3.5 & 34.0 & 129.9 \\
\hline \multirow{3}{*}{$\begin{array}{l}\text { Low cost or } \\
\text { Subsidized } \\
\text { Biodiesel }\end{array}$} & Percentage blend & $5 \%$ & $10 \%$ & $10 \%$ \\
\hline & Market Penetration & $1 \%$ & $10 \%$ & $30 \%$ \\
\hline & $\begin{array}{l}\text { Residential biodiesel Use, } \\
\text { mil gal/yr B100 }\end{array}$ & 3.5 & 67.9 & 194.8 \\
\hline
\end{tabular}

The key question people are asking is whether the biodiesel used for heating oil has to meet transportation fuel standards or if a lower grade biodiesel could be used. It's not clear whether a lower grade would save any substantial processing costs unless transesterification was avoided altogether. That interest stems more from small producers who cannot afford to test their fuel and thus, feel that the transportation market is beyond their grasp while the heating oil market may not be if fuel standards can be loosened.

Beckett and Sun (heating boiler manufacturers) have commented that in recent tests with ASTM quality biodiesel, some of the problems with seals and other components that were noted during tests in the mid 1990s were not apparent. At this time, people are encouraged to use ASTM quality biodiesel for No. 2 heating oil blends in residential boilers. The biomass fuel used in

\footnotetext{
${ }^{19}$ Krisha, C.R. Biodiesel Blends in Space Heating Equipment, NREL/SR-510-33579.

${ }^{20}$ Batey, John R. Draft, Interim Report of Test Results: Massachusetts Oil Heat Council Biodiesel Project, Dec. 2002.
} 
industrial boilers should be determined on a case-by-case basis, since it has already been proven that straight SVO or WVO can be used in industrial boilers.

\subsubsection{Biomass Oils as Hydrogen Feedstocks}

Biomass oils have been evaluated as potential hydrogen feedstocks, although only the low cost greases are economically attractive. Initial research at NREL shows solid promise and excellent yields. ${ }^{21}$ Low quality materials may need preliminary pretreatment prior to conversion to hydrogen in fluidized bed reforming systems to avoid fouling catalysts and to maximize yields. Simple water washing and filtering was determined to be adequate.

This technology may be particularly attractive for trap greases, a highly degraded grease found in restaurant traps that has no viable market at this time. These greases can be made available for between 2 and 7 cents per pound depending on the degree of pretreatment required.

\subsubsection{Converting Biomass Oils to Hydrocarbon Fuels}

The first oil-based hydrocarbon fuel is called Agtane, marketed by Adept Group, Inc. Agtane is produced in a medium severity hydroprocess using conventional petroleum refining hardware under specific temperatures and pressures developed by Natural Resources Canada, the Saskatchewan Research Council, and Agri-Food Canada. ${ }^{22}$ Several refinery reactions occur in the process: hydrocracking to break down the triglycerides into glycerine and fatty acids; hydrotreating to remove the hydroxyl compound at the end of each fatty acids (similar to the production of fatty alcohols), and hydrogenation to saturate the double bonds (also reduces the glycerol into ethylene). Nearly all of these processes have equivalent counterparts in the oleochemical industry. Hydrotreating catalyst deactivation was the primary obstacle to overcome in this technology. The product consists of straight, long-chain paraffins for use as a blending stock or as a Cetane improver for diesel fuel. The Cetane number of Agtane is approximately 100 , and thus a blend of $10 \%$ Agtane with $90 \%$ diesel would raise the Cetane number by approximately 6 points. Adept Group refers to Agtane as a synthetic diesel fuel, similar to Fischer Tropsch diesel. As it is composed of long-chain paraffins, the product has high cloud and gels points (in excess of $20^{\circ} \mathrm{C}$ or $75^{\circ} \mathrm{F}$ ) and may not be suitable for blending year round without proper management. Blend levels such as $2 \%$ may be considered, although the Cetane advantage would be minimized. The developers set the cost of producing Agtane at \$1.28/gal including feedstock cost, but feedstock must represent the largest part of that total cost estimate. Given the scale of most petroleum refineries compared to biodiesel plants, refinery costs will probably be less than those for biodiesel and more similar to diesel fuel production costs.

Marc Portnoff, of Carnegie Mellon, has applied for several patents in a slightly different vein that uses conventional refining technology in combination with some new modifications to convert biomass oils into distillate fuels. ${ }^{23}$ Conversion costs are claimed to be equal to those for petroleum refining.

\footnotetext{
${ }^{21}$ S. Czernik (PI), R. French, K. Magrini., Performance of a Fluidisable Attrition-Resistant Catalyst in the Process of Steam Reforming of Trap Grease. NREL milestone report, September 2003.

${ }^{22}$ UNITED STATES Patent \#5,705,722 and \#4,992,605.

${ }^{23}$ Production of Biofuels, Reference No. 019504-9001-00, Filed on October 17, 2002. Catalyst for the Treatment of Organic Compounds, Reference No. 019504-9002-00, Filed on October 17, 2002. Catalytic Process for the Treatment of Organic Compounds, Reference No. 019504-9003-00, Filed on October 17, 2002
} 
Using biomass oils as refinery feedstocks presents a least-cost processing option to the industry. It avoids new capital investment, takes advantage of large economies of scale and low processing costs, and offers the opportunity to displace more expensive feed streams or provide lower cost blend stocks for gasoline, diesel, and other refinery product slates. Assuming that refinery processing adds approximately 15 cents/gal to crude oil, this is considerably less than the cost of biodiesel production. In addition, biomass oils that are transformed into existing refinery products can be transported, stored, distributed and used in existing industry infrastructures.

What is needed at this point is a demonstration of these technologies on a scale sufficient to collect data on fuel quality and composition, fuel performance and emissions, and impact on refinery and infrastructure technology. It is not clear that the approach used for Agtane, or the lesser known Carnegie Mellon approach, is sufficient as is. Further optimization of refinery units may be necessary before large-scale demonstrations can be pursued. However, given the least cost processing potential, and the potential for seamless integration into the existing fuels infrastructure, this idea is worth pursuing further if an industrial partner can be identified.

In the absence of incentives or mandates, the market potential of this technology is limited by feedstock economics. Feedstock pretreatment may be required for some feedstocks to reduce contaminates that may foul catalysts, but those requirements will be reflected in the various grades and costs of feedstocks available. If refiners limit their feedstock selection to the least expensive feedstocks for a particular quality standard, this technology may not lead to maximizing oil displacement unless incentives are large enough to overcome the high cost of vegetable oil feedstocks.

\subsubsection{Something New?}

A new fuel or fuel additive, different from all of the above, could be developed, such as branched alcohols on fatty acids, glycerol tertiary-butyl ether, etc. Since biomass oil production costs are concentrated in the feedstock, significant savings may not be realized by developing a new conversion process, although technical barriers such as cold flow and stability could be targeted.

The economic barriers facing new fuel development includes the total cost of such a project and the lack of political stakeholder support. The cost to develop biodiesel, including all DOE, USDA, and funding from soybean check off dollars, exceeded $\$ 30$ million over a period of 8 years before commercial fuel sales began to register. A new fuel would cost more to develop because of the need to develop the new fuel chemistry and optimize new production process, which had been commercial for biodiesel since the 1930s. EPA registration testing, fleet demonstrations, material compatibility testing, fuel blend optimization, and development of ASTM standards, would all need to be repeated for the new fuel formulation. Biomass oil stakeholders have already made one investment (in biodiesel) and are very reluctant to make a new investment at this time. So the potential $\$ 30+$ million dollar investment for a new fuel may need to be borne solely by the government if this route is selected, since stakeholder support (which funded the lion's share of the initial biodiesel investment) will be largely absent. 
The one exception to the statement above would occur if the new fuel is composed solely of nonoxygenated hydrocarbons and meets all the criteria set forth in ASTM D 975 for diesel fuel. Agtane and the "bio-distillates" developed by Carnegie Mellon meet this definition. In these situations, the new fuel could be considered indistinguishable from petroleum distillates and thus, exempt from EPA registration or included under the preexisting petroleum fuel registrations. Fuel producers would still need to register but only basic fuel property testing would be required. Some of the other testing identified above (material compatibility, cold flow, Cetane, corrosion, etc.) may be needed to establish market acceptance.

Any new fuel will be competing with biodiesel for market share and feedstocks. In the case of "bio-distillates" that gain the acceptance of refiners, the new product could succeed. Otherwise, the longer established product - biodiesel - may win, more because of prior market acceptance than from any intrinsic benefits posed by biodiesel.

\subsection{Petroleum Displacement Strategies}

Biomass oil fuels' most attractive features are the low technical hurdles associated with using them. Typically, little or no engine or infrastructure modification is required, particularly with B20 and lower level blends. The primary market barriers are feedstock cost, supply limits, and technical barriers created by any significant departure from typical distillate characteristics or performance parameters.

To maximize the use of biomass oil fuels and the displacement of petroleum, one must select those fuels or blends that minimize both cost and technical issues. Since incentives will benefit any use of biomass oils, we will ignore them for this discussion.

Unesterified biomass oils are the least expensive of the fuels by virtue of minimal processing. Given their potential uses as either boiler fuels (45 million gallons per year by 2010) or blend agents in diesel fuel (should be avoided in CI engines), these fuels do not offer substantial oil displacement.

Biodiesel used as a neat fuel (B100) is too expensive for significant market penetration and presents technical barriers that limit its use in the near term.

Both cost and technical barriers are minimized with low blend strategies using biodiesel or biodistillates, and thus, either of these two fuels may offer substantial oil displacement benefits.

Both fuels may have a role in future distillate markets. The pros and cons are listed below: 
Bio-distillates:

- The bio-distillates route is commercially unproven on a large scale as either straight throughput or as a blend with crude oil or other internal slipstreams.

- The upper limits on the biomass oils concentration in petroleum refining operations has not been determined and creates strategic uncertainties - can you go from $1 \%$ to $5 \%$ to $10 \%$ ?

- Processing costs may be minimized based on economies of scale present in refineries, and will probably be lower than processing costs at the smaller biodiesel plants.

- So long as the bio-distillates are marketed as components in a diesel fuel product, distribution costs will be minimized.

- Bio-distillates sold as mainstream diesel fuel will not have any price advantage to offset higher feedstock costs.

- Bio-distillates sold as premium fuels may cover the higher feedstock costs.

- Supplying large volumes of oil to a relative few facilities could limit the number of locations that this approach succeeds in.

Biodiesel:

- B100 production costs, even on a large scale, add at least 30 cents to a gallon of biomass oil feedstock cost.

- Facilities can be small and located where feedstock is available.

- Distribution costs for B100 will continue to reflect niche market costs similar to ethanol (add 40 cents per gallon) and also have the added disadvantage of requiring heated transportation and storage and in some cases antioxidants for B100 storage stability.

- All feedstocks can be used as a B2 or B5 blend stock, which minimizes both economic and technical barriers associated with biodiesel.

- $\quad$ B2 and B20 are marketed as a premium fuel, which justifies their higher price.

- As biodiesel blends move to mainstream diesel markets (e.g., on highway and other commercial applications - railroad, barges, shipping, electricity generation, etc.) strong lobby groups (API, American Trucking Association, American Railroad Association) will oppose their use.

- Biodiesel production creates glycerin. As biodiesel production increases growing supplies of glycerin will drive down its price and byproduct revenue for biodiesel producers, raising biodiesel costs.

It is this author's opinion that both biodiesel and bio-distillates have the potential to succeed in the market place, albeit at different locations. Allowing the two technologies to compete for feedstocks and marketing those products that best suit regional and local needs may offer the largest petroleum displacement strategy of all. The potential for oil displacement is addressed in following section: Biomass Oil Supply and Production. 


\section{BIOMASS OIL SUPPLY AND PRODUCTION}

The primary goal of EERE research is to reduce or eliminate petroleum imports. How much petroleum can biomass oils displace? As Figure 13 shows, imports comprise the majority of United States petroleum supplies today and well into the future under a status quo scenario with no supply or price shocks. To displace a fraction of imports, the new industry must grow faster than demand in order to garner an increasing share of the import market. The only industries that grow in such as fashion are those with a clear economic advantage or significant subsidies. As with other biofuels, biomass oils will need incentives in order to successfully displace imported petroleum until the impacts of real shortages manifest themselves.

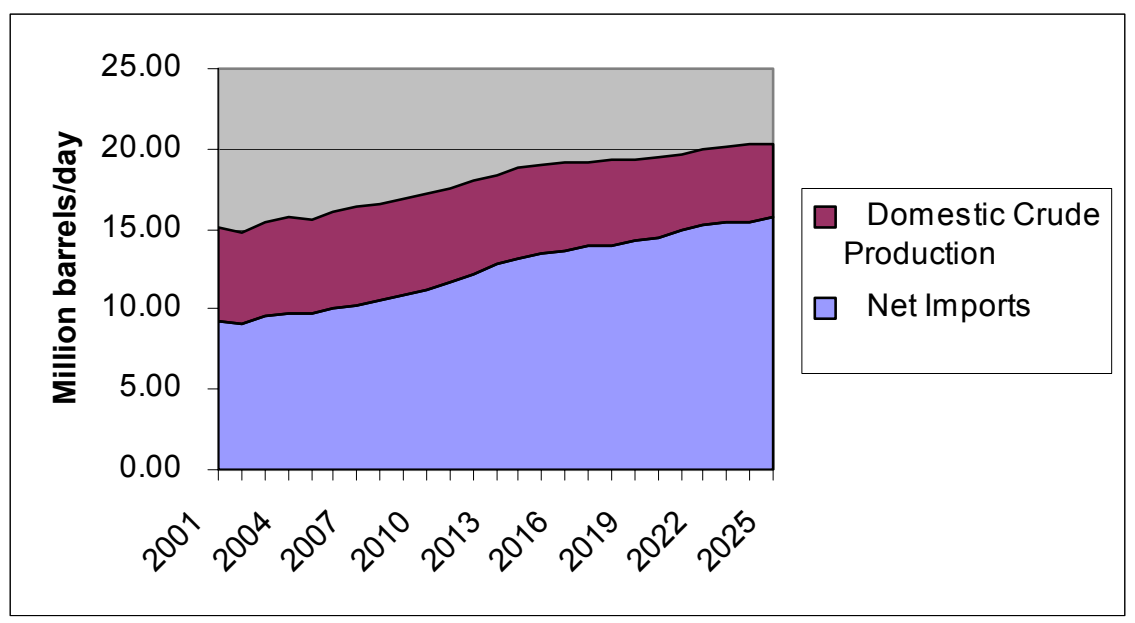

Figure 13. United States Petroleum Supply Forecast, AEO 2003 Early Release, Table 11.

\subsection{Current Biomass Oil Supply}

At this time, the production of biomass oils in the United States is closely tied to current demand. Thus, when we examine how much petroleum can be displaced with the current supply of biomass oils, the answer appears to be very limited. However, the appropriate public policy and research investments can increase future biomass oil supplies, particularly if energy demand for biomass oils expands.

The United States produced 43.8 billion pounds of biomass oils in 2001 and imported another 4.2 billion pounds of vegetable oils (Table 11). ${ }^{24}$ Thus, total United States biomass oil production is equivalent to 0.37 million barrels per day, or about $3.7 \%$ of current petroleum imports. That is also equivalent to $10 \%$ of our total distillate demand in 2001 , or $17 \%$ of the highway consumption of diesel fuel.

\footnotetext{
${ }^{24}$ The petroleum industry works in millions of barrels (42 gallons/barrel) per day (bbls/day) and the biomass oil industry uses billion of pounds (7.7 pounds/gal) per year. Approximately 7.4 pounds of biomass oil plus 0.74 pounds of methanol are used to make 1 gallon of biodiesel $(7.4 \mathrm{lb} / \mathrm{gal})$ and $0.74 \mathrm{lbs}$ of glycerol.
} 
Table 11. United States Production, Imports, Exports, and Apparent Consumption of Fats and Oils for 2001.

\begin{tabular}{|c|c|c|c|c|c|}
\hline Oil and Fats & Production & Stocks & Imports & Consumption & Exports \\
\hline & MMlbs & MMlbs & MMlbs & MMlbs & MMlbs \\
\hline Soy $^{1}$ & 18,898 & 2,877 & 46 & 16,958 & 2,250 \\
\hline Corn $^{1}$ & 2,459 & 117 & & 1,342 & 1,130 \\
\hline Cotton $^{1}$ & 870 & 90 & & 767 & 140 \\
\hline Canola $^{1}$ & 713 & 110 & 1,108 & 1,493 & 276 \\
\hline Sunflower $^{1}$ & 713 & 136 & 16 & 375 & 465 \\
\hline Peanut $^{1}$ & 230 & 25 & 39 & 250 & 18 \\
\hline Safflower $^{1}$ & 76 & 21 & 40 & 89 & 37 \\
\hline Coconut $^{1}$ & & 260 & 1,150 & 1,100 & 11 \\
\hline Cocoa butter & & & $178^{3}$ & & \\
\hline Olive $^{1}$ & & & 455 & 455 & \\
\hline Palm $^{1}$ & & 61 & 490 & 471 & 2 \\
\hline Palm Kernal $^{1}$ & & 155 & 330 & 355 & 10 \\
\hline Linseed $^{1}$ & 195 & 43 & $10^{3}$ & 103 & \\
\hline Tall oil ${ }^{2}$ & 1,157 & & & 1,294 & \\
\hline Castor & $75^{3}$ & & $100^{3}$ & $39^{2}$ & \\
\hline Minor Oils ${ }^{3}$ & 196 & & & 196 & \\
\hline Rapeseed & & & $1190^{3}$ & $\mathrm{~N} / \mathrm{a}$ & \\
\hline Tung & & & $25^{3}$ & $7^{2}$ & \\
\hline Edible Tallow ${ }^{1}$ & 1,920 & 49 & & 1,474 & 465 \\
\hline Lard $^{1}$ & 1,080 & 14 & & 989 & 85 \\
\hline Inedible Tallow $^{2}$ & 3,449 & 316 & 66 & 3,062 & 1,348 \\
\hline Inedible greases $^{2}$ & 2,450 & & & & \\
\hline Other fats and oils ${ }^{2}$ & 32 & & & 60.5 & $399^{7}$ \\
\hline Vegetable oil foots ${ }^{2}$ & 365 & & & 98.0 & \\
\hline Poultry fat ${ }^{4}$ & 2,215 & & & $\mathrm{~N} / \mathrm{a}$ & \\
\hline Fish Oils $^{6}$ & 279 & & 249 & $\mathrm{~N} / \mathrm{a}$ & \\
\hline Yellow grease $^{4}$ & 2,633 & & & $\mathrm{~N} / \mathrm{a}$ & $406^{7}$ \\
\hline Trap grease $^{5}$ & $3,808^{5}$ & & & & \\
\hline 3.1.1.1.1.1 Total & 43,813 & 4,274 & 5,492 & 30,978 & 7,042 \\
\hline \multicolumn{6}{|c|}{$\begin{array}{l}{ }^{1} \text { USDA ERS Oil Crops Situation and Outlook, October } 2002 .{ }^{2} \text { Bureau of Census, M311K-Fats and Oils: } \\
\text { Production, Consumption and Stocks, 2002, July 2003. }{ }^{3} \text { USDA ARS, Agricultural Statistics, 2003, Chapter III. }{ }^{4} \\
\text { Pearl, Gary. Biodiesel Production in the United States, Australian Renderers Association } 6{ }^{\text {th }} \text { International } \\
\text { Symposium, July } 25-27,2001 .{ }^{5} \text {.Estimated from Wiltsee, G., "Urban Waste Grease Resource Assessment," NREL- } \\
\text { SR-570-26141. }{ }^{6} \text { USDA ARS, Agricultural Statistics, Chapter XV. }{ }^{7} \text { Render, April 2002, pg. } 12 . \\
\text { Note: Numbers do not add, because of withheld data, data gaps, and other missing data, totals for stocks, imports } \\
\text { and exports may be misleading due to high number of missing data points. }\end{array}$} \\
\hline
\end{tabular}


Most of the biomass oils produced in this country are also consumed here. Fats and oils are consumed in food, animal feed, and oleochemical production. A small amount (approximately 20 to 40 million gallons) is also currently used for fuel (converted to biodiesel or used directly as a boiler fuel), but no reliable statistics exist.

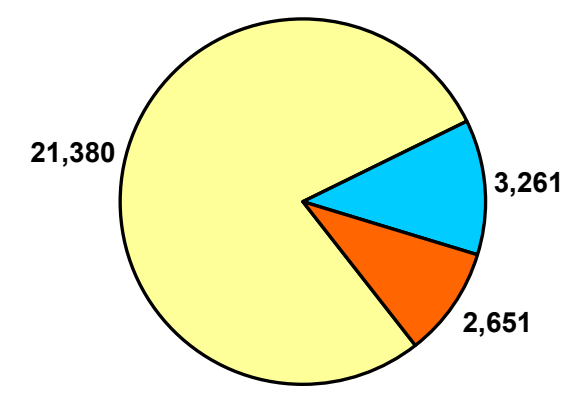

$\square$ Food $\square$ Industrial Products $\square$ Feed
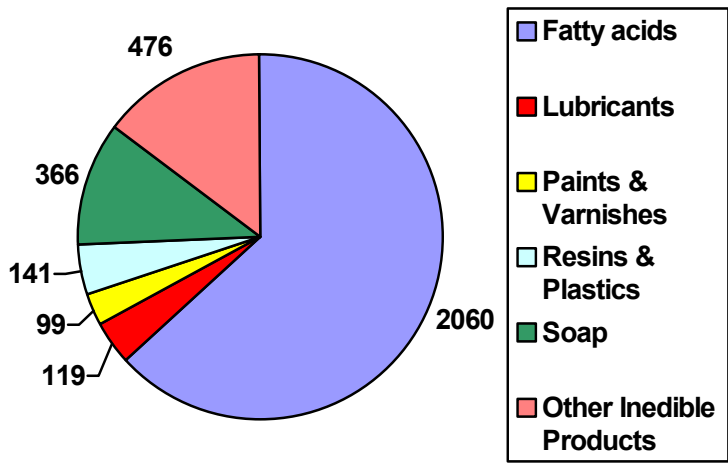

Figure 14. Fat and Oil Consumption and Use in Industrial Products, Millions of pounds 2001. ${ }^{25}$

Current surplus estimates are typically the sum of inventories plus exports. ${ }^{26}$ The key assumption is that as domestic energy markets for biomass oils grow, exports would be redirected to domestic use in the short term, particularly since increasing foreign oil competition (soy, palm) is dampening export demand. Inventories are not generally available for new demand because they are necessary for business operations. Most inventory levels are about $10 \%$ of production.

If we limit available supplies to exported oils, the United States could have supplied 1.6 billion gallons of biomass oils to displace petroleum fuels in 2001 (Table 12). That amount could have produced almost 1.7 billion gallons of biodiesel and displaced 3\% of total distillate demand, or $5.5 \%$ of on highway diesel demand using low level blends, or $1.1 \%$ of petroleum imports today.

Production, demand, exports, inventories and prices can vary greatly from year to year as a result of acreage planted, oilseed crush, demand for meal, weather, foreign competition, competition from other fats and oils, and even exchange rates. As a result, the amount of biomass oils available for energy is not a fixed estimate. Nor should anyone ever assume that every pound of oil exported could be diverted to energy use. So the current supply potential for a domestic energy industry will probably be less than the estimates shown below.

Biomass oil supply is vulnerable to disease, pests, drought, floods, and climate change. Biofuels may make incremental contributions to domestic energy supply but do not eliminate the risk of supply interruptions.

\footnotetext{
${ }^{25}$ USDA

${ }^{26}$ Where export estimates are not provided, a proxy for exports is used to calculate "surplus supplies" which is equal to production-consumption. Inventories are assumed to remain relatively constant from one year to the next.
} 
Table 12. Current Biomass Oil Supplies Available for Energy Use in 2001

\begin{tabular}{|c|c|c|c|}
\hline & $\begin{array}{l}\text { Million } \\
\text { Lbs/yr }\end{array}$ & $\begin{array}{l}\text { Million } \\
\text { Gal Oil } \\
\text { Per yrl }\end{array}$ & $\begin{array}{l}\text { Million } \\
\text { Gal B100 } \\
\text { Per yer }\end{array}$ \\
\hline Soy & 2,250 & 292 & 304 \\
\hline Corn & 1,130 & 147 & 153 \\
\hline Sunflower & 465 & 60 & 63 \\
\hline Canola $^{1}$ & 0 & 0 & 0 \\
\hline Cottonseed & 140 & 18 & 19 \\
\hline Peanut & 18 & 2 & 2 \\
\hline Safflower & 37 & 5 & 5 \\
\hline Linseed & 135 & 18 & 18 \\
\hline Edible tallow & 465 & 60 & 63 \\
\hline Lard & 85 & 11 & 11 \\
\hline Inedible tallow \& greases & 2,837 & 368 & 383 \\
\hline Other fats \& oils & 399 & 52 & 54 \\
\hline Poultry fat & 221.5 & 29 & 30 \\
\hline Fish oils & 27.9 & 4 & 4 \\
\hline Yellow grease & 406 & 53 & 55 \\
\hline Trap grease & 3,808 & 495 & 514 \\
\hline Total biomass oils & 13,424 & 1,614 & 1,677 \\
\hline
\end{tabular}

This total supply of biomass oil feedstocks available for energy is not necessarily available for all types of energy uses. Highly saturated feedstocks such as tallow and lard will play a limited role in B20 markets because of their cold flow properties; however they are not limited in B2 or B5 markets. Prices limit the use of other oils, unless incentives offset some of that premium. Soy biodiesel expansion has been supported by USDA BioEnergy incentives,${ }^{27}$ without which, B20 markets would be significantly smaller and grow much more slowly given their high cost feedstock.

The current supply of biomass oils available for energy use is enough to replace all highway No. 2 diesel fuel with B5 blends while still meeting the needs of United States demand for oils for food, feed and oleochemicals.

\footnotetext{
${ }^{27}$ These production incentives are discussed in the following chapter on production technology and costs. Also see http://www.fsa.usda.gov/daco/bio_daco.htm.
} 


\subsection{Near Term Expansion Potential (2015)}

Animal fats and grease supplies are limited and do not tend to expand with demand for biomass oils because they are byproducts of other industries - meat production, meals eaten outside the home, etc. This situation is also partially true for soy oil. Only 19\% of a soybean consists of oil while the remainder is sold as high protein animal feed. Any soy crusher will tell you that the demand for meal drives their production decisions and the oil is simply a byproduct. When asked if the demand for oil for energy use (biodiesel for example) can alter their decision pattern, the typical response is "unlikely." In order for domestic soy oil supplies to increase significantly, there has to be a major increase in demand for soy meal.

Table 13. United States Production of Seed Oils and Equivalent Biodiesel per Acre, 2001

\begin{tabular}{|l|c|c|c|c|}
\hline \begin{tabular}{|l|c|c|}
\hline Oil Seed \\
Crops
\end{tabular} & $\begin{array}{c}\text { Harvested } \\
\mathbf{2 0 0 1} \\
\mathbf{1 , 0 0 0} \mathbf{A}\end{array}$ & $\begin{array}{c}\text { Seed Yield } \\
\mathbf{2 0 0 1} \\
\mathbf{l b s} / \mathbf{A}\end{array}$ & $\begin{array}{c}\text { Oil Content } \\
\text { Wt \% }\end{array}$ & $\begin{array}{c}\text { Gallons } \\
\text { Biodiesel } \\
\text { Per A }\end{array}$ \\
\hline Soybean & $73,000.0$ & 2,376 & 18 & 56 \\
\hline Cottonseed & 13,053 & 932 & 19 & 23 \\
\hline \hline Canola & 1,455 & 1,374 & 40 & 71 \\
\hline \hline Sunflower & $2,580.0$ & 1,349 & 40 & 70 \\
\hline \hline Peanuts & 1400.5 & 3,027 & 25 & 98 \\
\hline \hline Rapeseed & 3.1 & 1,306 & 40 & 68 \\
\hline \hline Safflower & 177.0 & 1,365 & 25 & 44 \\
\hline \hline Mustard (spice) & 44.2 & 930 & 40 & 48 \\
\hline \hline DOE Mustard hybrids & ------- & 2,761 & 40 & 143 \\
\hline \hline Castor & & 2,200 & $20-40 \%$ & $\sim 600$ \\
\hline
\end{tabular}

\subsubsection{Basic Crushing Costs and Implications}

Table 14 shows what a typical crusher's gross margin looks like for canola and soybean crushing. The gross margin - total revenues less feedstock cost - is used as an estimate of crushing costs including returns to investment by most of the industry because the industry is mature and cost structures are well known. ${ }^{28}$ It is also a key price signal to crushers that tells crusher to either expand or contract production. The typical margin for a $n$-hexane extraction mill with a capacity of 1,500 to 2,000 tons per day is around 60 cents per bushel (1 cent per pound). Nearly $98 \%$ of United States soy crushers use $n$-hexane extraction technology. This technology is capable of extracting $99.5 \%$ of the available oil from soybeans.

When margins rise above this threshold, production of oil and meal increases. When margins fall below this threshold, production is curtailed. The threshold will vary for different crushers depending on their cost structure. Small crushers will have higher margins, sometimes as high as 3 or 4 cents per pound.

\footnotetext{
${ }^{28}$ Crusher's gross margin is also referred to as the price spread between the sum of product values and soybean prices. It is generally quoted on a per bushel basis (60 lbs per bushel).
} 
There are several misconceptions about high oil content seeds. Many people assume that these seeds can produce cheaper oil, either because more oil per acre is produced (they are assuming that oil cost $=$ seed production costs/oil per acre) or because the average crushing costs is divided among more pounds of oil produced. Neither of these assumptions is accurate, as they overlook essential elements in the cost equation.

\section{Table 14. Comparing Recent Crush Margins}

\begin{tabular}{|c|c|c|}
\hline & Canola $^{1}$ & Soy $^{2}$ \\
\hline \$/cwt (100 lbs) & 13.98 & 9.83 \\
\hline$\%$ Oil content & $40 \%$ & $18 \%$ \\
\hline Oil quantity, Ibs & 40 & 18 \\
\hline Meal quantity, Ibs & 60 & 82 \\
\hline Price Oil, \$/lb & 0.259 & 0.212 \\
\hline Price meal, $\$ / \mathrm{lb}$ & 0.077 & 0.086 \\
\hline Revenue Oil, \$ & 10.37 & 3.816 \\
\hline Revenue Meal, \$ & 4.6 & 7.04 \\
\hline Total revenue, \$ & 14.97 & 10.86 \\
\hline Less Feedstock Cost, $\$$ & -13.98 & -9.83 \\
\hline Crusher's gross returns (margin), $\$$ & 0.99 & 1.03 \\
\hline \multicolumn{3}{|c|}{$\begin{array}{l}\text { Notes: Data generally represent large-scale }(1,500 \text { to } 2,000 \text { ton per day) } n \text { - } \\
\text { hexane extraction mills. }{ }^{1} \text { February } 2003 \text { Average Prices from http://www.canola- } \\
\text { council.org/markets/canolaprices.html, adjusted to United States } \$ .1 .3369 \\
\text { CD/US. }{ }^{2} \text { February } 2003 \text { Averages prices from USDA/ERS Oil Crops Yearbook, } \\
\text { 2003, Table 10--Soybeans: Monthly value of products per bushel of soybeans } \\
\text { processed, and spot price spread, United States, } 1990 / 91 \text { to date }\end{array}$} \\
\hline
\end{tabular}

Seed prices are influenced from two directions - the farmer's production cost and the embedded value of the products that can be made from the seed. International and domestic markets for oil and meal set the prices for the outputs. Seed and crushing costs are components in these prices, but are not the sole determinate. The amount and value of the meal plays a critical role in how seed oil prices are determined. Canola meal contains 35\% protein to soy's $44 \%$ (hull included) or $48 \%$ (no hulls). Thus, canola meal sells for a discount compared to soybean meal. Typically, the oil price carries most of the crushing cost since meal prices stay close to the oilseed prices. The price of oilseeds, meal, and oil are intrinsically bound together.

Thus, producing or crushing high-oil content seeds is not necessarily cheaper than producing or crushing low oil content seeds, all other things being equal. The virtues of high oil content seeds are more efficient land use and a lower impact on the market prices of seed meal to produce the same volume of oil.

For example, if soybean acreage increased by 10 million acres at the yield average shown in Table 13, potential biomass oil supply would increase by 560 million gallons and meal supplies 
will increase by 9.74 million tons. A similar acreage increase in either sunflowers or canola would produce $25 \%$ more gallons of oil but less than half (only 4.12 million tons) as much meal as soy crushers would produce.

$n$-Hexane extraction costs are very efficient on a per pound basis ( 1 cent per pound); however it still adds 20 to 44 cents to a gallon of vegetable oil produced. ${ }^{29}$ The largest portion of oil production costs is the cost of the seed, or at least that portion of the seed that contains oil, which ranged from 76 cents per gallon for soy to 107 cents per gallon for canola in the example above.

Small, mechanical (screw press, extruder) mills may double crushing costs per gallon of oil produced because of smaller scales and lower oil yields (more oil remains in the meal, about $20 \%$ of the total oil content or $8 \%$ of resulting meal mass). Some of the higher production costs are offset by the higher value for the oil enriched meal. Even so, more efficient and lower cost technology for small-scale oil extraction is needed. Technology that reduces extraction costs for large-scale facilities would also provide benefits.

\subsubsection{Crushing Capacity Expansion}

If biodiesel demand drives up the price of vegetable oils, then we could expect some increase in soy acreage and crushing ONLY if there is a market for the meal. Siting integrated soy crushers with livestock producers will be a popular strategy for soy farmers interested in biodiesel, as we have seen with the two most recent soy crushing plants in MN.

Integrated biodiesel/crushing/livestock producers will need to weigh the value of local meal supplies with imported supply, to determine if they are putting themselves at a disadvantage with other livestock producers vis-à-vis production costs. In addition, any excess meal will also have to compete with other meal on the international market. Frequently transportation cost savings can make some projects viable in specific locations.

There is a growing interest in vegetarian-produced livestock (e.g. no animal byproduct meals or fats used in feed formulations) to reduce the risk of exposure to Mad Cow Disease (Bovine Spongiform Encephalopathy). Such a trend would increase demand for oilseed meals, particularly those with high oil content from mechanical crushing (to replace the animal fat portion of feed formulations). This would encourage new investment in small mechanical facilities (500 ton per day) and could lead to expanded oil supplies for biodiesel production. The growth of soy-protein products for human consumption has also been a rapidly expanding market that may create some new demand for soy crushing.

Between 5 and 6 billion pounds of animal protein meals are produced in the United States annually, most of which are consumed in domestic feed rations. If $10 \%$ of the animal protein meal is replaced by soybean meal (lb per lb, ignoring other feed value adjustments), 14 to 17 million gallons of new soy oil would be produced. However, if $10 \%$ of the animal protein meal is replaced by other oilseed meal (sunflower or canola) then 43 to 52 million gallons of new oil would be produced. The difference lies with the ratio of oil to meal in the oilseeds. If meal demand is the driver, a large part of the new meal production will come from soy crops.

\footnotetext{
${ }^{29}$ That estimate assumes that the entire crushing cost is associated with producing oil. Crushing benefits meal quality so some of the crushing costs should be allocated to the meal.
} 
Most new soybean crushing capacity is being constructed overseas where expanding production attracts new crushing investments. World soy oil production has increased $25 \%$ in the last five years; from 25 million tonnes to over 30 million tonnes, with most of that increase in Brazil and China. ${ }^{30}$ Production costs for Brazilian soybeans are 25\% less than United States costs, and significant land and transportation improvements will continue to focus future growth in these sectors of the world. ${ }^{31}$

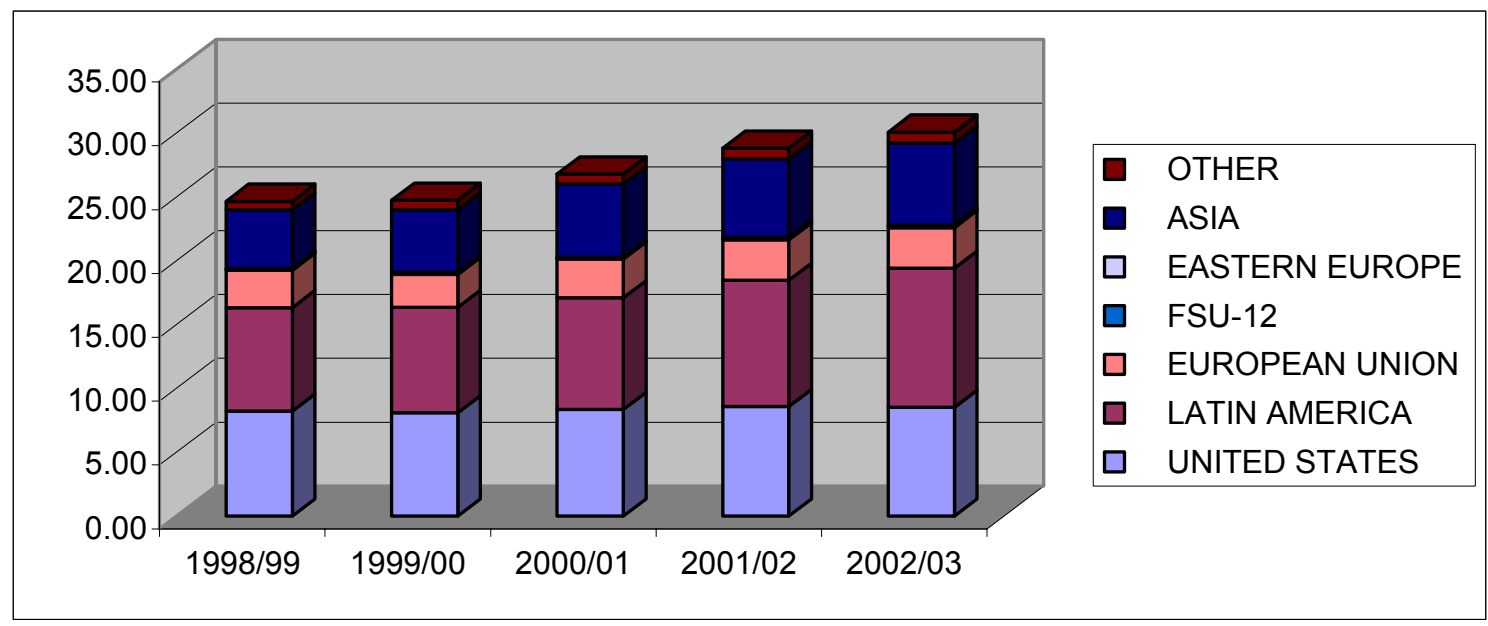

Figure 15. World Soy Oil Production, Millions Metric Tonnes per Crop Year.

These new facilities offer the highest return on investment as a result of large economies of scale (4,000 tons per day to the United States average of 2,000 ton per day), the newest technologies, low labor costs, and less stringent environmental controls. Asia, S. America and other new soy producers are expanding their domestic livestock industries to increase the amount of protein available in local diets - creating large markets for meal and increasing competition with United States oil and meal exports.

While large crushing firms such as Cargill, ADM and Bungee have taken an interest in United States biodiesel from afar, the lack of incentives or market drivers that would guarantee a return on investment prevent active participation in the United States biodiesel markets. Even if incentives become available, it is not clear that these large firms will build new crushing capacity in the United States. New capacity interest is coming from farmer cooperatives and entrepreneurs, most of which are betting on future incentives for biodiesel.

So far, it does not seem that large increases in future crushing capacity will be purely soy derived, since livestock production will only expand with meat demand. Expanding oil demand will have a more direct impact on canola, sunflower, and hybrid mustard production and crushing. These crushers expand capacity utilization when oil prices rise. If new capacity is constructed, which would be required under any significant expansion scenario, then these new

\footnotetext{
${ }^{30}$ USDA FAS Oilseed Circular, Soybean and Soybean Products, February 2003

${ }^{31}$ Schnepf, et al., December 2001. Agriculture in Brazil and Argentina: Developments and Prospects for Major Field Crops. USDA/ERS WRS-01-3.
} 
plants will also need to develop local livestock markets, or sell their meal at a discount to displace other protein feeds.

Any investment in crushing technology will require a forecast of stable or expanding feed demand coupled with stable or expanding oil prices or demand for oil products. As these investments are capital intensive, long term contracts, B2 mandates, and other incentives must be available.

\subsubsection{Land Availability for Expansion}

Corn prices have been rising in the Midwest and this has started a debate on how that will affect land use patterns. Even though soy acreage has been steadily rising the last 10 years, there is some concern that soy acreage will be replaced by corn acreage in the next 10 years. If these predictions are accurate, it could limit or reverse the amount of soy oil available in the future.

Soybean production has increased from 60 million to 73 million acres from 1993 to 2002. Corn acreage is only a few million acres more ( 79 million). Most of this new soy production has displaced wheat acreage in the northern states. Some of the increase in soy acres is driven by the increase in corn acreage because of rotation benefits, and changes in farm programs that allowed farmers to plant more acreage of oilseeds.

Soy and corn are often grown in rotation patterns to take advantage of soy's ability to sequester nitrogen in the soil. This pattern reduces natural gas-derived nitrogen fertilizer requirements for the subsequent corn crop, reducing farmer's costs and reducing fossil fuel use. So some growth in corn can be expected to create some growth in soy acres.

The growth trend in soybean acres may be tempered by increasing international competition for soybeans and soy products. If international competition for soy dampens the long-run price of soy products, we could expect to see soy land converted to corn despite rotation benefits. Some of the scenarios under debate on the future of corn ignore the impact of higher corn prices on export markets, or assume that Chinese import markets will hold up the price of corn. If there is a growing demand for oil seeds, we might see soy land converted into other oilseeds with higher oil content. There really is no way to tell exactly how land use patterns will play out given the large uncertainties in the international market place.

Recent models of the impact of biodiesel and ethanol demand on the soy sector showed a $2 \%$ increase in soy acreage as soy oil used for biodiesel increased by $10 \%$ or 433 million gallons. ${ }^{32}$ Corn land also increased by 1.4\%. Soybean yields per acre increased from 38 to 43.7 by 2013 (which is in line with USDA projections). ${ }^{33}$ The proportion of soybeans crushed compared to produced $(59 \%)$ is not forecasted to increase, but the total amount of soybeans crushed did increase $7 \%$, which implies a modest increase in soybean crushing capacity. Soy oil prices rose $35 \%$, which is unlikely given international pressure on soy oil prices from foreign producers and crushers. Rising commodity prices are an artifact of most agricultural models and are generally

\footnotetext{
${ }^{32}$ Urbanchuk, John M. November 2001. An Economic Analysis of Legislation for a Renewable Fuels Requirements for Highway Motor Fuels.

${ }_{33}$ USDA ERS 2004 Agricultural Baseline Projections to 2013, Table 10 (TAB15.wk1) http://www.ers.usda.gov/data/sdp/view.asp?f=baseline.
} 
inaccurate predictors of the future. Given the specter of foreign competition on the horizon, major expansions beyond this modest increase in the United States soybean sector are unlikely. In fact, it's more likely that U.S. crushers will be increasingly dependent on domestic markets for their oils, especially the growing energy markets. These models did not consider other R\&D improvements such as higher oil content soybean varieties that may bolster soy oil supplies in the future.

Since demand for canola and sunflower are sensitive to higher oil prices, these crops could displace wheat and other small grains. Canola-like varieties of mustard, such as the Canadian Arid or Amulet, could also play a larger role in wheat producing regions if their meal is suitable for animal feed formulations. Most of the land available for these crops is located West of the Mississippi, where CRP and other small grains can be displaced by high value oil seed production. Expansion of these crops will depend on access to crushing capacity or investments in new crushing capacity. As new crushers are established, new opportunities for local livestock production will emerge.

Wheat is the largest of the small grain crops. Wheat acreage fell from 72 million acres in 1993 to 60 million acres in 2002, primarily due to reduced export demand, drought and expanded soy production. Even so, wheat exports still exceed $57 \%$ of annual production. If wheat acreage is converted to oilseed acreage at the same rate as it declines, then approximately 700 million gallons of new biodiesel capacity could be established each decade assuming either canola or sunflower production. USDA will need to support additional research on oilseed production in the Western United States to facilitate this transfer, since good oilseed yields will be necessary to replace wheat revenues.

Table 15. Wheat and Canola Revenue Potential

\begin{tabular}{|l||l|l||l|}
\hline & Yield & Price & $\begin{array}{l}\text { Revenue } \\
\text { Per acre }\end{array}$ \\
\hline \hline Wheat & $38.5 \mathrm{bu} / \mathrm{A}$ & $\$ 3.45 / \mathrm{bu}$ & $\$ 132.83$ \\
\hline Canola & $800 \mathrm{lb} / \mathrm{A}$ & $\$ 0.12 / \mathrm{b}$ & $\$ 96.00$ \\
\hline \hline Canola & $1200 \mathrm{lb} / \mathrm{A}$ & $\$ 0.12 / \mathrm{lb}$ & $\$ 144.00$ \\
\hline
\end{tabular}

Most wheat is fall-planted winter wheat (41 million acres). Spring wheat (spring planted) represents only 15 million acres. Rapeseed is a winter crop, while mustard, canola and sunflowers are spring crops. Rapeseed meal is generally not used for animal feed except in very small amounts, which causes the production cost for inedible rapeseed oil to generally exceed 90 cents per pound. Canola is a hybrid rapeseed where the oil was designed to be edible and the meal designed for animal feed. If the oilseeds only displace spring wheat, then very little land will be converted. If winter wheat is displaced with oilseeds, then a larger production potential is offered. A lot depends on how the oilseed crops fit into the farmer's crop rotation strategy, which includes pest control, soil moisture retention, income potential, risk, equipment, knowledge, and other farm benefits that might occur. One benefit already noted for rape and mustard crops is an allopathic effect on wheat pests that causes wheat yields to increase. For these and other reasons, good USDA support for these minor oil seeds will be important for wheat farmers. 
Other small grains (barley, oats, rye, sorghum) are small acreage crops already (5 to 10 million acres) and do not represent significant land resources for oil seed production.

A large part of arable land in is in hay, which has grown from 59 million acres to 64 million acres from 1993 to 2002 . Alfalfa represents 23 million of those acres. Oilseeds will not displace alfalfa. Grass hay will not be displaced where it is grown to support winter cow inventories. It may be attractive to produce oilseeds on hay acreage where rainfall is good and other markets for hay are not attractive. At most, 10 million acres of hay land may be available for oil seeds.

Most of the CRP land is located in the Great Plains and some portion of that could be suitable to oilseed crops. The types of CRP that are most suitable for conversion to oil seeds are those acres in three categories:

Table 16. Potential CRP acres for Oilseeds

\begin{tabular}{|l|l|c|}
\hline Code & CRP Use & Acreage Enrolled \\
\hline CP01 & Introduced Grasses and Legumes & $4,229,575$ \\
\hline CP02 & Native Grasses & $6,225,279$ \\
\hline \hline CP10 & Existing Grasses and Legumes & $14,941,153$ \\
\hline
\end{tabular}

Most of the acreage in the CRP program was enrolled in 1998 (18.5 million acres) and as a result, will not be available until after 2008. A large part of that acreage was converted from wheat. If biomass oil demand expands, then perhaps as much as half of the 18.5 million acres released may be moved into canola or sunflower so long as these crops are drill seeded or planted and harvested in some other manner that minimizes soil disturbances.

Table 17 provides an optimistic estimate of near term expansion potential for vegetable oils. Actual new oil supplies will be limited by the availability of investment capital in new crushing facilities, particularly for the supplies shown for CRP land conversion, since this land will not be available until after 2008. Somewhere between 1,000 and 1,200 million new gallons of oil is a more reasonable estimate for 2016.

The combined total of 1.7 billion gallons of existing oils available for energy use coupled with the new supply potential of 1.8 billion gallons, provides a sum of 3.4 million gallons of biomass oils or 3.5 billion gallons of biodiesel. B5 remains a viable fuel through 2015. Of course, growing demand assumes either incentives or mandates are used to create the market given the price structure of oils compared to diesel fuel. 
Table 17. Near Term Growth Potential in Vegetable Oils

\begin{tabular}{|l|l|l|}
\hline $2002-2016$ & $\begin{array}{l}\text { Pounds } \\
\text { Millions }\end{array}$ & $\begin{array}{l}\text { Gallons } \\
\text { Millions }\end{array}$ \\
\hline Soybeans & 3,337 & 433 \\
\hline Canola \& Sunflower displacing wheat & 5,467 & 710 \\
\hline Canola Sunflower on CRP land & 5,056 & 657 \\
\hline \hline Total & 13,860 & 1800 \\
\hline
\end{tabular}

Table 18. Highway Diesel Market Penetration 2015

\begin{tabular}{|l|l|l|}
\hline \multicolumn{1}{|l|}{} & 2001 & 2015 \\
\hline \hline Biomass oil & 1.6 & 3.4 \\
\hline \hline Biodiesel & 1.7 & 3.5 \\
\hline \hline Percent of Highway Demand & 5.1 & 6.8 \\
\hline
\end{tabular}

\subsubsection{Slow Growth in Available Animal Fats and Grease Supplies}

At the beginning of this discussion we dismissed animal fats and greases because these feedstocks did not respond to changes in demand for biomass oils for energy. On the other hand, markets do not stagnate.

Yellow grease supplies are growing at an average annual rate of $1 \%$ per year. ${ }^{34}$ Domestic demand for yellow grease in animal feeds is growing at a rate of $1.2 \%$ per year. It is unlikely that yellow grease supplies will contribute any more to future markets than they do today, as demand is growing faster than supplies.

The supply of inedible tallow and greases has been increasing at $0.4 \%$ per year over the last five years. The domestic demand has been falling at the rate of $0.5 \%$ per year. By 2016, inedible tallow supplies could increase by 58 million gallons. Similarly, edible tallow production has been rising at the rate of $1.4 \%$ per year, while domestic demand for edible tallow has been falling at the rate of $1.3 \%$ per year. The estimated increase in edible tallow supplies by 2016 is 68 million gallons per year. A large unknown for these feedstocks revolves around BSE policies and their impacts on this market. Worst-case scenario would be that all the tallow produced could be available for energy use if banned in other markets. This quantity represents 8 billion pounds or approximately 1 billion gallons of biomass oils.

Both the supply and the domestic demand for lard have been falling slightly over the last five years, with demand falling slightly faster than supply. The estimated increase in the future supply of lard is only 7 million gallons per year.

\footnotetext{
${ }^{34}$ Rudbeck, Jim. Market Report 2001. Render, April 2002. pp. 10-15. Data presented also includes data for lard, edible tallow, inedible tallow, yellow grease and other fats and greases.
} 
The supply of other greases and trap grease is assumed to remain constant over time lacking any good information about these sources. Thus, animal fats and greases will only grow by 133 million gallons by 2016 in the absence of any significant regulatory changes in these markets.

Other minor oil seeds such as cottonseed, linseed (flax), and rape will not increase unless demand for the primary product (cotton for example) increases. Corn oil is the one exception, and technology to extract small amounts of corn oil (3\%) from distillers dried grains needs to be commercialized before corn oil can make a significant impact on supplies.

\subsection{Long term Oil Expansion}

R\&D can play a significant role in the long-term expansion of biomass oil supplies. Researchers can also modify the chemical properties of biomass oils to meet energy or biobased product specifications. Some of the keys areas for expanding supplies are listed below:

- Increasing the oil content of soybeans

- Optimizing canola, mustard and sunflower varieties in new regions

- Improving pest control for minor oil seed crops

- Increase the protein content of canola and other low protein oil seeds

- Reducing farm production costs through higher yields and lower input costs per acre

- Introducing new oil crop species

- Corn oil recovery from dry ethanol mills

These research topics are listed under long-term expansion because their impact on biomass oil supplies is not likely to be measurable until after 2015. Research that begins now, or is already underway, may yield results in 3 to 7 years, and the full impact of any advancements won't be observed until another 3 to 7 years following commercialization. Investments in biomass oil research to improve crop yields and reduce production costs will require long-term federal commitment and a clear economic environment that favors bringing successful products to commercialization. If the economics are not favorable, e.g., no incentive that creates demand for biomass oils, then promising discoveries will not be commercialized.

USDA and seed company researchers (Monsanto, Pioneer) have been developing soybean seeds that yield more oil per ton of seeds. Efforts so far have shown only modest success, adding a couple of percent to the oil content. Researchers have been far more successful modifying the types of fatty acids present in soybean oil; improving its stability and suitability for fuels by reducing linolenic acid content. But even a small increase in oil content, say $2 \%$, can yield large increases in oil supplies from almost 75 million acres of soybean cropland.

$$
\begin{gathered}
\text { Total increase in soy oil }=75 \mathrm{MM} \text { Acres } * 37.8 \mathrm{bu} / \mathrm{A} * 60 \mathrm{lb} / \mathrm{bu} * 2 \% \text { oil increase } \\
=3.4 \mathrm{billion} \mathrm{lbs}=422 \text { million gallons soy oil }
\end{gathered}
$$

Canola is grown across the northern tier of states while soybeans are grown in the Midwest and the South. Sunflower production is concentrated in the Great Plains. Expanding canola and 
sunflowers beyond their current geographical regions will require breeding trials to identify and optimize the best varieties for the new areas. Also, improving pest control technology would improve canola yields. Fewer pesticides are registered for canola use in the United States than in Canada and insect infestations reduce crop yields. Ironically, the original breeding stock for canola, rapeseed, has good pest resistance because its stems, leaves and seed meals contain glucosinolates, which are naturally occurring pesticides. Removing the glucosinolates from the meals was necessary to make the meals palatable for livestock, but that leaves the seeds vulnerable to insects. Controlling where the glucosinolates appear in the crop (steams, leaves and pods but not seed meal) may reduce the need for pesticides in canola crops and other low glucosinolate varieties such as the Canadian hybrid mustards Arid and Amulet.

There are a large number of new types of oil crops being developed in Asia, Africa and elsewhere. Crops that are native to temperate zones may be suitable for production in the United States. A significant amount of research is required to introduce and adapt any new crop and large acreage production will be decades off for these crops. Not only must the crops be adopted, but markets for their meal byproducts and other byproducts must also be developed. This tends to be a very complex and expensive process that requires careful consideration. What is successful in another country does not always translate well into U.S. production systems.

OBP began a breeding program to develop hybrid mustard and rapeseed varieties in 1998 . The oil was optimized for biodiesel production ( $98 \%$ monounsaturated fatty acids, $40 \%$ oil content) while the meal was being optimized for the organic pesticide markets. The oilseed meals exhibited a variety of pesticide qualities: some controlled weeds, others controlled insects, and even others could be used as fungicides or soil sterilizers. A pesticide must be registered for a specific crop and pest for use in the United States. In order to provide the necessary information, a large number of research trials must be conducted to determine the optimal meal for the target pest, the optimal concentration of glucosinolates (the pesticide component of the meal), and the optimal application rate and form for the pesticide. Once this set of variables is established, environmental and toxicity data must be generated for EPA registration. It is a long and complex process that requires a pesticide firm as an industrial partner. The DOE program was limited to developing a variety of hybrids with high glucosinolate levels, but did not begin the optimization process for crop trials. The cost of developing a large number of varieties, or even one variety optimized for several crops is high and the resulting amount of oil from that limited effort was not deemed high enough to justify further DOE investments.

In a more futuristic manner, biomass oils can be produced from molds and yeasts that do not require photosynthesis and thus, do not require land. These can be produced in self-contained environments, under controlled conditions using inexpensive biomass substrates as feedstocks. These organisms can produce $20 \%$ to $40 \%$ of their dry mass as oils, with compositions that are similar to other vegetable oils. The DOE had a micro algae program for 20 years based on a similar concept, but land use requirements and other barriers raised production costs and reduced the practicality of this approach. The micro algae program was cancelled in $1996 .^{35}$

\footnotetext{
${ }^{35}$ Sheehan, et al. July 1998. A Look Back at the UNITED STATES Department of Energy's Aquatic Species Program: Biodiesel from Algae Close-Out Report. NREL/TP-580-24190.
} 
If a technology could be developed to extract corn oil from dry ethanol mills in a cost effective manner, approximately 736 million gallons of corn oil could be recovered for use in biomass oil markets if the ethanol industry grows to 5 billion gallons.

\subsection{Ultimate Supply Potential}

Policy makers want to know what the ultimate or maximum supply potential could be. This is an artificial number with respect to an agricultural product because the agricultural industry will continually remake itself to satisfy a growing demand; unlike fossil reserves, which are typically finite and decline over time. People try to forecast the industry with static land use and export patterns, but miss the key strength of this sector-farmers can chose to grow something different each year. Huge segments of the agricultural industry rise and fall and are replaced with new crops over time. If this country wants to expand oilseed production, it can.

When we look to ethanol, we see an industry that the pundits claimed would never exceed 500 million gallons in 1979 now exceeding 3 billion gallons per year and with plans to grow to 5 billion gallons by 2012. Most of the expansion in the corn ethanol industry has occurred since 1986, but corn acreage only expanded by 3 million acres. In addition, corn costs are no higher now than they were 30 years ago when this country began its investment in corn ethanol. All this while real food prices fell over the last 30 years.

There is no reason why the oil seed industry should not face equal success even at the same time as the corn industry grows. And it is just as obvious that we cannot accurately predict exactly how that growth will occur. Even though agricultural models all predict increasing prices for oil (which are an artifact of demand increases in a static model), it is highly unlikely to occur in the long run. Models can only extrapolate existing trends and cannot predict major shifts in industry, such as land moving out of soy and into high oil content oil seeds. Oilseed breeding and optimization are in their infancy, and significant gains can be made with these crops, as we saw with corn. Predictions of increasing land use (see below) are also unlikely to occur at the scale predicted, although some growth is inevitable.

For those readers who need to see how a growing oilseed industry may occur, some land use conversion scenarios were developed to show various strategies. All wheat exports could be displaced, freeing up as much as 30 million acres of land. Assuming this land is planted in canola with yields increasing from 1,455 pounds per acre today to at least 2,000 pounds adds over 3.1 billion gallons of biomass oil. If CRP acreage and some minor pasture land conversion occur, future oil production could add another 3.1 billion gallons per year. If soybean land is converted to higher yielding oil seeds (assuming a reduced demand for soybean exports and an increasing demand for oils) then up to 30 million acres of land could be added again to oilseed supplies, at considerably higher yields than we assume for canola grown on wheat land for yet another 3.1 to 4.0 billion gallons per year. Soybean acreage is highly productive land. Soybean and oil seed yields per acre could increase by $25 \%$ or more with good breeding and improved management systems, raising the total potential for biomass oil production to nearly 10 billion gallons per year. 
The rate of land conversion and ultimate size of the future oil seed industry is more a function of how much the taxpayers willing to pay than what could the agricultural industry ultimately produce. The majority of biomass oils have prices that exceed $\$ 1.00$ per gallon so incentives will be required bridge the difference between biomass oil prices and petroleum distillate prices. It is very likely that petroleum prices will begin to rise in the next decade, although EIA models do not show much price growth in real terms. Crude oil production levels may peak and begin to fall off during this period. There are an increasing number of respectable predictions from major oil companies that support this view. Restated oil reserves have also reduced the pool of recoverable reserves for crude oil. Gradually rising oil prices may allow the incentives to decline over time as the price differentials close.

As crude oil prices impact petrochemical products, oleochemicals may regain some fraction of their previous market share. This may offer significant expansion of oleochemical and fuel production opportunities that could drive expanded methyl ester capacity.

And last but not least, we should address cropland competition with cellulosic crops, such as switchgrass or poplar. The key to commercializing cellulosic crops is to minimize their cost but still provide farmers with enough incentive to produce them. Most models of show the cellulosic crops competing with wheat, hay and low value crops similar to canola and sunflower crops. Farmers will need to determine which crops offer the highest returns and the lowest risks of market failure. Some modeling with various oilseed incentives would shed more light on this OBP program issue.

In summary, biomass oil crops offer an avenue towards displacing as much as 10 billion gallons of petroleum per year by 2030 through domestic production. Crops are available and offer significant optimization potential. Oil extraction and conversion technologies are commercial and offer cost savings to the public as economies of scale expand. Biomass oil's ease of use and the number of potential uses offers easy access to petroleum markets and low hurdles for petroleum displacement potential. Low blends of $10 \%$ or less offer affordable market products despite high feedstock costs and biomass-oil fuel prices. In short, there is no reason not to optimize this biomass industry to the extent possible to achieve a larger fraction of petroleum displacement and energy independence. 


\section{PRODUCTION OF BIOMASS OILS AND FUELS}

There are several key steps to produce biomass oils and their derivative fuels such as biodieselproducing the seed, crushing the oil from the seed, pretreating the oil into specific commercial grades, and converting biomass oils into derivatives such as biodiesel or bio-distillates. For oil plants other than seeds, the basic steps remain the same although the processes and the terminology may vary. Animal fat production has similar steps although animals and meat are produced, meat byproducts are rendered into meals and fats, followed by pretreatment into grades and if desired, conversion. Recycled greases are typically collected and pretreated and then can be used as is or converted into derivative fuels. Regardless of the source of the oil or fat, these basic steps are involved and add costs to the biomass oil product.

\subsection{Seed Production}

Seed production costs vary across a broad spectrum depending on the quality of land, the type of seed, climate, inputs, pest management practices and the weather. ${ }^{36}$ In 1997 (most recent survey data) soybean production costs ranged from a low of $\$ 2.13$ cents per bushel to over $\$ 6.47$ per bushel. Soybean production costs averaged $\$ 137.77$ per acre; the gross value of the soybeans averaged $\$ 278.77$. Soybeans are second only to corn in their income producing potential for farmers.

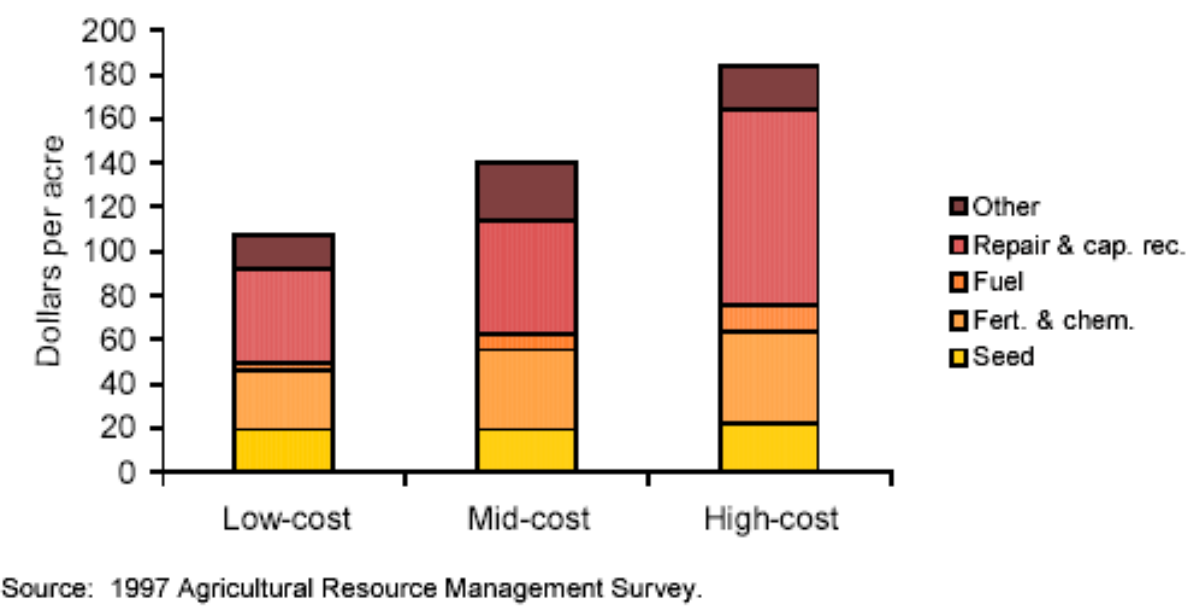

Figure 16. Production costs per acre, Soybeans 1997.

Production costs per bushel have two components: cost per acre and yield. Equipment costs, chemicals, and seed comprise over $60 \%$ of total production costs. The United States has relatively low operating and transportation costs but high land costs, which have been depressing the competitive advantage in recent years. Improvements in pesticide resistant varieties have reduced input costs and raised yields over the last five years. Yields are maximized when soybeans are grown in rotation with other crops.

\footnotetext{
${ }^{36}$ Foreman, Linda and Janet Livezey. March 2002. Characteristics and Production Costs of U.S. Soybean Farms. USDA/ERS Statistical Bulletin No. 974-4.
} 


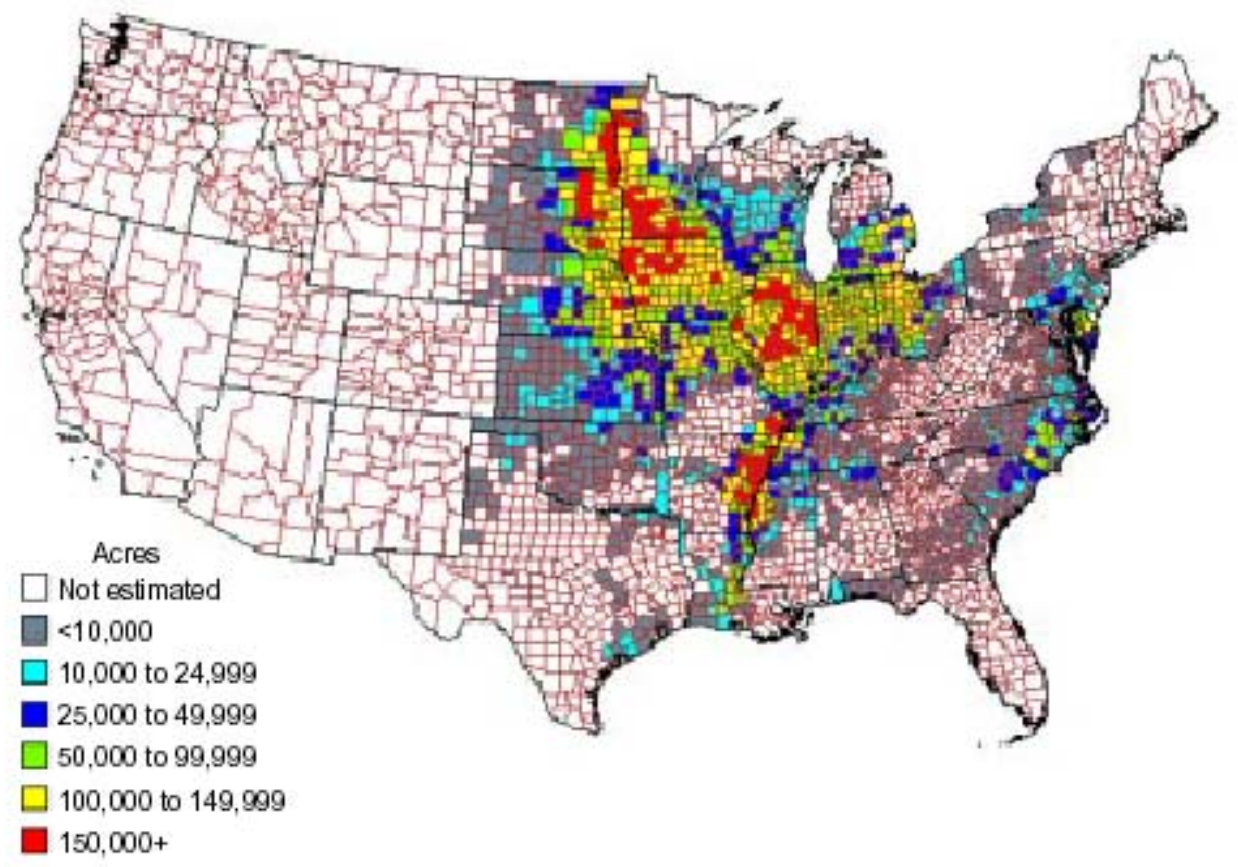

Source: National Agricultural Statistics Service, USDA.

Figure 17. United States Soybean Production, 2001.

Compared to soybeans, all other oilseed crops that could expand with demand are minor (Table 13). Their yields have not been optimized for broad scale production in the United States nor have their management practices been optimized.

Table 19. Oil Content of Yeasts and Molds

\begin{tabular}{|l|l|l|l|}
\hline Yeasts & $\begin{array}{l}\text { Fat Content } \\
\%\end{array}$ & Molds & $\begin{array}{l}\text { Fat Content } \\
\%\end{array}$ \\
\hline \hline Candida lipolytica & 36 & Eutomophthora virulenta & 26 \\
\hline \hline Trichosporum cutaneum & 45 & Aspergillus flavus & 28 \\
\hline Candida curvata & 58 & Phytium ultimum & 49 \\
\hline \hline Lipomycens lipferus & 63 & Fusarium bulbigenum & 50 \\
\hline \hline Endomyces vernalis & 65 & Aspergillus fischeri & 53 \\
\hline \hline Rhodotorula glutinis & 71 & Penicillium lilacinum & 56 \\
\hline & & Mucor circinecelloides & 65 \\
\hline
\end{tabular}

There are a number of novel feedstocks that do not require land-yeasts, bacteria, fungi, and molds. Yeasts and molds can contain up to $70 \%$ lipids. Arthrobacter AK 19, a soil bacterium, can produce up to $78.3 \%$ of its cell dry matter as oil using short chain hydrocarbons (similar to what are found in pyrolysis oils) as substrates. The presence of lipases (fat splitting enzymes) results in various combinations of mono, di-, and triglycerides and free fatty acids in these oils. The oils contain mostly oleic and palmitic acids similar to other vegetable oils.

Fat producing organisms are grown in a carbohydrate rich environment. The fat producing portion of their growth cycle is triggered by depriving them of nutrients, typically nitrogen-based 
nutrients. Until that point, nitrogen based fertilizer is required to promote population growth. Microorganisms are regarded as fat-producers if they contain ATP that enables them to quickly produce acetyl coenzyme A. Conversion rates using glucose feedstocks will rarely exceed $25 \%$ (glucose to fat). The key to using microorganisms for oil production is to identify low cost feedstocks for the microorganisms and optimize their conversion efficiency.

Most testing has used glucose and other expensive substrates, which limit economics. Other sugars and cellulosic feedstocks have not been explored in as much detail. Microorganisms utilizing biomass substrates available for $\$ 50$ per ton ( 2.5 cents per pound) may produce a pound of oil for as little as 10 cents per pound (feedstock cost only) if the entire biomass could be converted. More realistically, a microorganism may only feed on select fractions of biomass substrates. However, if oil could be extracted without leaving poisonous residues (super critical $\mathrm{CO}_{2}$ extraction for example), then the substrates could be inoculated again with different types of organisms better suited to the remaining portions of the biomass. In a slightly different vein, the lignocellulosic wastes from biomass ethanol production may be suitable substrates for microorganism oil production, eliminating or reducing drying costs. Other food, paper and animal processing waste streams may be suitable for this approach.

Most microorganisms have not been optimized for fat production, although EERE invested significant resources in a micro algae program from 1977 through 1996. Micro algae production suffered from a number of failings. First and foremost, the micro algae was grown to produce fat and a byproduct animal feed. The higher the fraction of fat, the higher the percentage of total production costs allocated to the fat. Thus, it was not clear that fat production costs could be minimized through this system - but perhaps oil supplies could be expanded. Internal NREL reports projected that fat production costs from microalgae would be on par with the cost of producing soybean oil. Second, large amounts of land and water are required for these photosynthesis dependent systems. Some researchers postulated that large tracts of the American Southwest Desert could be converted into raceway systems using underlying brackish water. The environmental impacts of these systems were never fully considered. These open-air systems would contain genetically modified micro algae; vulnerable to infestation and crosses with wild algae, exposure to migratory bird populations and flash flood events. Last but not least, these systems would need to be located in close proximity to coal fired power plants for easy access to $\mathrm{CO}_{2}$ (to enhance growth) and other pollutants that could be used as nutrients. Insufficient flat land with cheap water (the West has very little "cheap" water), near power plants was readily accessible for these systems.

The concept of using molds, yeasts, fungi and bacteria offers some of the same challenges that micro algae systems posed (nutrients, costs, microorganism and system optimization), but do not require large amounts of water (using water recycling) or land. In fact, using genetically modified organisms in a self contained environment offers minimal public safety risks. The carbohydrate fraction of the organisms can even be recycled back into the system to prevent release and to provide key nutrients for growth. Because these organisms are easy to modify, a number of high value chemicals could be coproduced in these systems, hopefully producing enough profit to make future investments in these systems viable. 
The research goal for these systems should not be to produce oil at the same cost as petroleum diesel or less (too heroic) but to produce oils at a cost less than the cost of producing soy oil. These opportunities should be explored in more detail.

\subsection{Vegetable Oil Extraction}

The diagram below provides a basic overview of the types of processes involved in producing various grades of vegetable oil. Chapter 5 of the Life Cycle Inventory of Biodiesel and Petroleum Diesel for Use in an Urban Bus has detailed soy oil production processes, from seed production through refining and degumming (RD oil) including biodiesel production, so that discussion will not be repeated here. ${ }^{37}$

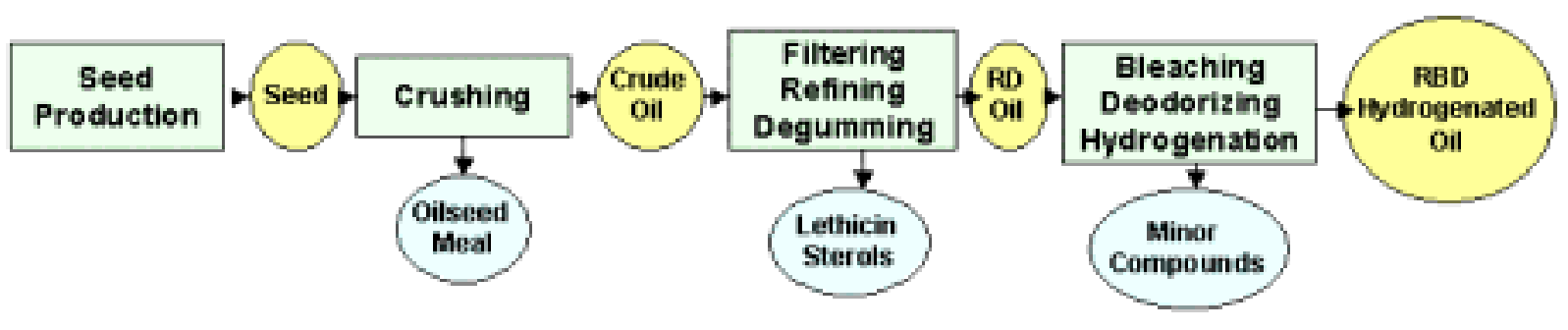

Figure 18. Basic Overview of Vegetable Oil Production

Bleaching involves moving the oils through an activated carbon bed or mixing with fuller's earth and then filtering. Deodorizing is a vacuum distillation process that removes light ends, color bodies and other minor contaminants. Hydrogenation is typically done with nickel catalysts similar to petroleum refining. The refined bleached deodorized oils (RBD) are typically used for food or for oleochemical processing where contaminants need to be controlled to protect catalysts and systems from fouling. Biodiesel benefits from oils that have been refined (removes free fatty acids that reduce yields) and degummed (removes phosphatides that raise phosphorus content of fuels and could deactivate exhaust catalysts). Further processing of vegetable oils is not generally necessary (Table 20). The refining process is conducted concurrently with degumming in some circumstances since $\mathrm{NaOH}$ is used to remove free fatty acids as soaps and combined with hot water to swell phosphatides that can be filtered out.

Crown Iron Works has developed a continuous $\mathrm{CO}_{2}$ extraction technology for soybean crushing that has high yields $(98 \%+)$, good moisture tolerance (up to $11 \%$ ), and is suitable for small-scale plants. Capital costs are purported to be modest. The resulting oil quality is similar to RBD oils, which saves at least 2 to 5 cents per pound (15 to 38 cents per gallon) on pretreatment costs for biodiesel or food products. This technology has currently been demonstrated at a pilot scale for up to 8 hours and Crown is working with industrial partners to demonstrate the technology on a larger, more continuous scale in the next year. If super critical $\mathrm{CO}_{2}$ can solubilize methanol with the oil, some opportunities may exist to combine biodiesel production with $\mathrm{CO}_{2}$-oil extraction.

\footnotetext{
${ }^{37}$ Sheehan, John et al. 1998. Life Cycle Inventory of Biodiesel and Petroleum Diesel for Use in an Urban Bus. NREL/SR-580-24089 UC Category 1503. http://www.ott.doe.gov/biofuels/lifecycle_pdf.html
} 
Table 20. Average Compositions for Crude and Refined Soybean $\mathrm{Oil}^{38}$

\begin{tabular}{||c|c|c|}
\hline Component & Crude Oil & Refined Oil \\
\hline Triglycerides (\%) & $95-97$ & $>99$ \\
\hline \hline Phosphatides (\%) & $1.5-2.5$ & $0.003-0.045$ \\
\hline \hline Unsaponifiable matter (\%) & 1.6 & 0.3 \\
\hline Plant sterols (\%) & 0.33 & 0.13 \\
\hline Tocopherols (\%) & $0.15-0.21$ & $0.11-0.18$ \\
\hline Hydrocarbons (squalene) (\%) & 0.014 & 0.01 \\
\hline Free fatty acids (\%) & $0.3-0.7$ & $<0.05$ \\
\hline Trace metals & & \\
\hline Iron (ppm) & 1.3 & $0.1-0.3$ \\
\hline \hline Copper (ppm) & $0.03-0.05$ & $0.02-0.06$ \\
\hline
\end{tabular}

\subsection{Rendering Technologies}

Renderers can be integrated with USDA slaughter houses (better known as meat packing plants) or they can be independent. The rendering that occurs on site at the meat packer produces edible fats. Live animals come in and all the parts that aren't sold as meat or hides are rendered down less than 8 hours later into fats and greases, or meat, blood, feather and bone meals. Independent renderers have more diverse supply chains, including meat packers that don't have on site rendering, grocery stores, butcher shops, livestock mortality, etc. Material that comes in the door is dead. The process for meat wastes is the same regardless of the source of feedstock (Figure 19).

The meat, organs, and bone wastes are cooked down until all the fats become liquid and then the liquids are separated from the solid materials (Figure 20) via mechanical presses or solvent extraction. The solids become the various meals that are used as animal feeds.

High-quality fats from specific parts of the animals are typically separated before processing and sent to separate cookers for identify preservation. Lower quality fats are sent to a main cooker. Cooking temperatures are tightly controlled to prevent discoloring the fats. Water is also removed under vacuum to prevent the fats from hydrolyzing, which leads to high free fatty acid content. Solids and gums are filtered out. For a good overview of the industry and its technologies see The Original Recycler ${ }^{39}$ or Better Rendering ${ }^{40}$ for a historical perspective.

\footnotetext{
${ }^{38}$ Sipos, Endre F. and Bernard F. Szuhaj, "Soybean Oil" Chapter 11, Bailey's Industrial Oil \& Fat Products, Vol. 2 Edible Oil \& Fat Products: Oils and Oil Seeds. Fifth Ed. John Wiley \& Sons.

${ }^{39}$ Published by the Fats and Protein Research Foundation, The Animal Protein Producers Industry, and the National Renderers Association. 1996.

${ }^{40}$ A Manual Prepared by Proctor and Gamble, 1949.
} 


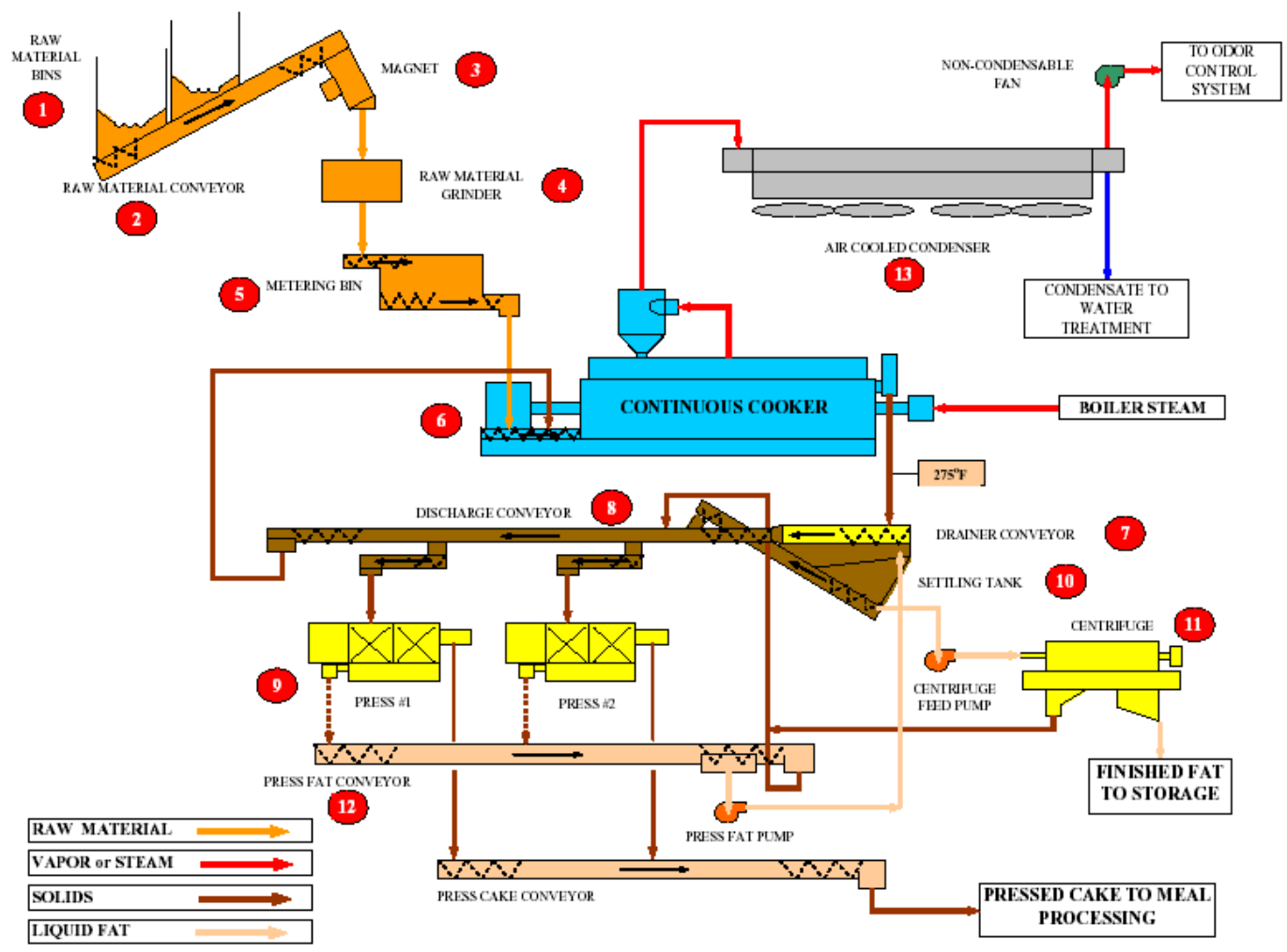

Figure 19. Rendering Process Flow Diagram ${ }^{41}$

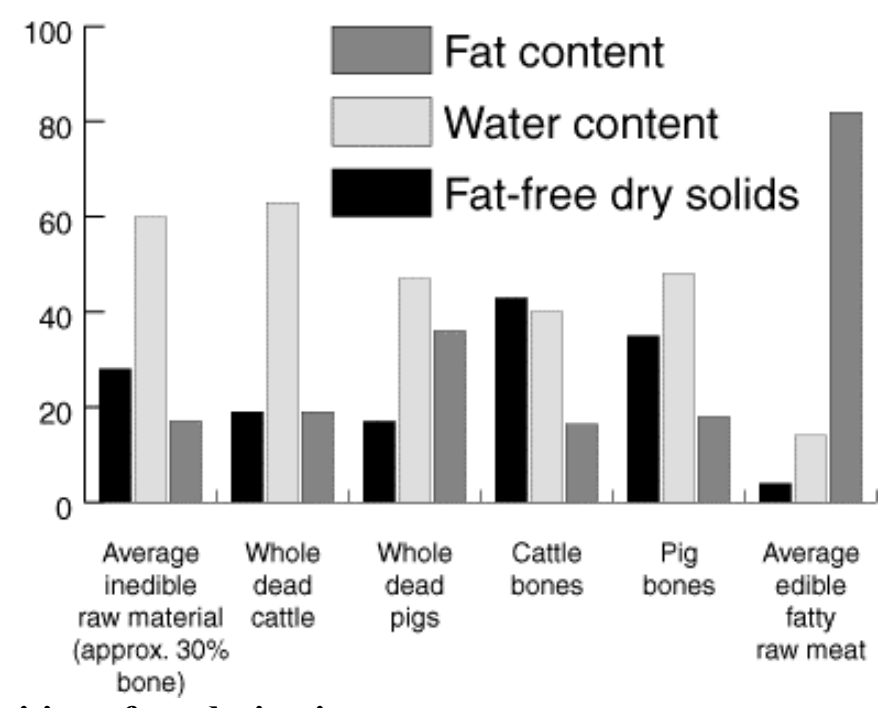

Figure 20. Composition of rendering inputs

The fats can be sold as is, or subjected to further pretreatments depending on the grade of material demanded by purchasers (Table 21). Fats destined for food and oleochemical production

\footnotetext{
${ }^{41}$ National Renderer's Association, http://www.renderers.org/Continuous_rendering_system/index.htm
} 
can undergo refining, degumming, bleaching, and deodorizing similar to vegetable oils. The inputs for these processes are generally higher quality fats that have low color, free fatty acids, and unsaponified contents to begin with, so yield losses are low.

Because rendering is a cooking process, it is energy intensive. Meal must be cooked to control pathogens, but if some other process such as the super critical $\mathrm{CO}_{2}$ process described in the previous section could be effective in removing fats and greases, then some cost savings might be realized by the rendering industry. Additional benefits might be realized if the fat and grease extracted by the $\mathrm{CO}_{2}$ process are as clean as the RBD soy oil produced from the experiments Crown conducted with soy.

Table 21. American Fats and Oils Association Specifications for Tallow and Greases

\begin{tabular}{|c|c|c|c|c|c|c|}
\hline \multicolumn{2}{|r|}{ Grades } & \multicolumn{5}{|c|}{ Specifications $^{42}$} \\
\hline & & \multirow{2}{*}{$\begin{array}{c}\begin{array}{c}\text { TITRE } \\
\text { MIN } \\
{ }^{\circ} \mathrm{C}\end{array} \\
41.0\end{array}$} & \multirow{2}{*}{$\begin{array}{c}\begin{array}{l}\text { FFA } \\
\max \end{array} \\
0.75\end{array}$} & \multirow{2}{*}{$\begin{array}{c}\begin{array}{c}\text { FAC } \\
\max \end{array} \\
3\end{array}$} & \multirow{2}{*}{$\begin{array}{c}\begin{array}{c}\mathrm{R} \& \mathrm{~B} \\
\max \end{array} \\
\text { none }\end{array}$} & \multirow{2}{*}{$\begin{array}{c}\text { MIU } \\
*\end{array}$} \\
\hline 1) & Edible tallow & & & & & \\
\hline 2) & Lard (edible) & 38.0 & 0.50 & $* *$ & none & $*$ \\
\hline 3) & Top white tallow & 41.0 & 2 & 5 & 0.5 & 1 \\
\hline 4) & All beef packer tallow & 42.0 & 2 & none & 0.5 & 1 \\
\hline 5) & Extra fancy tallow & 41.0 & 3 & 5 & none & 1 \\
\hline 6) & Fancy tallow & 40.5 & 4 & 7 & none & 1 \\
\hline 7) & Bleachable fancy tallow & 40.5 & 4 & none & 1.5 & 1 \\
\hline 8) & Prime tallow & 40.5 & 6 & 13-11B & none & 1 \\
\hline 9) & Special tallow & 40.0 & 10 & 21 & none & 1 \\
\hline 10) & No 2 tallow & 40.0 & 35 & none & none & 2 \\
\hline 11) & A tallow & 36.0 & 15 & 39 & none & 2 \\
\hline 12) & Choice white grease & 36.0 & 4 & 13-11B & none & 1 \\
\hline 13) & Yellow grease & $* * *$ & 15 & 39 & none & 2 \\
\hline & $\begin{array}{l}\text { ture maximum } 0.20 \% \text {. I } \\
\text { ibond colour } 51 / 4 \text { inch } \\
\text { tre minimum, when requ }\end{array}$ & $\begin{array}{l}\text { ties } \mathrm{m} \\
\text { ed. La } \\
\text { tiated }\end{array}$ & $\begin{array}{l}0.05^{\circ} \\
\text { ide va }\end{array}$ & $\begin{array}{l}4.0 \mathrm{M} \\
\mathrm{d} \text { sell }\end{array}$ & $\max$ & basis. \\
\hline
\end{tabular}

\footnotetext{
${ }^{42}$ Titer is a measure of the melting point of the fat. FFA is free fatty acid content in percentage of weight. FAC and
} $\mathrm{R} \& \mathrm{G}$ are measures of color. MIU stands for Moisture, Impurities, and Unsaponified material. 


\subsection{Recycled Grease Technologies}

As meat packing has become more corporate and consolidated in this country, small independent renderers have shifted to recycling used cooking oils from restaurants, institutional facilities, and food processors. These greases are typically good quality for animal feed and energy purposes and undergo simple filtration and dewatering. The grade is dependent on free fatty acid (FFA) and "moisture, impurities, and unsaponified material" (MIU) content and the color tends to be fairly dark. FFA tends to vary seasonally, rising in the summer as the sun "cooks" the grease stored in outside containers (particularly when rain water is present) naturally hydrolyzing the fat. FFA ranges from $1.5 \%$ from food processors, to $4 \%$ FFA from restaurants in the winter, to as high as $10 \%$ or $15 \%$ FFA in the summer (depending on how frequently the grease is collected).

Brown greases may be used cooking oils that have decomposed more than the norm, they may contain greases directly from the griddle, or may be composed of greases that were overcooked at renderers. In some cases, brown greases may contain trap greases. Trap greases are typically banned as animal feeds based on their source, but some blending with other greases is suspected to occur in minor amounts. It is difficult to distinguish sources of grease without extensive testing for specific contaminants such as cleaning products.

Trap greases are collected in concrete tanks under kitchen waste water lines. They are not connected with sewage or rest room waste lines. Trap grease is collected to prevent clogs in sewage lines that can cause waste to back up into homes and businesses. Most municipal regulatory agencies have regulations that govern the size of traps (based the number of meals prepared) and the frequency for emptying them. Septic firms and trap grease haulers typically pump out the larger traps. Employees generally clean small traps. The grease is emptied into buckets or other containers and placed in the regular trash. Trap grease can range from $40 \% \mathrm{FFA}$ to $100 \%$ FFA and contain large amounts of water and solids. Because triglycerides degrade into diglycerides and monoglycerides, emulsions are frequently encountered. Firms that remove trap grease must pay disposal fees at landfills or city sanitation facilities. The city sanitation facilities must stabilize the material and haul it to a landfill where they pay disposal fees. In these times of budget constraints, many sanitation plants are refusing trap greases.

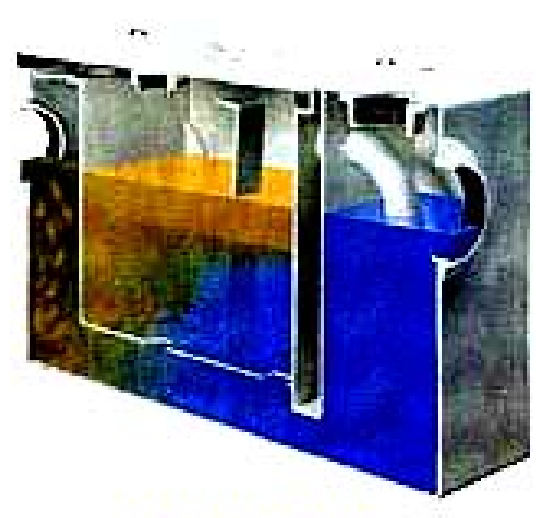

Grease Trap

\begin{abstract}
A grease trap works by slowing down the flow of warm/hot greasy water and allowing it to cool. As the water cools the grease and oil separate and float to the top of the grease trap. The cooler water (less grease) continues to flow down the pipe to the sewer. The grease is actually trapped by baffles, which cover the inlet and outlet of the tank, preventing grease from flowing out of the trap.
\end{abstract}

Figure 21. Grease Trap System Overview

To recover trap grease for energy purposes requires the development of collection and pretreatment infrastructure. Trap grease infrastructure includes the construction of a liquid waste 
receiving station. The water and the grease are separated using both physical and chemical means. The separated trap grease must be filtered and dewatered for use as a boiler fuel. Most waste receiving stations will charge a tipping fee that can reduce the costs of pretreating the trap grease, leaving the cleaned, dried feedstock relatively cheap to use for energy. Trap grease are used as a boiler fuels and anaerobic digester feedstocks at several United States locations.

For biodiesel, production trap grease will need to be deodorized, which should remove a significant portion of the contaminants. Fine grit must also be removed to reduce wear and tear on equipment. Further removal of contaminants using bleaching or other processes will depend on what remains behind and whether it causes the biodiesel to fail ASTM standards.

Pretreatment technologies are well understood when the feedstocks are vegetable oils or animal fats. There is no information on how efficient these processes might be, what potential for fouling may be present, or what the costs and resulting quality will be when trap greases are used. Biodiesel producers could blend these feedstocks into other, low FFA, biomass oil feedstocks up to the FFA limits of their technologies, so long as the resulting biodiesel meets ASTM standards.

To process trap grease directly into biodiesel, it must be fully hydrolyzed, dried and then converted into biodiesel with counter current sulfuric acid and methanol in some variation of the Emery Colgate technology. Yields of fatty acids to methyl esters should approach $99 \%$ with this process. Total yields will be less depending on the quality of the grease as received and pretreatment losses.

\subsection{Biodiesel Production Technology}

Fatty acid methyl esters are one of two primary platform chemicals produced by the oleochemical industry (Figure 22). Methyl esters from triglycerides are produced using inexpensive base catalysts $(\mathrm{NaOH}$ or $\mathrm{KOH})$ and methanol at low temperatures $\left(60^{\circ} \mathrm{C}\right.$ to $\left.80^{\circ} \mathrm{C}\right)$ and pressures (1.4 atm) in both batch and continuous systems (Figure 23). The other major platform chemical, fatty acids, can also be used to produce methyl esters. Fats are hydrolyzed to free fatty acids and glycerol in one of two ways: 1) continuous, high pressure, counter current systems at 20 to 60 bar and $250^{\circ} \mathrm{C}$ with or without catalysts, which are typically zinc oxide, lime, or magnesium oxide added to water; or 2) counter current systems at atmospheric pressure with small amounts of sulfuric/sulfonic acids in steam. Methyl esters are produced from fatty acids using strong mineral acids, such as sulfuric acid or a sulfonated ion exchange resin, and methanol in counter current systems at $80^{\circ} \mathrm{C}$ to $85^{\circ} \mathrm{C}$ under mild pressures. If a feedstock contains both triglycerides and free fatty acids, acid esterification is performed on the entire feedstock first, followed by transesterification to convert the remaining triglycerides. Water management is a key to high yields and low processing problems. Yields of glycerides and fatty acids to esters for all processes generally exceed $97 \%$ and can reach $99 \%$ with careful management of equilibrium conditions. 


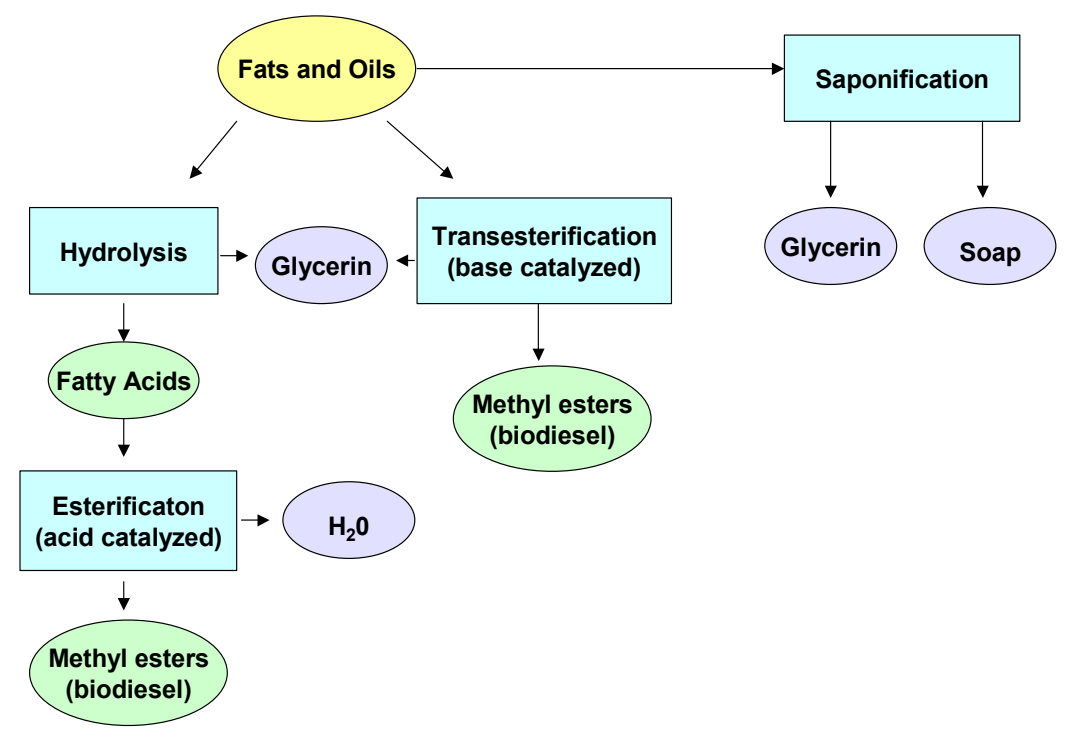

Figure 22. Primary Oleochemical Platform Pathways ${ }^{43}$

As temperatures and pressures increase, the transesterification reaction becomes autocatalyzed. Henkle used this process with crude soy oil in the 1970's and at least one biodiesel technology provider (BDT) offers a variation of this technology for feedstocks containing FFA, "the more the better." Conditions may not be supercritical for methanol but may employ high enough temperatures and pressures to autocatalyze the reaction. A recent review of biodiesel technologies is provided in Table 22 .

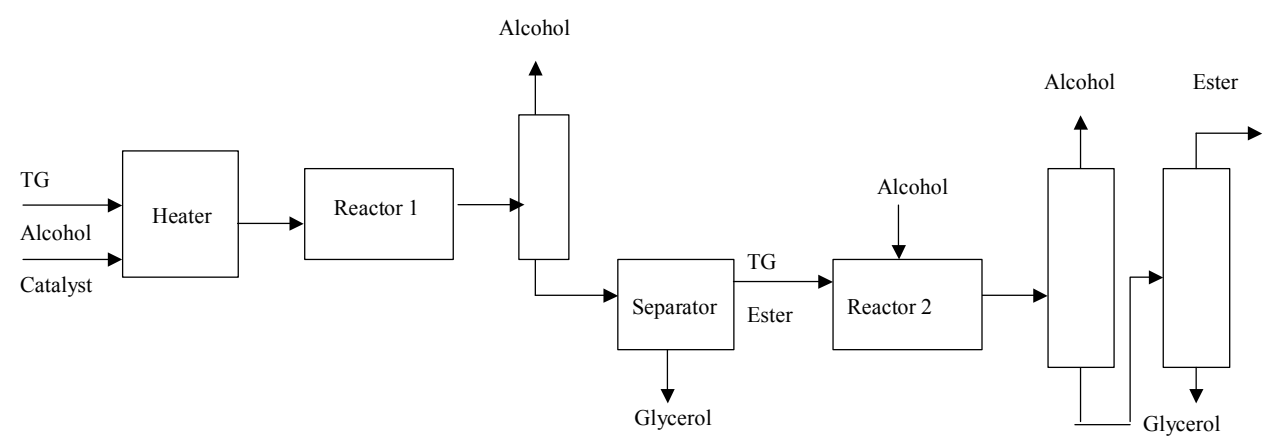

Figure 23. Plug Flow Reactor System

${ }^{43}$ Gunstone, Frank. 2001. Basic oleochemicals,oleochemical products, and new industrial oils. in Oleochemical Manufacture and Applications (Sheffield Academic Press). 
Table 22. Commercial and Precommercial Biodiesel Technologies Available, 2004

\begin{tabular}{|c|c|c|c|c|}
\hline & Ballestra & $\begin{array}{l}\text { BDT Biodiesel } \\
\text { Technologies GmbH }\end{array}$ & Biodiesel Industries & Biodiesel International \\
\hline Contact & $\begin{array}{l}\text { Giuseppe di Carpegna } \\
\text { Via Piero Portoluppi 17- } \\
\text { 20138, Milano, Italy } \\
\text { +3902 5083248 } \\
\text { giuseppe.dicarpegna@ } \\
\text { ballestra.com }\end{array}$ & $\begin{array}{l}\text { Dr. L. Kondor } \\
1130 \text { Wien, Austria } \\
\text { Hietzinger Hauptstrassse 50,+43 } 1 \\
8770553 \\
\text { dr-kondor@eunet.at }\end{array}$ & $\begin{array}{l}\text { Russell Teall } \\
\text { 435-1/2 El Sueno Road } \\
\text { Santa Barbara, CA } 93110 \\
\text { 805-689-9008 } \\
\text { rteall@aol.com }\end{array}$ & $\begin{array}{l}\text { Wilhelm Hammer } \\
\text { Ges.m.b.H. } \\
\text { Parkring } 18 \\
\text { A-8074 Grambach/Graz } \\
\text { +43 } 3164009100 \\
\text { bdi@biodiesel-intl.com }\end{array}$ \\
\hline Technology & $\begin{array}{l}\text { Continuous transesterification } \\
\text { process developed in 1980s }\end{array}$ & $\begin{array}{l}\text { Continuous 2-stage base re- } \\
\text { esterification, } 20 \mathrm{ft} \text { skid mounted }\end{array}$ & $\begin{array}{l}\text { No information, } 40 \mathrm{ft} \text { container } \\
\text { modulars }\end{array}$ & $\begin{array}{l}\text { Fully automatic PLS controlled } \\
\text { production system }\end{array}$ \\
\hline Status & Fully commercial & Commercial & Commercial & Fully commercial \\
\hline Feedstock & Vegetable and yellow grease & $\begin{array}{l}\text { Vegetable oils, animal fats, yellow } \\
\text { grease; technically unlimited FFA, } \\
\text { economic to } 10 \% \text { FFA }\end{array}$ & Vegetable oils and animal fats & $\begin{array}{l}\text { Plant oils, waste cooking oils, } \\
\text { animal fats }\end{array}$ \\
\hline Pretreatment & Oil refining module on request & $\begin{array}{l}\text { A vacuum oil purification unit is } \\
\text { available for yellow grease and } \\
\text { animal fats }\end{array}$ & $\begin{array}{l}\text { Unlimited FFA or MIU, } \\
\text { pretreatment depends on feedstock } \\
\text { quality }\end{array}$ & FFA in excess of $20 \%$ \\
\hline Processing costs & No information & $\begin{array}{l}\text { For vegetable oils: } 28.2 \text { cents per } \\
\text { gallon United States }\end{array}$ & $\begin{array}{l}\text { To be provided as part of feasibility } \\
\text { study and subject to NDA }\end{array}$ & No information \\
\hline Capacity & From $2 \mathrm{mgy}$ to $60 \mathrm{mgy}$ & $\begin{array}{l}\text { Modular units: } 0.5 \mathrm{mgy}, 1.0 \mathrm{mgy} \text {, } \\
\text { and } 1.5 \mathrm{mgy} \text {. }\end{array}$ & 3.0 mgy modular units, scaleable & No information \\
\hline Capital costs & No information & No information & $\begin{array}{l}\text { To be provided as part of feasibility } \\
\text { study and subject to NDA }\end{array}$ & No information \\
\hline Lead time & No information & Four to five months & $\begin{array}{l}\text { Three months delivery, site footprint } \\
\text { and tankage required in addition to } \\
\text { modular }\end{array}$ & No information \\
\hline Products & $\begin{array}{l}\text { ASTM and European grade } \\
\text { biodiesel, glycerin upgrading to } \\
88 \%-90 \% \text {, higher glycerol quality } \\
\text { on request }\end{array}$ & $\begin{array}{l}\text { ASTM biodiesel, } 65 \% \text { crude } \\
\text { glycerin, distilled FFA potential }\end{array}$ & $\begin{array}{l}\text { ASTM biodiesel, glycerin quality } \\
\text { subject to feasibility study and NDA }\end{array}$ & $\begin{array}{l}\text { ASTM and European quality } \\
\text { biodiesel, } 80 \% \text { glycerin, potassium } \\
\text { phosphate fertilizer }\end{array}$ \\
\hline Yield & $99.8 \%$ neutral oil to esters & $98 \%$ & $\begin{array}{l}\text { To be provided as part of feasibility } \\
\text { study and subject to NDA }\end{array}$ & $\begin{array}{l}\text { One pound raw material yields } \\
0.136 \text { gal of } \mathrm{B} 100\end{array}$ \\
\hline Warranties & No information & $\begin{array}{l}12 \text { months full warranty, spare parts } \\
\text { for } 10 \text { years guaranteed }\end{array}$ & $\begin{array}{l}\text { Manufacturers warranty ranges from } \\
\text { one year up to } 10 \text { years }\end{array}$ & No information \\
\hline
\end{tabular}

\footnotetext{
${ }^{44}$ Talley, Dick. “Biodiesel: A Compelling business for the Rendering Industry,” Render Magazine, February 2004. pp.20-21. Author's table notes: Information provided by individual technology providers and/or obtained from public literature. Please contact providers for more details or explanations.
} 
Table 22. Commercial and Precommercial Biodiesel Technologies Available, 2004

\begin{tabular}{|c|c|c|c|c|}
\hline & BioSource Fuels, LLC & BIOX Corporation & Crown Iron Works Company & Energea Biodiesel Technology \\
\hline Contact & $\begin{array}{l}\text { Michael Marquardt } \\
\text { P.O. Box } 639 \\
\text { Kenosah, WI } 53141 \\
\text { 262-859-2272 } \\
\text { mikem@,biosourcefuels.com } \\
\end{array}$ & $\begin{array}{l}\text { Tim Haig } \\
125 \text { Lakeshore Rd. East, Suite } 200 \\
\text { Oakville, Ontario Canada, L6J 1H3 } \\
\text { 905-337-4973 } \\
\text { trhaig@bioxcorp.com } \\
\end{array}$ & $\begin{array}{l}\text { Derek Masterson } \\
\text { P.O. Box 1364 } \\
\text { Minneapolis, MN 55440-1364 } \\
\text { 651-638-5443 } \\
\text { dmasterson@,crowniron.com } \\
\end{array}$ & $\begin{array}{l}\text { Mr. Herbert Prischink } \\
\text { Inkustrasse 1-7, A-3400 } \\
\text { Klosterneuburg, Austria } \\
\text { +432243440300 } \\
\text { herbert.prischink@energea.at }\end{array}$ \\
\hline Technology & $\begin{array}{l}\text { Continuous process with biodiesel } \\
\text { distillation, fully automated with } \\
\text { PLC or DCS contols }\end{array}$ & $\begin{array}{l}\text { Solvent assisted conversion } \\
\text { technology }\end{array}$ & $\begin{array}{l}\text { Continuous process for base } \\
\text { catalyzed transesterification of } \\
\text { neutral oils }\end{array}$ & $\begin{array}{l}\text { Automated continuous } \\
\text { transesterification and } \\
\text { esterification, with pre- } \\
\text { esterification module for yellow } \\
\text { grease. On-the-fly adjustments of } \\
\text { variable feedstock. }\end{array}$ \\
\hline Status & $\begin{array}{l}10 \text { gph pilot plant, } 10 \text { mgy plant in } \\
\text { design, partnership with Dupps for } \\
\text { manufacture and assembly }\end{array}$ & $\begin{array}{l}1.0 \text { million liter/yr pilot operating } \\
\text { from } 2001.16 \mathrm{mgy} \text { plant in planned } \\
\text { for late } 2004 .\end{array}$ & Commercial & Fully commercial \\
\hline Feedstock & $\begin{array}{l}\text { Vegetable oils, animal fats, and } \\
\text { recycled fats and oils, up to } 100 \% \\
\text { FFA }\end{array}$ & $\begin{array}{l}\text { Any feedstock up to } 30 \% \text { FFA, } \\
\text { MIU }<2 \% \text {. }\end{array}$ & Variable & $\begin{array}{l}\text { Vegetable oils, greases, and animal } \\
\text { fats. Up to } 100 \% \text { FFA, MIU }<3 \% \text {, } \\
0.5 \% \text { H20, } 0.5 \% \text { Impurities, } 2 \% \\
\text { unsaponified materials. }\end{array}$ \\
\hline Pretreatment & $\begin{array}{l}\text { Only required if MIU exceeds } 3 \% \text {. } \\
\text { Requires a feedstock } \\
\text { preconditioning package }\end{array}$ & None & Variable & Depends on feedstock quality \\
\hline Processing costs & $\begin{array}{l}\$ 0.35 \text { to } \$ 0.50 \text { per gallon } \\
\text { depending on volume, utility costs, } \\
\text { labor costs, equip. depreciation, and } \\
\text { consumable price index }\end{array}$ & No information & Variable & $\begin{array}{l}\$ 0.42 \text { to } \$ 0.92 / \text { gal depending on } \\
\text { volume, utility, labor, equip deprec. } \\
\text { And consumable price index. } \\
\text { Includes } 5 \text { to } 24 \text { cent/gal deprec. }\end{array}$ \\
\hline Capacity & Up to $10 \mathrm{mgy}$ & $\begin{array}{l}\text { Minimum size is } 5 \text { mgy up to } 50 \\
\text { mgy }\end{array}$ & $\begin{array}{l}\text { Minimum size is } 5 \text { to } 10 \mathrm{mgy} \text {, no } \\
\text { upper limit }\end{array}$ & 3 mgy to 75 mgy \\
\hline Capital costs & $\begin{array}{l}\text { Ranges from } \$ 1.50 / \text { gal for } 4 \mathrm{mgy}, \\
\text { to } \$ 0.65 / \text { gal for } 30 \mathrm{mgy} \text {, includes } \\
\text { glycerin refining units }\end{array}$ & $\begin{array}{l}2 \text { to } 5 \mathrm{mgy}: \$ 1.25 / \mathrm{gal} \\
6 \text { to } 10 \mathrm{mgy}, \$ 1.00 \\
10 \mathrm{mgy}+, \$ 0.75 / \mathrm{gal}\end{array}$ & Variable & $\begin{array}{l}\text { Depends on FFA content and cost } \\
\text { of infrastructure }\end{array}$ \\
\hline Lead time & $\begin{array}{l}14 \text { months from permitting to } \\
\text { commissioning }\end{array}$ & Six months & Variable & $\begin{array}{l}11 \text { months after contract signed to } \\
\text { including commissioning }\end{array}$ \\
\hline Products & $\begin{array}{l}\text { ASTM, EN, DIN biodiesel, } \\
\text { glycerin from } 95 \% \text { to } 99.7 \% \text {, plus } \\
\text { fertilizer }\end{array}$ & $\begin{array}{l}\text { ASTM, DIN, EN biodiesel, 99\% } \\
\text { glycerin, salts }\end{array}$ & $\begin{array}{l}\text { ASTM biodiesel, } 99.7 \% \text { glycerin, } \\
\text { fatty acids }\end{array}$ & $\begin{array}{l}\text { ASTM, EN Biodiesel, } 80 \% \\
\text { glycerin, fertilizer }\end{array}$ \\
\hline Yield & $\begin{array}{l}\text { Depending on feedstock quality: } \\
7.5 \mathrm{lb} / \text { gal ester for vegetable oil } \\
8.25 \mathrm{lb} / \text { gal brown grease }\end{array}$ & 7.3 lb feedstock: 1 gallon B100 & $100 \%$ & $100 \%$ \\
\hline Warranties & $\begin{array}{l}\text { Process warranties include } \\
\text { feedstock yield, product quality and } \\
\text { plant throughput. Equipment and } \\
\text { installation warranties available. }\end{array}$ & $\begin{array}{l}\text { BIOX does not intent to sell or } \\
\text { license plants, End user ownership. } \\
\text { End user pays } \$ 0.50 / \text { gal fee to } \\
\text { BIOX. }\end{array}$ & $\begin{array}{l}\text { Warranties provided on capacity, } \\
\text { utility, and chemical consumption }\end{array}$ & $\begin{array}{l}12 \text { month warranty, maintenance } \\
\text { contract optional }\end{array}$ \\
\hline
\end{tabular}


Table 22. Commercial and Precommercial Biodiesel Technologies Available, 2004

\begin{tabular}{|c|c|c|c|c|}
\hline & Imperial Western Products, Inc. & Lurgi PSI, Inc. & Pacific Biodiesel, Inc. & Superior Process Technologies \\
\hline Contact & $\begin{array}{l}\text { Curtis Wright, P.E. } \\
86600 \text { Avenue } 54 \\
\text { Coachella, CA } 92236 \\
\text { 760-398-0815 } \\
\text { cwright@imperialwesternproducts.com }\end{array}$ & $\begin{array}{l}\text { Martin Kleber } \\
1790 \text { Kirby Pkwy, Suite } 300 \\
\text { Memphis, TN } 38138 \\
\text { 901-255-6434 } \\
\text { mkleber@lurgipsi.com }\end{array}$ & $\begin{array}{l}\text { Robert King } \\
\text { 285 Hukilike Street, B105 } \\
\text { Kahului, HA } 96732 \\
808-877-3144 \\
\text { bking@,biodiesel.com }\end{array}$ & $\begin{array}{l}\text { Tim Maneely } \\
\text { 2136 Ford Pkwy, \# } 262 \\
\text { St. Paul, MN 55116 } \\
\text { 651-699-0758 } \\
\text { tmaneely@superiorprocesstec.com }\end{array}$ \\
\hline Technology & Batch plant & $\begin{array}{l}\text { Continuous transesterification } \\
\text { using patented reactors and } \\
\text { glycerin systems }\end{array}$ & $\begin{array}{l}\text { Batch process in } 400,000 \text { gy } \\
\text { increments }\end{array}$ & $\begin{array}{l}\text { Continuous process for all } \\
\text { feedstocks, batch plants available } \\
\text { for small producers, biodiesel } \\
\text { distillation available }\end{array}$ \\
\hline Status & Commercial & Commercial since1988 & Commercial & Engineering \\
\hline Feedstock & $\begin{array}{l}\text { Oils or yellow grease, up to } 40 \% \text { FFA, } \\
\text { MIU }<2 \%\end{array}$ & $\begin{array}{l}\text { FFA up to } 20 \% \text { (probably all } \\
\text { feedstocks) }\end{array}$ & Up to $6 \%$ (probably all feedstocks) & $\begin{array}{l}\text { Up to } 30 \% \text { FFA (probably all } \\
\text { feedstocks), MIU }<2 \%\end{array}$ \\
\hline Pretreatment & Filter and $\mathrm{H} 20$ reduction & Yes & None & Depends on feedstock \\
\hline Processing costs & $\begin{array}{l}40 \text { to } 80 \text { cents/gal depending on } \\
\text { volume }\end{array}$ & $\begin{array}{l}13.7 \text { cents per gallon at } 30 \mathrm{mgy} \\
\text { including glycerin coproduct of } \\
\$ 0.225 \text { per gallon B100 }\end{array}$ & Proprietary & Depends on plant capacity \\
\hline Capacity & Up to $10 \mathrm{mgy}$ & $0.75 \mathrm{mgy}$ up to $35 \mathrm{mgy}$. & $0.2 \mathrm{mgy}$ to $2.0 \mathrm{mgy}$ & $\begin{array}{l}\text { Continuous down to } 3 \text { mgy with no } \\
\text { upper limit. Smaller plants will be } \\
\text { batch. Skid mounted available up to } \\
5 \mathrm{mgy}\end{array}$ \\
\hline Capital costs & $\$ 0.20$ to $\$ 0.50$ per gallon & $\begin{array}{l}2 \text { to } 6 \text { mgy: } \$ 1.00 \text { per gallon } \mathrm{B} 100 \\
6 \text { to } 10 \text { mgy: } \$ 0.63 \text { per gal } \mathrm{B} 100 \\
10 \mathrm{mgy}+, \$ 0.26 \text { per gallon } \mathrm{B} 100\end{array}$ & $\$ 1.00$ per gallon & $\begin{array}{l}2 \text { to } 6 \text { mgy: } \$ 1.00 \text { to } \$ 2.50 \text { per gal } \\
6 \text { to } 10 \text { mgy: } \$ 0.75 \text { to } \$ 1.70 \text { per gal } \\
10 \text { mgy }+, \$ 0.50 \text { to } \$ 1.30 \text { per gal }\end{array}$ \\
\hline Lead time & One year & $\begin{array}{l}\text { Eight months for } 2.5 \mathrm{mgy} \\
13 \text { months for } 10 \mathrm{mgy}\end{array}$ & Six months & 6 to 14 months from permitting \\
\hline Products & ASTM Biodiesel, 90\% glycerin & $\begin{array}{l}\text { ASTM, DIN, EN Biodiesel, 99.8\% } \\
\text { biodiesel }\end{array}$ & $\begin{array}{l}\text { ASTM, DIN Biodiesel, 50\% } \\
\text { glycerin }\end{array}$ & $\begin{array}{l}\text { ASTM, DIN Biodiesel, } 80 \% \text { to } \\
99.7 \% \text { glycerin, fertilizer }\end{array}$ \\
\hline Yield & $98 \%+$ & $\begin{array}{l}\text { RDB oil } 100 \% \text {, other feedstocks } \\
\text { depends }\end{array}$ & 10 lb oil: one gallon B100 & Depends on feedstock \\
\hline Warranties & Performance warranty & $\begin{array}{l}\text { Warranties biodiesel and glycerin } \\
\text { quality, capacity, chemical and } \\
\text { energy consumption, time } \\
\text { schedules }\end{array}$ & $\begin{array}{l}\text { Equipment warranty on plant for } \\
\text { one year; tanks and piping for five } \\
\text { years. }\end{array}$ & $\begin{array}{l}\text { Process and equipment warranties, } \\
\text { specific to customer requirements }\end{array}$ \\
\hline
\end{tabular}




\subsection{Biodiesel Production Costs}

Biodiesel production suffers from high feedstock costs. Biodiesel conversion costs less.

Feedstock costs are roughly the same regardless of feedstock quality or processing technology.

Table 23. Biodiesel Production Costs by Feedstock and Process Technology

\begin{tabular}{|c|c|c|c|c|c|}
\hline $\begin{array}{l}\text { Cost Category } \\
\text { \$/gal ester }\end{array}$ & $\begin{array}{c}\text { Virgin } \\
\text { Oil } \\
\text { Bottoms } \\
\text { Recovery }\end{array}$ & $\begin{array}{c}\text { Virgin } \\
\text { Oil } \\
\\
\text { No } \\
\text { Bottoms }\end{array}$ & $\begin{array}{c}\text { "Low" } \\
\text { FFA } \\
\text { Grease } \\
\text { Bottoms } \\
\text { Recovery }\end{array}$ & $\begin{array}{c}\text { "High" } \\
\text { FFA } \\
\text { Grease } \\
\text { Bottoms } \\
\text { Recovery }\end{array}$ & $\begin{array}{c}\text { Trap } \\
\text { Grease } \\
\text { Bottoms } \\
\text { Recovery }\end{array}$ \\
\hline FFA content & $0.1 \%$ & $0.1 \%$ & $2.0 \%$ & $50 \%$ & $75 \%$ \\
\hline Capital Cost, \$ Million & 11.364 & 7.233 & 12,493 & 13,659 & 13,659 \\
\hline Feed oil & 1.539 & 1.539 & 0.961 & 0.497 & 0.058 \\
\hline Other reagents & 0.199 & 0.251 & 0.147 & 0.167 & 0.167 \\
\hline Subtotal inputs & 1.738 & 1.79 & 1.108 & 0.663 & 0.225 \\
\hline Personnel & 0.035 & 0.035 & 0.04 & 0.04 & 0.04 \\
\hline Utilities (heater fuel, electrical, water) & 0.034 & 0.024 & 0.044 & 0.046 & 0.046 \\
\hline Maintenance (material, personnel, services) & 0.031 & 0.022 & 0.034 & 0.037 & 0.037 \\
\hline Insurance $\&$ taxes ( $2 \%$ of capital) & 0.015 & 0.01 & 0.017 & 0.018 & 0.018 \\
\hline Packaging, shipping supplies & 0.001 & 0.001 & 0.001 & 0.001 & 0.001 \\
\hline Legal, accounting, supplies & 0.006 & 0.006 & 0.006 & 0.006 & 0.006 \\
\hline Contingency & 0.022 & 0.022 & 0.022 & 0.022 & 0.022 \\
\hline Plant level operating costs & 1.883 & 1.91 & 1.271 & 0.834 & 0.395 \\
\hline Management/admin/support services & 0.011 & 0.011 & 0.011 & 0.011 & 0.011 \\
\hline Total operating costs (including feed oil) & 1.894 & 1.921 & 1.283 & 0.845 & 0.406 \\
\hline Biodiesel conversion costs (op cost-feedstock) & 0.356 & 0.383 & 0.321 & 0.348 & 0.348 \\
\hline Total operating costs include feed oil & 1.894 & 1.921 & 1.283 & 0.845 & 0.406 \\
\hline Interest on working capital (9\%) & 0.021 & 0.022 & 0.014 & 0.01 & 0.005 \\
\hline Depreciation (10 year) & 0.076 & 0.048 & 0.083 & 0.091 & 0.091 \\
\hline Total production costs & 1.991 & 1.991 & 1.38 & 0.946 & 0.502 \\
\hline Total production costs less feed oil & 0.453 & 0.453 & 0.419 & 0.449 & 0.444 \\
\hline Fatty acid coproduct credits & -0.032 & 0 & -0.017 & -0.016 & 0 \\
\hline Glycerin credit & -0.054 & -0.047 & -0.053 & -0.017 & -0.017 \\
\hline Total credits & -0.086 & -0.047 & -0.07 & -0.033 & -0.017 \\
\hline Net production costs with feedstock & 1.905 & 1.944 & 1.311 & 0.912 & 0.485 \\
\hline Net production Costs less Feedstock & 0.366 & 0.405 & 0.35 & 0.416 & 0.427 \\
\hline Fuel grade methyl esters produced (MM gal) & 15 & 15 & 15 & 15 & 15 \\
\hline Glycerin (100\% glycerol basis) (MM lbs) & 10.107 & 10.107 & 9.915 & 5.059 & 5.059 \\
\hline Fatty acid/ester byproducts (MM lbs) & 9.65 & 9.65 & 8.355 & 12.336 & 12.336 \\
\hline
\end{tabular}


Modest cost reductions can be realized through economies of scale, which reduce capital cost per gallon capacity and labor costs per gallon of throughput. At 50 million gallons per year or more, total non-feedstock production costs will only be 5 to 7 cents per gallon of B100, lower than the examples shown in Table 23. There are systems that use fixed catalysts, which reduce variable costs but raise fixed costs. Some systems are catalyst free, which might save as much as 19 cents per gallon in processing costs, but raise capital and energy costs because these systems tend to be high pressure and temperature systems. Even if nonfeedstock costs could be cut in half, the savings are not enough to make biodiesel competitive with diesel fuel, since most biomass oil feedstocks cost more than diesel fuel to begin with.

Table 24. Capital Cost Varies by Scale ${ }^{45}$

\begin{tabular}{|c|c|c|}
\hline $\begin{array}{l}\text { Plant size } \\
\text { Million gallons per year }\end{array}$ & $\begin{array}{l}\text { Low } \\
\text { MM\$ }\end{array}$ & $\begin{array}{l}\text { High } \\
\text { MM\$ }\end{array}$ \\
\hline \hline 1.0 & 1.9 & 3.1 \\
\hline 15.0 & 9.5 & 15.8 \\
\hline 50.0 & 19.7 & 32.8 \\
\hline
\end{tabular}

Continuous systems exist for all feedstocks. Since yields are uniformly high across most commercial technologies $(98 \%+)$ there is little opportunity to improve biodiesel conversion technology in a manner that will reduce total production costs by more than a few cents per gallon.

An examination of the glycerin refining system within a biodiesel plant reveals equally difficult trade offs. Crude biodiesel glycerin is roughly 50\% glycerol, plus water, methanol, unreacted and partially reacted fats, esters, free fatty acids, and neutralized catalyst salts. Most firms refine the glycerin to $80 \%$ or $88 \%$ purity with some type of vacuum distillation to reduce transportation costs associated with water. Low temperatures are critical to avoid discoloring and polymerizing the glycerol. Methanol is recovered, and in most cases, a significant fraction of the fatty acid compounds are recovered. The key problem with biodiesel glycerin is the salt content and impurities that are introduced by using recycled feedstocks.

There are a variety of salt-removing technologies developed for the potable water industry using membranes, ion exchange and other technologies (compared to vacuum distillation). There may be an opportunity to develop less expensive glycerol refining technologies for biodiesel firms. Some research has been conducted in this area, but funding has not been available for a more detailed examination of how these technologies may provide a benefit to biodiesel producers.

At this time, using mature glycerin refining technologies, biodiesel plants must provide at least 10 million gallons per year and preferably in the 20 to 30 million gallon per year range to support glycerin refining technology. Until U.S. demand for biodiesel can support large plants, it is still too risky to build them. As the industry grows, regional glycerol toll refiners may expand to

\footnotetext{
${ }^{45}$ Independent Business Feasibility Group, LLC. November 1998. The Biodiesel Plant Development Handbook. Kearney, MO.
} 
accommodate biodiesel glycerin until biodiesel demand grows large enough to support larger facilities with internal glycerol refining capacity.

P\&G estimated that refining costs to produce United States Pharmacopeia (USP) quality glycerol were less than 20 cents per pound using vegetable oil glycerin. ${ }^{46}$ Other grades of glycerol are discounted against USP prices. USP glycerol market prices have been dropping from $\$ 1.00$ per pound to roughly $\$ 0.50$ per pound as the European biodiesel market expanded in the 1990s. Assuming 50 cent a pound value for USP glycerol and 20 cents per pound refining costs, the net credit to the biodiesel plant is 30 cents per pound. One gallon of biodiesel produces 0.735 pounds of glycerol theoretically (with yield losses the number is less). The maximum credit is 22 cents per gallon for large-scale biodiesel plants with glycerol refining capacity.

Glycerol produced from dark fats and greases has a higher level of color and odor contaminants as well as other minor compounds. Refining costs for this type of glycerin are higher and the sale value is lower because markets are restricted to technical uses rather than food or pharmaceutical uses.

Novel biodiesel production technology may improve the quality and value of the crude glycerin produced by biodiesel plants. The least desirable contaminant in crude glycerin is the spent salts from the esterification reactions. These can represent $10 \%$ to $30 \%$ of the crude glycerin by weight depending on the feedstock and process. Fixed catalyst systems, fluidized bed, packed beds, molecular sieves, etc., could eliminate spent catalysts in the glycerin leaving it relatively easy to refine into glycerol, even for small scale plants. There are some fixed acid, resin acid catalysts used for acid esterification and widely used in the petroleum industry but their conversion efficiency is not high enough for biodiesel production. Development, testing and optimization of fixed base and acid-base catalysts would improve the quality and value of the glycerin produced. This in turn, could enable small biodiesel producers to make coproducts from the glycerol, refine it relatively inexpensively, and provide an avenue towards product diversification.

\subsection{Bio-distillate Production}

In the late 1970's Mobile researchers showed that a variety of biomass substrates could be catalytically converted to liquid aromatic hydrocarbons and olefins using a shape selective ZSM5 zeolite catalyst. One of the feedstocks tried was corn oil. The hydrocarbon end products represented clean premium fuels: LPG, high octane gasoline with a high aromatic content, and a light distillate fraction.

Recent studies in Brazil showed that different fuels and industrial chemicals can be produced from vegetable oils, frequently in the high yields, simply by changing the nature of the catalyst, temperature and reaction period. ${ }^{47}$ With no catalyst and a thermal cracking temperature of

\footnotetext{
${ }^{46}$ All materials listed in the USP are considered drugs by law and subject to all the U.S. Food \& Drug Administration requirements pertaining to drugs. Labeling a product or a substance as USP implies that it conforms to all the legal requirements of the FDA and that it was produced in accordance with the principles outlined in FDA's Good Manufacturing Practices (GMP). A new edition of the USP is published every five years in the years ending in "0" and "5," with ongoing revisions and additions issued during the interim years.

${ }^{47}$ Alencar et al. 1983. Journal of Agricultural Food Chemistry, V31. No. 6, (pp. 1268-70).
} 
$350^{\circ} \mathrm{C}$, the main products were terminal olefins and n-alkanes derived from free radical disproportionation and decarboxylation of the vegetable oil. ${ }^{48}$ With calcium oxide as a catalyst, the main products were long chain methyl ketones. Bentonite catalysts gave alkylbenzenes some what analogous to the shape selective zeolite catalysts.

Research at the University of Saskatchewan has shown that canola oil and tall oil can be converted with yields in excess of $98 \%$ by weight using the Mobile catalysts to a mixture of $70 \%$ - 75\% high octane gasoline and other hydrocarbons using fluid catalytic cracking (FCC).

Subsequent work funded by the Natural Resources Canada was conducted by the Saskatchewan Research Council to convert a wide range of plant oils into diesel cetane improvers. ${ }^{49}$ The process involved a medium severity hydroprocess operating in laboratory-scale conventional refinery hardware under proprietary temperatures and pressures. Several reactions occurred in the process including hydrocracking (breaking apart the triglycerides, otherwise known as splitting), hydrotreating (removing the oxygen, or otherwise known as decarboxylation) and hydrogenation (saturating the double bonds). The hydroprocessing catalysts employed were conventional hydrotreating catalysts including cobalt-molybdenum (Co-Mo), nickel molybdenum (Ni-Mo) and other transition metal catalysts such as American Cynamid HDS-20 or Shell S-424. Hydroprocessing conditions ranged from $350^{\circ} \mathrm{C}$ to $450^{\circ} \mathrm{C}$ and a pressure from 4.8 Mpa to about $15.2 \mathrm{Mpa}$ and a liquid hourly space velocity of 0.5 to 5.0 per hour, depending on feedstock. Experiments were conducted with canola, sunflower, palm, soy, high erucic rapeseed oils and the fatty acid fraction of tall oil. The grade of oil appeared to affect processing conditions. More refined oils produced good yields at the lower end of the temperature and pressure ranges while the unrefined or lower quality oils required higher temperatures and pressures to achieve good results. "Diesel" yields of $80 \%$ of total feedstock routinely observed under optimized conditions. ${ }^{50}$ No unusual byproducts were produced and all products other than the diesel fraction were suitable for further processing with other conventional refinery streams.

In all likelihood, the process produced fully hydrogenated straight chain paraffins similar to oleochemical detergent processes, with the primary different occurring in the splitting step. The high cetane and cloud points $\left(20^{\circ} \mathrm{C}\right)$ of the resulting diesel fractions used as cetane improvers support this assumption as do the patent claims "Surprisingly, the hydroprocessing conditions ...work very efficiently to convert the triglycerides feedstock to paraffinic hydrocarbon chains corresponding in length to the original "branches" in the basic triglycerides structure" (meaning the fatty acid chains). When canola oil was processed at $370^{\circ} \mathrm{C}$ and $4.8 \mathrm{MPa}$, the GC-MS analysis of the $210^{\circ} \mathrm{C}$ to $343^{\circ} \mathrm{C}$ fraction contained $95 \%$ straight chain alkanes with 15 to 18 carbons. The fatty acid composition of the oil affected the fraction of product that resulted in the $210^{\circ} \mathrm{C}$ to $343^{\circ} \mathrm{C}$ temperature range.

Processing was done on biomass oils and biomass oils combined with light cycle petroleum oil.

\footnotetext{
${ }^{48}$ Decarboxylation is a common oleochemical technology used to produce detergent compounds.

${ }^{49}$ Stumborg et al. 1996. BioSource Technology 56 (pp. 13-18) and UNITED STATES Patent 4992605.

${ }^{50}$ Long chain (16-18) saturated hydrocarbons that boil in the same range as diesel fuel and possess other characteristics similar to diesel.
} 
The Adept Group has marketed this product in the United States under the trade name "Agtane." A1 As a pure compound or mixture of compounds the product does not meet ASTM D 975 for diesel fuel, but blends of this compound with diesel fuel No. 2 produce acceptable fuels with high cetane numbers.

Marc Pontioff, of Carnegie Mellon has also made several patent applications that cover the conversion of biomass oils into typical refinery products using a combination of conventional and novel technologies. ${ }^{52}$ As these applications are pending, details will not be provided here.

From the work above, it is clear that biomass oils has the potential to be processed in existing petroleum refining infrastructure, with some modifications and adjustments, either alone or in combination with petroleum fuels. These processes will require further modifications, optimization, and demonstration on a commercial scale. It is not clear what form the products will be commercialized in at this time, as neat fuels or as components of conventional refinery products or both.

A production cost estimate was provided by Adept Group (op cite) (Table X). Assuming yellow grease feedstocks at 8 cents per pound, Agtane could be produced for $\$ 1.35$ per gallon including capital charges, royalties, etc. One gallon of Agtane requires 1.3 gallons of yellow grease feedstock. It is not clear if the cost estimate represent the use of existing infrastructure or a new stand-alone production facility, but the capital charges shown appear to be in line with a new plant construction.

Table 25. Agtane production costs

\begin{tabular}{|l|c|}
\hline Outlays & $\begin{array}{l}\text { \$ Per Gallon } \\
\text { of Agtane }\end{array}$ \\
\hline Yellow grease & 0.78 \\
\hline Storage & 0.01 \\
\hline Hydrogen & 0.18 \\
\hline Heat (steam) & 0.04 \\
\hline Operating costs & 0.10 \\
\hline Capital charges & 0.15 \\
\hline Overhead charges & 0.03 \\
\hline Rolyalties to CANMET & 0.06 \\
\hline Total & 1.35 \\
\hline
\end{tabular}

Distributing Agtane as an additive involves significant distribution and marketing charges and implies that the product sold is offered at a price more in line with other additives rather than as a fuel component.

If a product similar to Agtane is produced at an existing refinery, using existing steam and hydroprocessing infrastructure, and the product is either commingled or blended into other

\footnotetext{
${ }^{51}$ Spataru, Alex. February 2001. “Is there a Future for Yellow Grease as a Fuel Additive?” Render Magazine, pp. 12-14.

${ }^{52}$ Email and personal discussions dating from January 2003 through December 2003.
} 
petroleum fuels and marketed through existing fuel infrastructure, then the resulting cost can be expected to be less than that proposed for Agtane and more in line with other refinery costs.

A key savings will be created by distributing the product commingled with other petroleum products, which avoids the typically costly storage, transportation and blending of most renewable fuel components such as ethanol or biodiesel. 


\section{BIOREFINERY OPPORTUNTIES}

There are several areas for biorefinery opportunities.

1. At the crushing mill

2. At the biodiesel plant (oleochemical production)

3. Combining 1 and 2 above.

Crushers produce meal, hulls, oil, and some minor byproducts such as Vitamin E, sterols, and lethicin. There are a large and growing number of potential protein extracts that are being produced from the meal that provide new and expanding markets and offer high value as food products. These can add new products and revenue to crushing biorefineries. Increasing demand for these products may raise the value of meal, raise the demand for meal, and lead to more soybean crushing and oil production.

Most methyl ester plants that produce oleochemicals are already biorefineries. Methyl esters are one of two primary intermediate chemical systems that produce literally thousands of chemical derivatives for nearly every industry in the United States. While new oleochemical technologies are constantly emerging, maximizing the number and value of products from oleochemical plants is a well understood strategy in the oleochemical industry. Communicating these opportunities to emerging biodiesel producers and crushers can generate higher rates of return for these newcomers.

The level of integration between the crushing or rendering industry and the oleochemical industry is nil. Most oleochemical firms purchase fat and oil feedstocks. Only one North American renderer produces oleochemicals (Rothsay in Canada). ADM and Cargill are beginning to develop value added products from their oils, but this strategy is relatively new to the industry and is not wide spread.

The key place where biorefinery technology may benefit the biomass oil industry is in the crushing and rendering mills. If the low value animal feed components (priced at 8 to 12 cents per pound) can be sold for a higher value, expanded crushing activity could increase the amount of oil produced, and over time, reduce the market price of that oil if new markets for that oil cannot keep pace.

\subsection{Crushing Biorefineries}

From our previous discussion we noted that crushers produce oil and protein meal. Not only is the protein fraction of meal important with respect to its market price (Table 26) but the types of proteins, the various minor compounds, and other attributes affect its value as an animal feed, an extract for the food market, and a chemical substrate (Table 27 and Table 28).

A soybean contains protein, amino acids, saponins, phytic acid, trypsin inhibitors, fiber, isoflavones, polyunsaturated oils, minerals, vitamins, and carbohydrates (Table 27 and Table 28). The most common isoflavones (also referred to as phytoestrogens) are genistein, daidzein and glycitein. The isoflavone molecule resembles estradiol, an estrogen compound in humans. 
Isoflavone has properties similar to the antiestrogen tamoxifen and has shown to relieve some menopause symptoms. The pharmaceutical and health food industry is interested in soy for its balanced protein and amino acid content and its potential health benefits on cancers (breast, endometrial, prostate, lung, thyroid, colon) and osteoporosis. The polyunsaturated fatty acid provides cardiovascular and cholesterol benefits. ${ }^{53}$ Soy products for human consumption have been growing rapidly in the United States.

Table 26. Comparative Composition of Various Oilseed Meals

\begin{tabular}{|l|l|l|l||}
\hline & $\begin{array}{l}\text { Crude Protein Extract } \\
\%\end{array}$ & $\begin{array}{l}\text { Fiber } \\
\%\end{array}$ & $\begin{array}{l}\text { Energy } \\
\text { kcal/kg }\end{array}$ \\
\hline Soybean meal & 44.0 & 0.5 & 2240 \\
\hline Dehulled soybean meal & 48.5 & 1.0 & 2475 \\
\hline Canola meal & 38.0 & 3.8 & 2110 \\
\hline Cottonseed meal & 41.0 & 0.8 & 1940 \\
\hline Linseed meal & 33.0 & 0.5 & 1400 \\
\hline Peanut meal & 48.0 & 1.5 & 2200 \\
\hline Rapeseed meal & 36.0 & 2.6 & 1770 \\
\hline Safflower meal & 42.0 & 1.3 & 2040 \\
\hline Sesame meal & 42.0 & 7.0 & 2255 \\
\hline Sunflower meal & 42.0 & 2.3 & 1760 \\
\hline \hline
\end{tabular}

Table 27. Amino Acid Content of Soybeans ${ }^{54}$

\begin{tabular}{|c|c|}
\hline Amino Acids & $\begin{array}{l}\text { Soybean } \\
\mathrm{g} / 16 \mathrm{~g} \mathrm{~N}\end{array}$ \\
\hline \hline Isoleucine & 5.1 \\
\hline \hline Leucine & 7.7 \\
\hline \hline Lysine & 6.9 \\
\hline Methionine & 1.6 \\
\hline Cystine & 1.3 \\
\hline Phenylalanine & 5.0 \\
\hline Threonine & 4.3 \\
\hline Tryptophane & 1.3 \\
\hline \hline Valine & 5.4 \\
\hline \hline Histidine & 2.6 \\
\hline \hline
\end{tabular}

53 Colebank, S. (2002, April). Deconstructing Soy. HSR Health Supplement Retailer. p.16-21.

${ }^{54}$ Wijeratne, Wilmont B. Composition of Soybean. University of Illinois. http://www.mojib.com/hb2.htm 
Table 28. Nutrient Composition of Soybean Products

\begin{tabular}{|c|c|c|c|c|}
\hline \&NBSP & \begin{tabular}{|l|} 
Soybean \\
Full-fat
\end{tabular} & \begin{tabular}{|l|}
$\begin{array}{l}\text { Soybean Meal } \\
\text { Expeller }\end{array}$ \\
\end{tabular} & Solvent & Dehulled \\
\hline Intl. feed number & $5-04-597$ & $5-04-600$ & $5-04-604$ & $5-04-612$ \\
\hline Dry matter \% & 90.0 & 89.0 & 90.0 & 89.0 \\
\hline Crude protein \% & 38.0 & 42.0 & 44.0 & 48.5 \\
\hline Ether extract \% & 18.0 & 3.5 & 0.5 & 1.0 \\
\hline Crude fiber \% & 5.0 & 6.5 & 7.0 & 3.0 \\
\hline Ash \% & 4.6 & 6.0 & 6.0 & 6.0 \\
\hline Ruminant dig protein $\%$ & 34.1 & 35.5 & 37.5 & 46.6 \\
\hline Ruminant TDN \% & 85.0 & 78.0 & 78.0 & 79.0 \\
\hline Poultry ME kcal/kg & 3350. & 2420. & 2240. & 2475. \\
\hline Swine ME kcal/kg & 3540. & 2990. & 3090. & 3140. \\
\hline Methionine \% & 0.54 & 0.6 & 0.65 & 0.75 \\
\hline Cystine \% & 0.55 & 0.62 & 0.67 & 0.74 \\
\hline Lysine \% & 2.4 & 2.7 & 2.9 & 3.2 \\
\hline Tryptophan \% & 0.52 & 0.58 & 0.6 & 0.7 \\
\hline Threonine $\%$ & 1.69 & 1.7 & 1.7 & 2.0 \\
\hline Isoleucine $\%$ & 2.18 & 2.8 & 2.5 & 2.6 \\
\hline Histidine $\%$ & 1.01 & 1.1 & 1.1 & 1.3 \\
\hline Valine $\%$ & 2.02 & 2.2 & 2.4 & 2.7 \\
\hline Leucine \% & 2.8 & 3.8 & 3.4 & 3.8 \\
\hline Arginine \% & 2.8 & 3.2 & 3.4 & 3.8 \\
\hline Phenylalanine $\%$ & 2.1 & 2.1 & 2.2 & 2.7 \\
\hline Vitamin E mg/kg & 31. & 6.6 & 3. & 3.3 \\
\hline Thiamine $\mathrm{mg} / \mathrm{kg}$ & 6.6 & 1.7 & 1.7 & 1.7 \\
\hline Riboflavin $\mathrm{mg} / \mathrm{kg}$ & 2.64 & 4.4 & 3.0 & 2.6 \\
\hline Pantothenic acid mg/kg & 15.62 & 13.8 & 13.3 & 13.2 \\
\hline Biotin ug $/ \mathrm{kg}$ & 286. & 320. & 320. & 320. \\
\hline Folic acid ug/kg & 3520. & 450. & 450. & 700. \\
\hline Choline $\mathrm{mg} / \mathrm{kg}$ & 2420. & 2673. & 2743. & 2850. \\
\hline Niacin $\mathrm{mg} / \mathrm{kg}$ & 22.0 & 36.7 & 59.8 & 20.9 \\
\hline Calcium \% & 0.2 & 0.25 & 0.25 & 0.2 \\
\hline Phosphorus \% & 0.6 & 0.6 & 0.6 & 0.65 \\
\hline Sodium \% & 0.04 & 0.04 & 0.04 & 0.04 \\
\hline Potassium \% & 1.7 & 1.71 & 1.97 & 1.9 \\
\hline Chloride \% & 0.03 & 0.02 & 0.02 & 0.02 \\
\hline Magnesium \% & 0.21 & 0.25 & 0.27 & 0.27 \\
\hline Sulphur \% & 0.30 & 0.33 & 0.43 & 0.43 \\
\hline Manganese ppm & 30. & 32.3 & 27.5 & 27.5 \\
\hline Iron ppm & 75. & 160. & 120. & 120. \\
\hline Copper ppm & 15. & 18. & 28. & 28. \\
\hline Zinc ppm & 35. & 59. & 60. & 60. \\
\hline Selenium ppm & 0.1 & 0.1 & 0.1 & 0.1 \\
\hline
\end{tabular}




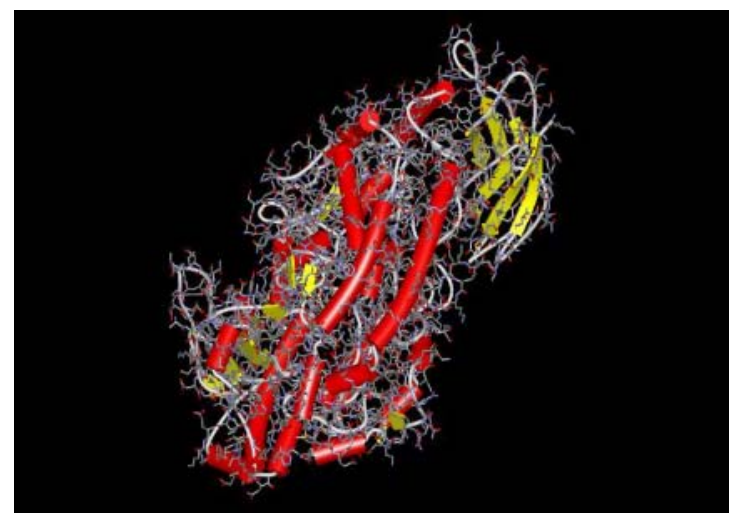

Figure 24. Typical Soy Protein, Battelle Memorial Institute

In the 10th Annual "Consumer Attitudes about Nutrition" study, ${ }^{55} 38 \%$ of those surveyed knew that consuming 25 grams of soy protein a day can help reduce the risk of coronary heart disease. Many consumers viewed a diet including soy products as a way to help fight obesity and encourage weight loss. The soybean checkoff-funded survey also reported that many of the women surveyed sought out soy products as a natural, healthy and safe alternative to hormone replacement therapy, which has been found to increase the risk of breast cancer, heart disease, stroke and pulmonary embolism. The survey also found that many more consumers use soy products on a regular and trial basis. Soymilk, which increased in regular usage from $14 \%$ in 2002 to $17 \%$ in 2003 , showed the largest consumption gain among soy foods. The number of consumers who tried the product also increased from 35 percent in 2002 to $39 \%$ in 2003. Soy burgers, soy protein bars and whole green soybeans exhibited similar increases in regular and trial usage. A large number of studies are underway to isolate specific compounds and their therapeutic value on human health.

Because the margins on consumer products, pharmaceuticals, and health foods are generally higher than those for industrial products or platform chemicals, the growth market for soy meal and soy meal values will be in consumer product industries for the near future.

The soy industry is funding research to improve the animal feed value of soybean, including higher protein content, higher lysine content (up to a 3 fold increase) (Table 27), and more digestible sugars. The carbohydrates present in soybeans are shown in Table 29. Researchers are trying to shift the sugar content towards sucrose and away from raffinose to improve the available energy content of the feed for livestock that cannot digest raffinose and some of the other sugar compounds. This could make the carbohydrate fraction of soybeans more amendable to fermentation for ethanol production. Recent discussions with USDA and industry leaders have revealed that several firms are exploring the relatively untapped potential of developing novel products from protein isolates. Battelle has recently modeled soy protein in preparation for value-add processing studies. Some examples of products made from proteins include adhesives, films, fibers, and lotions that carry oil-bound proteins as delivery systems.

\footnotetext{
${ }^{55}$ Soyatech Blue Book, "More Consumers Enjoying Soy Than Ever, Check Off Finds", August 26, 2003. http://www.soyatech.com/bluebook/news/viewarticle.ldml?a=20030826-1
} 
Table 29. Carbohydrates in Soybeans ${ }^{56}$

\begin{tabular}{|l|c|}
\hline Constituents & $\begin{array}{c}\text { Average Amount } \\
\text { Percentage of Whole Soybeans }\end{array}$ \\
\hline Cellulose & 4.0 \\
\hline \hline Hemicellulose & 15.0 \\
\hline Stachyose & 3.8 \\
\hline Raffinose & 1.1 \\
\hline \hline Sucrose & 5.0 \\
\hline \hline Other sugars & 5.1 \\
\hline \hline & \\
\hline & \\
& \\
\hline
\end{tabular}

It appears that proteins may offer the next platform chemical for the oilseed industry. At the current price of $\$ 1 / \mathrm{lb}$, only high value markets such as food additives are feasible for isolates.

The lower priced soy concentrates ( 50 cents per pound) and even soy meal ( 8 to 12 cents per pound) can also be used as additives where the proteins impart some functionality. For example, some composite board material has been produced from soy meal. It appears that research focused on using meal as the platform substrate offers a promising avenue for value added products at this time.

Increasing the number and value of products from meal can lead to higher crushing rates and more byproduct oil production. If the entire international industry adopted these new products and crushing rises, the excess supplies of oil can drive down international oil prices. Similarly, increasing the production of palm oil can drive down the value of soy oil. Because soy oil prices, and to a lesser extent palm oil, set market prices for all fats and oils, major shifts in industrial patterns are required to change soy prices.

A slightly different variation on this theme was the mustard project, which attempted to increase the value of the meal by developing pesticide uses. The meal of mustard and industrial rape contains high levels of glucosinolates that are toxic to many living organisms including agricultural pests such as fungi, nematodes, cut worms, insects, and weed seeds. The meal value as an animal feed is low, in the 2 to 4 cents per pound range. By developing the mustard meal into an organic pesticide that organic farmers are willing to pay 10-15 cents a pound for, a new oil seed crop would be developed that would enhance oil supplies. The meal has to be defatted to maximize the effectiveness of the pesticide. The meal has to be certified as a legal pesticide by the EPA before it can be commercially produced for this market.

The Food and Drug Administration (FDA) has stated that they are not willing to provide an edible oil status to mustard oil pressed from high glucosinolate seeds, so the oil is inedible in the United States. ${ }^{57}$ As an inedible oil, its price will be limited to that of inedible tallow.

\footnotetext{
${ }^{56}$ Wijeratne, Wilmont B. Composition of Soybean. University of Illinois. http://www.mojib.com/hb3.htm

${ }^{57}$ Conversation with Jack Brown, University of Idaho, Spring 2003.
} 


\section{United Soybean Board Success Stories}

One of the most versatile products USB has helped develop is SoyOyl, a soy-based polyol used to manufacture rigid and flexible polyurethanes produced by Urethane Soy Systems Co., Princeston, IL. Currently, John Deere is using SoyOyl panels on combines and claims the product is cost competitive with petroleum based plastics. Ford's Model U uses SoyOyl for seat foam. Arm rests and door panels are other possible uses. The Model U's tailgate is made from a soy-based resin reinforced with fiberglass. Rhino is manufacturing a truck bed liner made from SoyOyl. SoyOyl is being used as carpet backing by one major manufacturer. Soy-based products can be recycled into organic material at the end of their useful lives.

Soy-based carpet backing, BIOBALANCETM polymers, is manufactured by Dow Chemical Company. The carpet backing is the thin layer that binds the carpet fibers together. Polyurethane-backed carpets are used in high-traffic and frequently cleaned areas because of their durability. BIOBALANCE incorporates soybean oil into its formulation by replacing a portion of the petrochemical-based backing system. Additional research is under way to evaluate the same technology for attached foam carpet padding.

A spray foam insulation made from soy-based polyurethane is available in three different formulations ranging in R-value from 13 to 24 . It provides excellent insulation qualities and is less expensive than traditional spray foam insulations. The insulation expands in the wall as traditional spray foam insulations do and does not contain formaldehyde. The soy insulation provides as good as or better insulation characteristics in 4-inch stud walls than traditional insulations do with 6-inch stud construction. Using the more energy efficient soy-based insulation can significantly reduce building costs by decreasing the amount of lumber used in framing the structure. In addition, the soy-based spray foam is not affected by time or moisture, will not settle and is completely resistant to mold and mildew.

Fiber Research International (FRI), Seattle, WA developed a cost-effective replacement for petroleumbased phenols for wood adhesive. Hydrolyzed soybean meal can be used existing resin manufacturing equipment. Six resin manufacturers, two that make panels, are working with FRI to commercial the soybased product.

Niemann Laboratories developed a soy oil-based applied roofing coating, Natural Bitumen Jacket, that provides relief from intense sunlight. Natural Bitumen Jacket is a bright white product that is applied over bituminous substrates and has a rapid cure time. By reducing the amount of energy absorbed from intense sunlight, air conditioning energy and costs are reduced. Natural Bitumen Jacket has an "Energy Star" approval.

Epoxidized soybean oil (ESO) is a commodity product with about 150 million pounds produced each year in the United States. It is made by reacting soybean oil with hydrogen peroxide and acetic acid. ESO is used primarily in polyvinyl chloride (PVC) plastic. New technology combining ESO with common phosphoric acid and water to make relatively inexpensive soy phosphate ester polyols is proving useful in coatings, inks, adhesives, and possibly as a concrete additive. Waterborne soy phosphate polyol/alkyd coatings improve corrosion resistance and adhesion to metals and minerals and reduce VOC emissions. Hyperbranching and multiple hydroxy groups (about eight per oil molecule) give excellent cross-linking for hardness, solvent resistance, and high-solids coatings.

Figure 25. United Soybean Board Success Stories: Commercial Products from Soybeans 


\subsection{Oleochemical Biorefineries}

Oleochemical plants are mature biorefineries. In fact, the origin of organic chemistry began with fats and oils. Fats and oils are generally split into their fatty acid and glycerol fractions via one of two routes: hydrolyzing (called splitting in the industry) and methyl ester production (Figure 26). The fatty acids and fatty acid methyl esters are used to produce a wide variety of secondary platform compounds, including fatty acids, other esters, fatty alcohols, fatty amines, and glycerol. ${ }^{58}$ From these intermediates, literally thousands of chemicals and products are produced for nearly every industry in the United States, although typically they are grouped according to classes of compounds (Figure 26). There is nothing preventing biodiesel plants from becoming oleochemical plants other than access to more sophisticated management, technology, and markets.

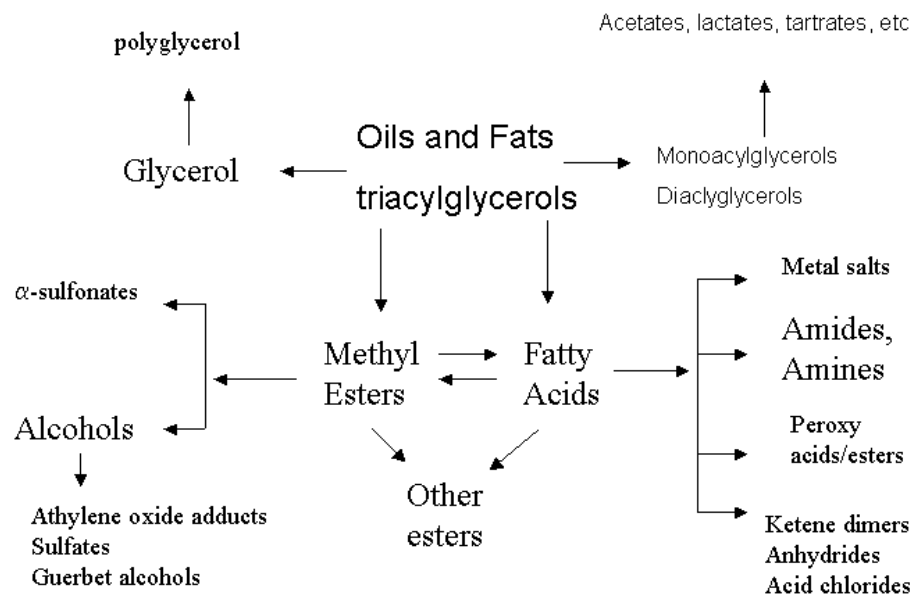

Figure 26. Inter-relationships Between Triaclyglycerols and their Derivatives

The oleochemical industry consumes 2.6 billion pounds of fatty acids (Table 30 ) to produce almost 4 billion pounds of plastics, lubricants, detergents, solvents, and other useful industrial and consumer products (Table 31 ). The oleochemical industry also produces byproduct glycerol, used in cosmetics, pharmaceuticals, and other high value uses. An overview of the oleochemical product lines and their uses is provided in Appendix A.

Making higher value derivatives from methyl esters produces additional profits for an oleochemical plant, but that does not make methyl esters any less expensive to produce. Nearly $99.5 \%$ of the available fatty acids in triglyceride feedstocks are converted into methyl esters. Each methyl ester is already directed into its highest value use as the oleochemical plants optimize their product slates depending on consumer preferences and market signals. Some of the average costs of production may be spread over more products, but quite frankly, the more

\footnotetext{
${ }^{58}$ Gunstone, Frank, D. "Basic Oleochemicals, oleochemical products, and new industrial oils." in Oleochemical Manufacture and Applications. 2001, Sheffield Academic Press.
} 
products a firm producers the higher the investment costs. Investors may find higher profits in producing oleochemicals compared to methyl ester intermediates or even methyl ester fuels, but this does not reduce the underlying cost structure for making the methyl esters themselves. The only way to make methyl esters less expensive is to reduce the price of oils used to produce them.

Table 30 North American Consumption of Fatty Acids by Market Segment ${ }^{59}$

\begin{tabular}{|l|c|}
\hline Use & Consumption $\left.\mathbf{( 1 0}^{\mathbf{6}} \mathbf{~ I b} \mathbf{- 2 0 0 0}\right)$ \\
\hline \hline Personal care products & 631 \\
\hline Industrial lubricants, corrosion, oilfield & 292 \\
\hline \hline Plastics & 266 \\
\hline Cleaners & 251 \\
\hline Coatings and adhesives & 184 \\
\hline Fabric softeners & 184 \\
\hline Emulsion polymers & 102 \\
\hline Foods & 92 \\
\hline Rubber & 86 \\
\hline Paper & 81 \\
\hline Crayons, candles, waxes & 59 \\
\hline Mining & 56 \\
\hline \hline Animal feed & 40 \\
\hline \hline Textiles & 34 \\
\hline \hline Asphalt & 34 \\
\hline Buffing compounds & 25 \\
\hline Agricultural & 22 \\
\hline Exports & 92 \\
\hline \hline Other & 84 \\
\hline Total & 2,615 \\
\hline
\end{tabular}

\subsubsection{Glycerol Contribution to Biorefineries}

Glycerol (1,2,3 propanetriol) is an unavoidable byproduct of producing fatty acid products and fuels. Most (97\%) of the glycerol used today is a highly refined product ( $97 \%+$ purity).

Purification costs are high ( $\$ 400$ per ton) and glycerol prices range between $\$ 0.60$ and $\$ 0.90$ per pound. As a result of its high price, most glycerol product markets are small and fragmented.

Crude glycerin (50\% to $90 \%$ glycerol by weight) sells at a discount to USP prices, depending on the glycerol content of the product, the amount and type of contaminants present, and supply and demand balances. Biodiesel producers receive between 5 and 15 cents/lb for crude glycerin $(50 \%$ glycerol) and $80 \%$ to $88 \%$ refined sells for between 30 and 40 cents/lb. Odor, color, and contaminants from yellow grease and animal fat feedstocks reduce the value of glycerin produced from these feedstocks.

\footnotetext{
${ }^{59}$ SRI International, Chemical Economics Handbook, "Natural Fatty Acids."
} 
Table 31. Fatty Acid Compounds Produced by Oleochemical Industry

\begin{tabular}{|l|c|l|c|}
\hline Fatty Acid Compound Classes & $10^{6} \mathrm{lbs}$ & Fatty Acid Compound Classes & $10^{6} \mathrm{lbs}$ \\
\hline Fatty acids and soaps & 1094 & Other fatty acid compounds & 10 \\
\hline Quaternary Ammonia Salts & 101 & Alcohol ethoxylates & 805 \\
\hline Amines, diamines, ethoxylated amines & 103 & Alcohol sulfates & 60 \\
\hline Esters & 353 & Polymethacrylate esters & 25 \\
\hline Fuel Esters & 165 & Fatty nitrogen derivatives & 20 \\
\hline Metal Salts & 239 & Alcohol glyceryl ether sulfonates & 16 \\
\hline Monomer, dimer, trimer acids & 211 & Alkylpolyglucosides & 16 \\
\hline Ester quats & 144 & Hindered phenols & 8.5 \\
\hline FA polyamine condensates and quats & 114 & Thiodpropionate esters & 6 \\
\hline Anionic surfactants & 87 & Other & 15.5 \\
\hline Fatty acid amides & 86 & Free alcohols, C12 - C18 & 41 \\
\hline Amphoteric surfactants & 52 & C2o+ alcohols & 20 \\
\hline Short chain fatty acids & 48 & Consumer inventory & 3,876 \\
\hline Alkyl ketene dimers & 33 & Total & \\
\hline
\end{tabular}

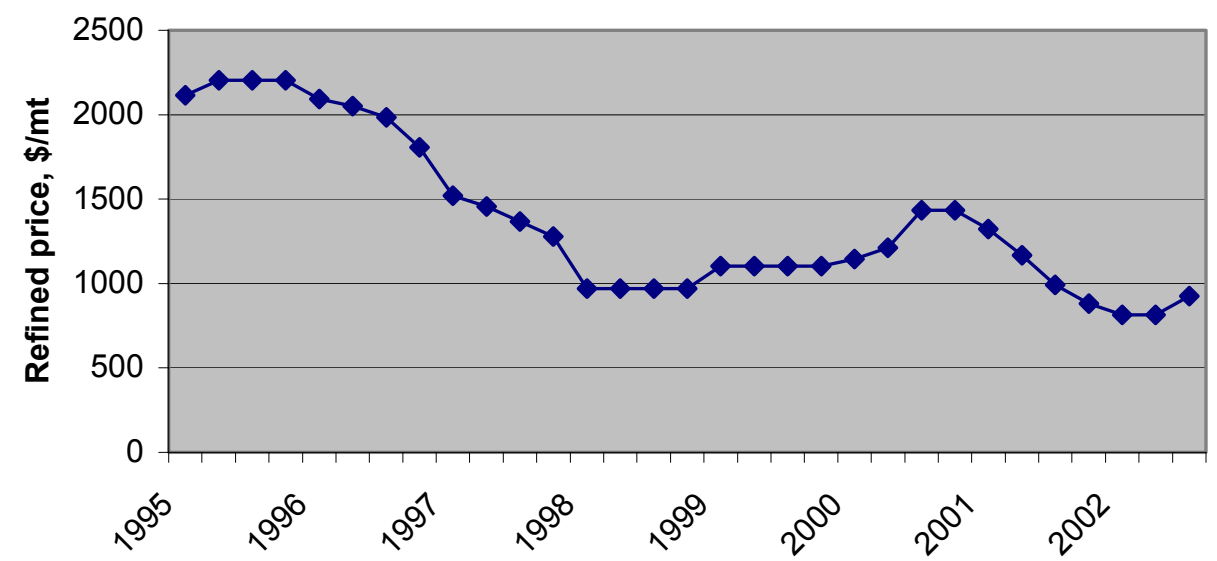

Figure 27. Recent Glycerol Price History ${ }^{60}$

Small increases in fatty acid consumption for fuels and products can increase world glycerin production significantly (Table 32). The expansion of biodiesel in Europe in recent years has had a major impact on glycerol prices (Figure 27). If the United States displaced 2\% of the on-road diesel with biodiesel in a B2 policy by 2012 , almost 1.1 billion gallons of B100 would be used

${ }^{60}$ Proctor and Gamble presentation, July 17, 2003. 
and 800 million pounds of new glycerol supplies would be produced. ${ }^{61}$ Current domestic production of natural glycerol was 249.2 million pounds in $2002 .^{62}$ Thus, a B2 policy could potentially quadruple domestic glycerol production. In fact, regardless of United States biodiesel policy, world production of biodiesel is likely to increase in S. America, Australia, Southeast Asia, Asia, the former USSR, Africa, and elsewhere. Biodiesel production from local soy and palm oils can be cost effective in many countries with high petroleum prices or poor balance of payment positions due to petroleum imports (in United States dollars).

Table 32. Projected Impact on United States Glycerol Supplies from Biodiesel

\begin{tabular}{|c|c|c|}
\hline $\begin{array}{l}\text { Biodiesel } \\
\text { Millions of } \\
\text { Gallons }\end{array}$ & $\begin{array}{l}\text { Glycerol } \\
\text { Millions of } \\
\text { Pounds }\end{array}$ & $\begin{array}{l}\text { Percentage of United States } \\
\text { Production 2002 }\end{array}$ \\
\hline \hline 250 & 184 & 73.7 \\
\hline 500 & 368 & 147.5 \\
\hline 750 & 551 & 221.2 \\
\hline \hline 1,000 & 735 & 294.9 \\
\hline 1,500 & 1,103 & 442.4 \\
\hline 2,500 & 1,838 & 737.4 \\
\hline
\end{tabular}

The lowest price that crude glycerin will fall to is $5 \mathrm{c} / \mathrm{lb}$, because at that value steam reforming to hydrogen, animal feed, and other values could create large markets for crude glycerin. Glycerol prices can fall to $20 \mathrm{c} / \mathrm{lb}$, the industry average cost for refining glycerol today. ${ }^{63} \mathrm{P} \& \mathrm{G}$ projects glycerol prices may fall to $50 \mathrm{c} / \mathrm{lb}$ by 2010 because of biodiesel expansion. If glycerol prices drop into the $20-50 \mathrm{c} / \mathrm{lb}$ range, it can become a major platform chemical.

Converting glycerol into new products could preserve profits within all types of methyl ester plants - biodiesel and oleochemical. Most chemicals made from glycerol today are made from USP glycerol $(95 \%+$ purity). In order for biodiesel firms to produce coproducts, an inexpensive method for refining glycerol needs to be developed. Otherwise, the crude glycerin ( $80 \%$ to $88 \%$ purity) will be sold to toll refiners who might invest in new product conversion technology.

There are two schools of thought about glycerin coproduct strategies. They can be referred to as the high volume-low value theory and the low volume-high value theory. Researchers at NREL and DOE believe that long-term markets for large volume intermediate chemicals, such as glycerol, should focus research on lower value products $(50 \mathrm{c} / \mathrm{lb})$ in order to move that quantity of material into the market place. Industry, on the other hand, believes that profits are created and protected by developing as many high-value, low-volume markets as possible. The two strategies are both correct; successful firms will invest in both. In fact, investing in the profit maximizing strategies first can provide a future income stream for investing in endeavors with larger volume and lower value glycerol products in the future. In defense of the DOE/NREL

\footnotetext{
${ }^{61}$ Based on projected

${ }^{62}$ Chemical Economics Handbook, Glycerin, SRI International, February 2003.

${ }^{63}$ Glycerol refining costs for industry provided by Proctor \& Gamble, July 17, 2003.
} 
position, federal investment is not needed in the high value product market, but it's involvement is justified in the lower value, higher volume markets because it will be more difficult for private technology developers to recover costs from low-profit margin products and the benefits may be dispersed among many competing firms. In the case of biodiesel, if the development of high volume coproducts lags the biodiesel market growth, gluts in the glycerol markets could set the biodiesel industry back.

Some researchers are focusing attention on uses and products that the crude glycerin is suitable for with minor processing. For example with some simple ion exchange technology the salty glycerin can be modified for deicers and anti-icers for airport use. This new product is being tested now in a Midwest airport. Potential markets could consume up to 200 million gallons of glycerol per year.

\subsubsection{New Chemical Modifications of Glycerol}

There is a tremendous potential to develop a variety of new processes and product lines from glycerol, taking advantage of its unique structure and properties. Glycerol is a nontoxic, edible, biodegradable compound. These characteristics provide important environmental benefits to new platform products. Most products are based on unmodified glycerol or simple modifications to the glycerol molecule. More complex chemistry was hindered by its high cost. Lower cost glycerol could open significant markets in polymers, ethers, and other compounds.

From a technical standpoint, glycerol's multifunctional structure can be exploited by several different means, as shown by the potential glycerol product family in Figure 28. It is clear that a very large number of products and product classes could, in principle, be derived from glycerol. However, an attempt has been made in this section to avoid simply listing each of the many separate structures. Instead, the very large number of product opportunities and types of technology that could be brought to bear on glycerol has been focused into three larger categories that lead to clearer definition of barriers. Because this becomes product oriented $\mathrm{R} \& \mathrm{D}$, objectives and goals should be set in partnership with industry. 


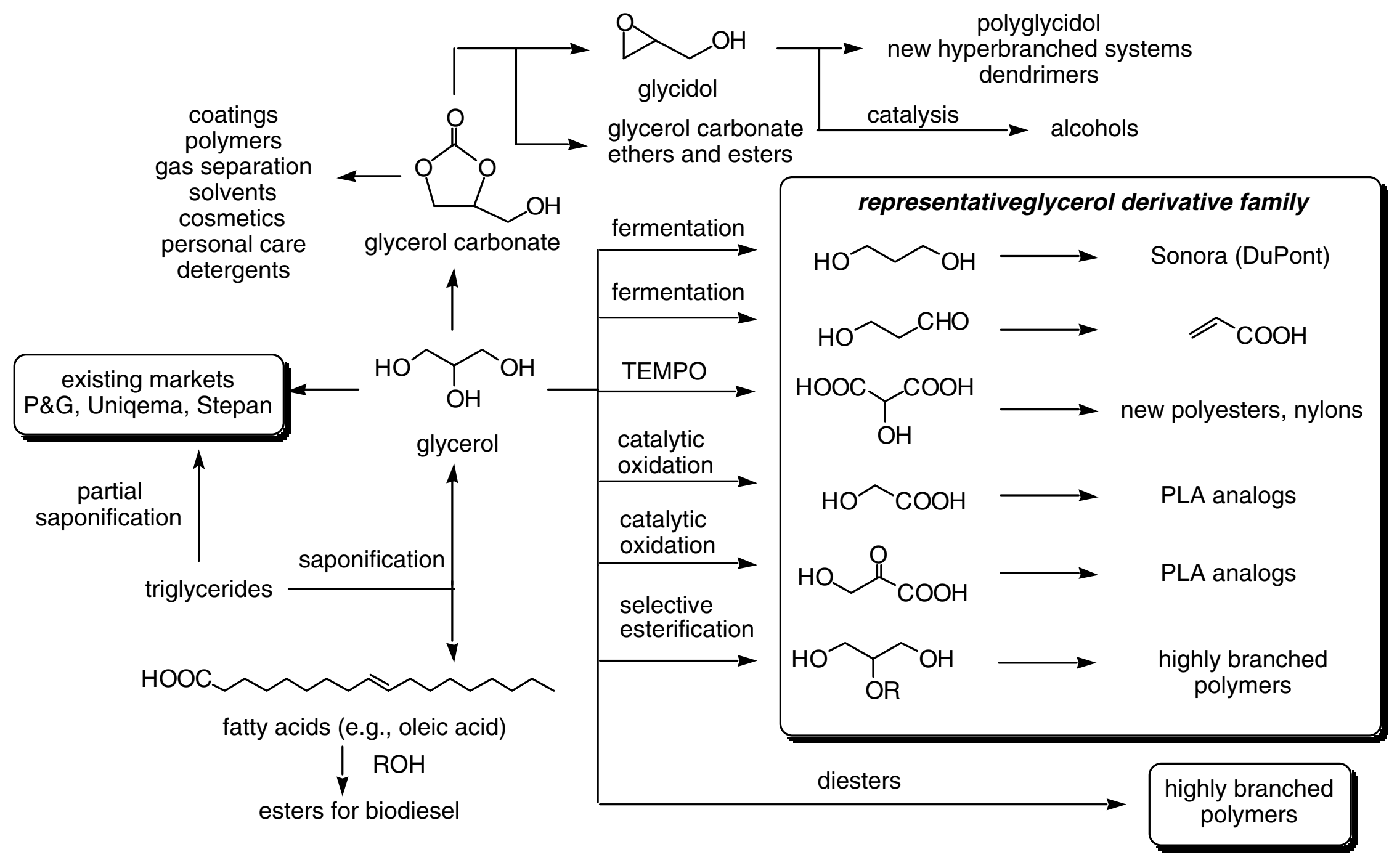

Figure 28. Families of Possible Glycerol Reactions 


\subsubsection{Selective Oxidation of Glycerol}

Glycerol's structure lends itself to catalytic oxidative processes using inexpensive oxidizing agents such as air, oxygen, hydrogen peroxide, or bleach. Combining these inexpensive oxidizing agents with an inexpensive source of glycerol will allow the production of a number of new derivatives. A few research groups have investigated this technology, but their focus has been limited to a small number of catalysts, leaving a number of questions of selectivity and yield unanswered. ${ }^{64}$

\subsubsection{Glycerol Carbonate as a New Solvent and Product}

Glycerol carbonate is a relatively new material in the chemical industry, but one that could offer some interesting opportunities, as it can be prepared directly and in high yield from glycerol. Glycerol carbonate has been investigated as a novel component of gas separation membranes, polyurethane foams, ${ }^{65}$ as a surfactant component,${ }^{66}$ as a new solvent for several types of materials, as a component in coatings, as a potential component of the paint industry, as a nonvolatile reactive solvent, and as a component of detergents. As glycerol becomes less expensive, the use of glycerol carbonate in applications occupied by currently cheaper carbonates should be investigated. Dimethyl carbonate is being positioned as a green replacement for phosgene in the production of polycarbonates and polyurethanes. Inexpensive glycerol carbonate could serve as a source of new polymeric materials for this industry. Glycerol carbonate can be prepared by very simple processes, such as the direct reaction of glycerol with urea ${ }^{67}$ or the treatment of glycerol with ethylene or propylene carbonate. ${ }^{68}$ Direct production of glycerol carbonate from glycerol and carbon dioxide under supercritical conditions has also been reported. ${ }^{69}$ Interestingly, glycerol carbonate has also been prepared from nonglycerol starting materials, such as epichlorohydrin ${ }^{70}$ or tricaprylin. ${ }^{71}$

\subsubsection{Glycerol as a Component of New Polymers}

Glycerol has traditionally played a role in the production of several types of polymers, some of which are available commercially. Selective etherification reactions can convert glycerol into polyglycerol esters, which have been suggested for use as biodegradable surfactants and lubricants $\mathrm{s}^{72}$ and as replacements for conventional poly(oxoethylene) nonionic surfactants.

${ }^{64}$ Kimura, H.; Tsuto, K.; Wakisaka, T.; Kazumi, Y.; Inaya, Y. Appl. Catal. A 1993, 96, 217; Kimura, H. Appl. Catal. A 1993, 105, 147; Gallezot, P. Catal. Today 1997, 37, 405; Garcia, R.; Besson, M.; Gallezot, P. Appl. Catal. A 1995, 127, 165; Besson, M.; Gallezot, P. Catal. Tod 2000, 57, 127; Fordham, P.;

Besson, M.; Gallezot, P. Stud. Surf. Sci. Catal. 1997, 108, 429; Abbadi, A.; van Bekkum, H. Appl. Catal. A 1996, 148, 113; Srivastava, S.; Tripathi, H.; Singh, K. Trans. Met. C. 2001, 26, 727.

${ }^{65}$ Randall, D.; De Vos, R. Eur. Pat. EP 419114 to Imperial Chemical Industries PLC, UK (1991).

${ }^{66}$ Weuthen, M.; Hees, U. Ger. Patent DE 4335947 to Henkel K.-G.a.A., Germany (1995)

${ }^{67}$ Okutsu, M.; Kitsuki, T. World patent WO 0050415 to Kao Corp., Japan (2000).

${ }^{68}$ Mouloungui, Z.; Yoo, J.-W.; Gachen, C.-A.; Gaset, A.; Vermeersch, G. European patent EP 739888 to Organisation Nationale Interprofessionnelle Des Oleagineux- Onidol, Fr. (1996).

${ }^{69}$ Vieville, C.; Yoo, J. W.; Pelet, S.; Mouloungui, Z. Catal. Let. 1999, 56, 245.

${ }^{70}$ Kanetani, K. Japan patent JP 01165582 to Nippon Polyurethane Industry Co., Ltd., Japan (1989).

${ }^{71}$ Renga, J. M.; Coms, F. D.; Humphreys, E. R. World patent WO 9309111 to Henkel Corp., USA (1993).

${ }^{72}$ Clacens, J.-M.; Pouilloux, Y.; Barrault, J. Appl. Catal. A 2002, 227, 181; Kunieda, H.; Akahanem, A.; Feng, J.; Ishitobi, M. J. Coll. Interfac. Sci. 2002, 245, 365 
Polyglycerol and polyglycerol methacrylates are used as treatments for wood to improve its stability. ${ }^{73}$ This application would compete with the more widely used polyethyleneglycols. However, glycerol based polymers offer additional benefits including lower amounts of leachability into the environment. ${ }^{74}$ As the cost of glycerol decreases, processes to manufacture polyglycerols through modification of its structure become more affordable, and would lead to new optimized wood treatments.

More recently, significant attention is being given to preparation and properties of new, more highly branched polymers. Glycerol's multifunctional structure is well suited for the production of these new types of polymers, and preliminary work at NREL has demonstrated the production of new glycerol based polymers, and the ability to control the properties that they exhibit. In addition, glycerol has been used with lactic acid to prepare branched polylactide polymers. ${ }^{75}$

More generally, branched polymers exhibit a wide range of new properties that could be exploited in useful marketplace products. Table 33 lists a number of physical properties that have been observed in highly branched systems, and suggests how these properties could be translated into properties of interest in production and commercialization.

A number of more specific product application areas have been suggested for branched polymers. Many of these could be very high value applications, such as use in sensors, personal care products, or organic conductors. However, the volume of such materials will be fairly low, thus, while they might help the profitability of a glycerol unit operation, they would not be able to offer a significant consumption of large amounts of glycerol. Other applications in larger volume markets have been suggested, and branched polymers could find utility as polyester polyols, surfactants, coatings, and alkyd resins, new solvents, and polyurethanes. Each of these market areas is very large (Table 34).

Table 33. Translation of Branched Polymer Physical Properties into Potential Marketplace Utility

\begin{tabular}{|c|c|}
\hline Physical property & Potential product interest \\
\hline Lower solution viscosity & Easier processibility \\
\hline Higher amorphous content & Higher reactivity \\
\hline More end groups & Greater property control \\
\hline Higher organic solubility & More versatility in processing \\
\hline Novel 3-D architecture & New material properties \\
\hline Large number of functional groups & Easier functionalization \\
\hline
\end{tabular}

New highly branched polymers have been made using glycidol as a starting monomer. The resulting structure is a branched polyether polyol, but is frequently referred to as a

\footnotetext{
${ }^{73}$ Morlat, S.; Cezard, N.; Loubinoux, B.; Philippart, J.-L.; Gardette, J.-L. Poly. Degrad. Stab. 2001, 72, 199.

${ }^{74}$ Roussel, C.; Marchetti, V.; Lemor, A.; Wozniak, E.; Loubinoux, B.; Gerardin, P. Holzforschung 2001, $55,57$.

${ }^{75}$ Arvanitoyannis, I.; Nakayama, A.; Kawasaki, N.; Yamamoto, N. Polymer 1995, 36, 2947.
} 
polyglycerol. ${ }^{76}$ Glycidol is a high value component in the production of a number of polymers, including epoxy resins and polyurethanes. Glycidol has been conventionally synthesized from epichlorohydrin, which in turn is derived from the chlorination of allyl alcohol. More recently the high yield preparation of glycidol from glycerol carbonate, and thus, from glycerol, has been reported, making it likely that low cost glycerol could be used to produce low cost glycidol and its family of products. ${ }^{77}$ Small scale production of these highly branched glycidol polymers has been commercialized in Europe by Hyperpolymers (Germany).

Table 34. - Sizes of Various Market Segments Related to the Use of Branched Polymers

\begin{tabular}{|l||l|l|}
\hline Market segment & Market size $\mathbf{( 1 0}^{\mathbf{6}} \mathbf{~ I b )}$ & Year \\
\hline Polyether polyols & 7643 & 2001 \\
\hline \hline Polyester polyols & 463 & 2001 \\
\hline \hline Surfactants & 1742 (detergents only) & 2000 \\
\hline \hline Alkyd resins and coatings & 1691 & 2000 \\
\hline \hline Polyurethane foam & 3410 & 2001 \\
\hline \hline Polyurethane elastomers & 433 & 1997 \\
\hline
\end{tabular}

Using glycerol as a starting material for the production of other small molecules also offers a new opportunity. Glycidol has the advantage of being a current commercial, albeit specialty product. Lowering its cost by producing low cost glycerol presents new opportunities to further expand of the glycerol product family. For example, extensive work has been carried out on catalytic transformations of epoxides. Should the cost of glycerol, and thus, the cost of glycidol drop, it will become important to investigate the ability of these processes to convert glycidol into a source of alcohols and other epoxide derivatives. ${ }^{78}$

\subsubsection{Selective Reduction Processes}

Recent work carried out at NREL offers the opportunity to tailor catalytic reduction processes to selectively convert glycerol into 1,3-propanediol. While this work is currently in the developmental stage, the more general ability to selectively transform a single structural unit within glycerol using catalysis would be highly valuable. More generally, this type of selective transformation would also be of great value in learning how to more efficiently transform the products of the sugar platform into new marketplace products.

\subsubsection{Biochemical Transformations}

Glycerol can also serve as a feedstock in biochemical transformations. Glycerol has been investigated for the fermentative production of 1,3 propanediol, one of the primary components

\footnotetext{
${ }^{76}$ There is confusion in the literature regarding this terminology, because it is also possible to start with glycerol and produce a different type of polyglycerol directly. See Clacens, J.-M.; Pouilloux, Y.; Barrault, J. Appl. Catal. A 2002, 227, 181.

${ }^{77}$ Yoo, Jeong-Woo; Mouloungui, Z.; Gasset, A. World patent WO 9840371 to Organisation Nationale Interprofessionnelle des Oleagineux (O.N.I.D.Ol.), Fr. (1998).

${ }^{78}$ Sajiki, H.; Hattori, K.; Hirota, K. Chem. Comm. 1999, 1941.
} 
of DuPont's Sonora (1,3 PDO and terephthalic acid), a polymer being investigated for use in textiles and carpeting. Interestingly, the first reports of commercial PDO production were from Shell and their process for making Corterra, also based on PDO and terephthalic acid. ${ }^{79}$ This is by no means a new process. Fermentation of glycerol to PDO was described as early as $1881 .^{80}$ Simple economic evaluation indicates that biochemical PDO production would be more economical than chemical PPO production. ${ }^{81}$

A primary question for this application area is the proper choice of biochemical feedstock. Current prices of glycerol imply that an alternate fermentative route from glucose would give cheaper 1,3-PDO. Moreover, the ability to produce glycerol fermentatively suggests that glycerol and PDO production might be carried out from glucose by a single organism, which may be the basis of the DuPont commercialization effort. ${ }^{82}$ These attempts are based on the assumption that glucose will always be cheaper than glycerol. However, we have no good projections, as yet, as to the cost of glycerol as a result of a large scale oleochemistry industry producing biodiesel in large amounts and coproducing glycerol. Nonetheless, considerable effort has been carried out to improve biochemical PDO production. Cameron has reported that minimizing the amount of methyl glyoxal and glycerol-3-phosphate produced during fermentation using engineered $E$. coli improves the conversion of glycerol to PDO by removing these two enzyme inhibitors. ${ }^{83}$

Cameron has also described engineering E. coli for the production of 1,2-propanediol, a material with an annual market of over 1 billion $1 b .{ }^{84}$ This process proceeds through dihydroxyacetone as a metabolic intermediate, implying that proper choice of organism could lead to either 1,2- or 1,3-PDO from glycerol, since one of the first intermediates in 1,3-PDO production is also dihydroxyacetone. $^{85}$

One of the drawbacks to production of 1,3-PDO from glycerol is that most organisms require a purified glycerol source. The so-called "industrial" glycerol, available directly from biodiesel production or oleochemical facilities, is frequently contaminated with salts from transesterification, which inhibits the biochemical process. Various research groups are attempting to solve this limitation with new fermentative organisms. ${ }^{\mathbf{8 6}}$

The traditionally high price of glycerol limited the economic viability of such transformations except for products used in high value niche markets: cosmetic additives, tanning agent components, amino acid precursors, or selective metal chelants. As glycerol prices fall, industrial/government partnerships to develop new products and identify large market uses provides mutual benefits. For example, NREL has specific expertise in the development of new catalytic oxidations based on novel polyoxometallate catalysts, and the use of simple radical

\footnotetext{
${ }^{79}$ Biebl, H.; Menzel, K.; Zeng, A.-P.; Deckwer, W.-D. Appl. Microbiol. Biotech. 1999, 52, 289.

${ }^{80}$ Freund, A. Monatsh. Chem. 1881, 2, 636.

${ }^{81}$ Deckwer, W.-D. FEMS Microbiol. Rev. 1995, 16, 143.

${ }^{82}$ Biebl, H.; Menzel, K.; Zeng, A.-P.; Deckwer, W.-D. Appl. Microbiol. Biotech. 1999, 52, 289.

${ }^{83}$ Zhu, M. M.; Lawman, P. D.; Cameron, D. C. Biotechnol. Prog. 2002, 18, 694.

${ }^{84}$ Altaras, N. E.; Cameron, D. C. Appl. Environ. Microbiol. 1999, 65, 1180.

${ }^{85}$ Cameron, D. C.; Altaras, N. E.; Hoffman, M. L.; Shaw, A. J. Bitechnol. Prog. 1998, 14, 116.

${ }^{86}$ Papanikolaou, S.; Ruiz-Sanchez, P.; Pariset, B.; Blanchard, F.; Fick, M. J. Biotech. 2000, 77, 191;

Petitdemange, E.; Andaloussi, S. A.; Raval, G. J. Ind. Microbiol. 1995, 15, 498.
} 
based oxidations of polyols, which have been examined as new types of nylons. ${ }^{87}$ As their cost drops, these intermediates can be considered as components of new polyfunctional, glycerolderived polymers, such as polyesters and nylons. Other selective oxidation products may find applicability as structural analogs of polylactic acid.

\subsection{Feedstock Integration with Biorefineries}

USDA and agricultural scientists have already introduced a low-linolenic acid soy variety that improves oil storage stability for both food and fuel use. They are also introducing other varieties with new oil compositions, such as a highly saturated soy oil to reduce hydrogenation, which creates trans fatty acids. The primary purpose of these new varieties is to meet consumer food demands and thus, the production cost of identity preserved soy varieties can be borne by these high value markets. Over time, these varieties may become mainstream, eliminating the identity preservation costs and making these improved traits available to the energy industry.

Similarly, crop breeders are also producing new varieties of soy and other oil seeds to improve oleochemical product value. Increasing linolenic acid content of some soy varieties makes soy oil similar to linseed oil. Linolenic and linolenic acids are the new intermediate fatty acid substrates for a rapidly expanding set of monomer and polymer chemistries. These efforts are designed to expand the use of biomass oils to produce new biobased products based on the exploitation of unsaturated fatty acids. Most of the chemistries focus on bonding alcohols, hydroxyls, expoxyls, and other molecules to the $\mathrm{C}=\mathrm{C}$ sites on these unsaturated fatty acids. The resulting compounds are then able to interlink, cross-link or exhibit otherwise desirable properties for a wide range of new uses.

Historically, oleochemistry exploited the production of chemical derivatives of saturated fatty acids, since tallow and lard were the most readily available and least expensive of the industrial biomass oils. The soy industry didn't emerge as a commercial industry in the United States until after WWII, so seed oils were expensive and limited to human consumption. As the market prices for soy and other seed oils trend downwards with expanding world production, unsaturated fatty acids are becoming more affordable as substrates for biobased products and new chemistries.

Castor has been grown in the United States in small quantities but it is currently limited by competition with foreign imports and low demand for its meal. Castor bean meal contains a potent neurotoxin, ricin, which is extremely poisonous to living organisms. The meal is typically steam treated to reduce ricin concentrations from $0.8 \%-1 \%$ to less than $10 \mathrm{ppm}$. Because so many other animal meals are available, few livestock producers take the risk of using castor meal and trusting the quality control of the castor-crushing mill.

USDA has a research program underway to removing the ricin gene from castor plants, although the risk of cross-pollination from backyard castor plants remains an issue. Castor is a desirable oil because it contains $50 \%$ to $80 \%$ hydroxyl acids (ricinolic acid) which eliminates the hydroxylation step used with soy oil. These ready-made polymer substrates are desirable for a

${ }^{87}$ For example, see Morton D. W.; Kiely D. E. J. Appl. Polym. Sci. 2000, 77, 3085. 
wide range of uses in oleochemicals and petrochemicals. Castor oil can be made into esters, but castor esters cannot be used as biodiesel for several reasons:

1. The definition of biodiesel does not include branched fatty acids such as ricinolic acids

2. The key property of castor oil is that is it rapidly polymerizes at relatively low temperatures, not a desirable trait in combustion.

Since the oleochemical industry already consumes 4 billion pounds of biomass oils, expanding these product lines through crop modifications is best done in partnership with the chemical production company and local crop breeders. Most oleochemical markets are narrowly defined by specifications and offer limited market potential in terms of volume. In aggregate they are quite large, by specific chemical or compound they are small. Focusing research on oleochemical products will be a very expensive way to displace a small amount of oil.

Modifying the structure of saturated fatty acids to selectively introduce one double bond at a specific location will make saturated feedstocks more amenable to B20 markets and new product technology that uses polyunsaturated feedstocks. While not a supply expansion per se, it expands market opportunities for saturated feedstocks. The possibility for selective placement of a double bond on a similar molecular structure via enzymatic technology has been demonstrated on similar molecular structures but not on palmitic or steric acids. Other processes from the petrochemical industry may also be considered as possible approaches. If biodiesel markets are primarily low blends, this new technology may not be needed. Since oil displacement is maximized with low blend markets, developing this technology is not a DOE priority but remains a useful research goal for others or an SBIR project. 


\section{CONCLUSIONS}

The conclusions of this analysis can guide OBP R\&D investments in alignment with their goals and desired outcomes.

- There has to be a clear policy environment that encourages the use of biomass oil fuels and products using tools such as purchasing incentives, tax credits or mandates. Mandates will be the least expensive of the options but incentives are more politically popular. Some realignment of other subsidies, such as oil and soybean export incentives and farm support payments could be redirected into incentive programs. Long-term incentive costs depend on the differential between biomass oil prices and distillate prices as crude oil prices rise.

- Without incentives, there is no justification for significant DOE R\&D in an oils platform, since $R \& D$ can make only minor reductions in feedstock costs and oil displacement will be limited.

- Biomass oils can displace up to 10 billion gallons of petroleum by 2030 if incentives or mandates are used to promote fuels and biobased products produced from biomass oils. USDA crop research in sunflower, canola and other high oil content seeds will be needed to reach this potential production level.

- In order for biomass oils to displace large quantities of petroleum there must be a wellcoordinated research program between USDA and DOE.

- Biomass oils can be used as fuels in a variety of ways: directly as boiler fuels, processed into biodiesel (fatty acid methyl esters), or processed into "bio-distillates" via refinery technology.

- With incentives, both biodiesel and bio-distillates offer major oil displacement potential. One fuel is not exclusive of the other, as regional and local market conditions may favor one fuel over the other.

- Blends of biomass oil fuels with petroleum fuels offer the best commercial potential because blends offer superior performance and lower cost than the straight biomass oil fuels themselves.

- The oleochemical industry has already commercialized biomass oil biorefineries. This mature industry consumes 2.6 billion pounds of biomass oils and produces near 4 billion pounds of biobased products, chemicals, fuel additives, and biodiesel annually.

- Oleochemicals compete with petrochemicals in many markets on price and performance basis (detergents, lubricants, solvents, coatings, polymers, etc). Biobased purchasing incentives or financial incentives that reduce biomass oil feedstock costs vis-à-vis petroleum feedstock costs could increase demand for oleochemical products and displace 
some petrochemical products. There is some potential to increase the oleochemical content of some petrochemical products as well.

- Methyl esters (aka biodiesel) is one of two primary platform chemicals for the oleochemical industry. The production of methyl esters is highly efficient (yields exceeding 99.7\%) and their total average production costs are minimized given the constraints of feedstock costs and economies of scale. Investments in processing technology have a limited impact on production costs.

- Glycerin (a crude mixture of glycerol and other impurities) is an inevitable coproduct of biodiesel and oleochemical production. Federal investment in biodiesel catalyst R\&D, in particular, fixed base catalysts and fixed dual-purpose acid-base catalysts can improve glycerin coproduct quality and reduce glycerin refining costs. In turn, this can expand the ability of biodiesel plants to produce glycerol-base coproducts and generate higher values for their glycerol streams.

- Biodiesel expansion will flood United States and international markets with glycerin. Federal investments in new uses for glycerin and new products produced from glycerol can enable the rapid expansion of a biodiesel or oleochemical industry.

- Methyl esters are used to produce a wide variety of fatty acid coproducts, however, fatty acid coproducts revenues cannot be leveraged to reduce methyl ester production costs. Oleochemical firms will not use coproduct profits to subsidize fuel prices (the breakeven approach to fuel cost estimation). Coproducts generate profits, increase returns to equity, and generally attract investment in biobased product expansion.

- The mature status of the oleochemical industry stymies the typical rationales for biobased product investment. There are opportunities to invest in new oleochemical technologies, particularly in research focused on unsaturated fatty acid feedstocks. However, it is difficult to make the argument that the oleochemical industry lacks the technology or resources to make these investments themselves. Federal investment in fatty acid product research should be focused on displacing petroleum, by displacing petrochemicals, by reducing energy processing costs, or both to bring investments in line with both EERE goals.

- Federal investment can expand the future supplies of biomass oils through crop R\&D with a focus on increasing yields and reducing costs of high oil seed crops (canola, sunflower, etc.) increasing oil content of soy beans, increasing demand for soy bean meal, and investments in manufactured oils from yeasts, fungus, bacteria and similar microorganisms that can be produced with minimal land or sunlight investments.

- Federal investment can reduce the cost of biomass oil feedstocks (for fuel and biobased products) through $R \& D$ to increase crop yields and reduce production costs of high oil content seeds (canola, sunflower, etc.), increasing demand for soy bean meal via coproduct development, and investments in manufactured oils from yeasts, fungus, 
bacteria and similar microorganisms that can be produced with minimal land or sunlight investments.

- Unless an industry partner is willing to assume the costs of commercializing new fuel or fuel additive products, federal investment in these two areas should be avoided. The commercialization costs of new fuels and fuel additives can equal or exceed $\$ 30$ million.

- Federal investments in lubricants, fuels and other products should be compared on a basis of petroleum displacement $(\$ / \mathrm{bbl})$ to determine the value and rank biobased product and fuel programs. Many investments in lubricant development are made minuscule in comparison to the costs of commercializing the products and the resulting market share can be quite small in terms of oil displacement. 


\section{RESEARCH RECOMMENDATIONS}

If incentives or mandates for biomass oil fuels or products emerge, there are a number of key R\&D areas that will support biomass oil cost reduction, supply expansion or both. Key research areas are:

1. Reduce production costs for canola, sunflower, and other high oil seed crops by developing pesticide resistant strains and more drought tolerant crops

2. Increase seed yield per acre for canola, sunflower, and other oilseed crops grown through breeding, site optimization, and improved management technology

3. Continue improving soybean production costs and seed yields

4. Develop higher oil content soybeans

5. Develop crops that do not require land or sunlight (high oil bacteria, yeast, fungi, molds)

6. Develop and commercialize less expensive, yet highly efficient, oil extraction from seeds

7. Develop and commercialize less expensive, yet highly efficient, oil extraction from animal byproducts

8. Develop and commercialize higher value coproducts from seed meals

9. Develop and commercialize higher value coproducts from animal meals

10. Develop and commercialize cost efficient separation technology for meal coproducts

11. Develop and commercialize biodiesel technology that improves crude glycerin quality

12. Invest in industry shared $R \& D$ on large volume glycerin coproduct development

13. Invest in industry shared R\&D to develop biodiesel blend standards

14. Work with industry partners to assess low blend infrastructure costs and needs

15. Work with industry partners to demonstrate and test bio-distillates production technology

16. Work with industry partners to demonstrate and test bio-distillates product quality

Many of these research areas are best suited to the skills developed by researchers at USDA. Those that are best suited for the expertise established at DOE laboratories and DOE industrial partnerships include the following:

1. Demonstrate and optimize commercial bio-distillate production

2. Demonstrate and optimize CO2 oil extraction technology

3. Develop and optimize fixed base and acid-base esterification catalysts that reduce glycerin refining costs

4. Support industry development of coproducts from glycerol or glycerin

5. Support industry development of industrial products from meals

6. Increase oil supplies by developing closed loop microorganism production systems.

\subsection{Discussion}

Demonstrate and optimize commercial bio-distillate production Bio-distillation research was ranked number one for several reasons. The benefits of producing bio-distillates from using existing infrastructure are significant. Production and distribution costs can be minimized and key political barriers are addressed. Bio-distillates can become a premium additive, where the additional value may offset the higher cost inputs. Biomass oils could displace higher cost 
refinery streams. A stand-alone fuel composed of bio-distillates could even be possible. Emission benefits of either the additive or the stand-alone fuel are not known at this time and need to be identified. So long as existing refinery processes are used, global warming benefits are highly likely based on previous diesel and soy biodiesel life cycle analyses. There are a large number of technical issues that need to be resolved before this technology can be commercialized. What level of incentive would be necessary to breakeven with vegetable oil feedstocks? Why types of logistical issues limit oil displacement, if any? What are the feedstock quality issues? What is the oil displacement potential?

Oil Extraction Technology: Since biomass oil extraction can cost 20 to 44 cents per gallon of oil and up, it provides a large target for cost reductions. Only oil seed costs are higher. Improved oil extraction technology could benefit the existing crushing industry by developing a process that does not use toxic compounds such as $n$-hexane. But the key goal should be cost reduction. There are two key areas for R\&D: reducing the cost of extracting oils from the seeds and reducing pretreatment costs, those processes that remove contaminants from the oils that interfere with product quality (as energy products) or processing systems.

Super critical CO2 oil extraction technology offers some benefits in terms of lower costs, higher oil quality (less pretreatment required), and is suitable for smaller plants. Crown Iron Works have demonstrated this technology in a 50 ton per day crushing pilot plant in MN. The process can accommodate seed moisture content up to $11 \%$ (saves on drying costs), does not require purified $\mathrm{CO} 2$, and the oil quality is similar to refined, bleached and deodorized soy oil (RBD soy oil). Internal cost estimates indicate that this process can be more cost effective than small mechanical crushers that produce crude oil (typically smaller than 500 tons per day). Additional savings are generated because the processes that are typically used to create RBD oil from crude oil are avoided, saving as much as 5 cents per pound or 38.5 cents per gallon of RBD oil. This technology requires demonstration and optimization. As soon as viable technology becomes available it takes 10 to 15 years or longer to displace a significant fraction of existing technology in a mature industry. The EPA is pushing the industry to develop a viable non-hexane substitute so there may be a timely window of opportunity to adopt new technology throughout the entire industry. In addition, new technology would lower the cost structure of the entire U.S. crushing industry and provide it with a competitive advantage in international markets.

Industrial Meal Coproducts: Developing new meal coproducts will stimulate the existing crushing industry, expanding oil supplies and reducing their costs. Demand for soybean meal drives the U.S. crushing industry; demand for oil has no real effect on capacity utilization because it's a minor byproduct representing only $19 \%$ of the soybean by weight. If the demand for meal in industrial coproducts or applications is stimulated, crushing capacity utilization will increase and the amount of oil produced will increase. The price for oils may fall as oil supplies and crusher's revenues expand. There are large numbers of new uses for soy meal in the human food and health products industries. This is an appropriate role for USDA to support. However, since soybean meal prices typically range in the 9 to 10 cents a pound range, there is an opportunity to find new industrial products that could be made from meal. A solicitation may be offered every year until a large market meal coproduct is identified that meets OBP's needs. There are numerous industrial partners with solid credentials to work with in this category (Unites Soybean Board, Battelle National Laboratories, ADM, Cargill, Bunge, AGP, etc.). 
Reduce glycerin refining costs: An inevitable byproduct of biodiesel production is glycerolabout 0.73 pounds per gallon biodiesel. Excess glycerol supplies may never become a problem if the most cost effective future fuel is bio-distillates rather than biodiesel. However, if biodiesel production expands, billions of pounds of glycerol will be produced. For this reason, it is ranked fourth on the priority list. R\&D investments in this area might be delayed until the results of the bio-distillates studies are available. Because most glycerol derivatives are made from $99 \%$ pure glycerol, refining costs are reflected in the cost of glycerol coproducts. Currently refining glycerol costs about $\$ 0.20$ per pound using existing conventional technology. The cost is much higher for small-scale biodiesel plants, since the minimum economic size of a glycerin refining facility is 20 to 30 million gallons per year (biomass oil inputs). Developing a technology for smaller facilities that reduces the cost of refining glycerol will enable biodiesel producers to move into coproduct production.

There are two commercial processes for glycerin refining:

- a conventional process that uses alum or ferric chloride treatment followed by evaporation, distillation, deodorization, and bleaching

- ion exchange followed by evaporation and polishing.

The first is energy intensive and wide spread, the second offers a trade off between lower energy input and higher capital and regeneration costs.

Rather than focus $R \& D$ on refining the glycerin, R\&D could target a key glycerin contaminantthe spent catalysts salts from biodiesel production. An Austrian technology provider, BDT, is offering an autocatalyzed system for high free fatty acid feedstocks (used cooking oils and animal fats), eliminating catalysts. Its drawback is that it requires significant feedstock pretreatment costs (probably to reduce undesired side reactions) that can add 38 cents per gallon or more depending on initial feedstock quality.

High temperature and pressure systems autocatalyze esterification but less energy intensive systems could be developed. Fixed bed, packed reactors, and other immobile catalyst systems might eliminate mobile catalysts without the energy penalties of the high temperature/pressure systems, and produce a higher quality glycerol that requires minimal processing to produce coproducts. These systems may also reduce catalyst input costs for biodiesel production at the same time, since some of the catalyst costs are for catalysts used to neutralize the working catalyst.

Most research in the petroleum world has focused on fixed acid catalysts. Those may be appropriate for acid esterification but fixed base catalysts need to be developed for biodiesel production. Catalyst identification, construction, optimization, and demonstration are all needed to commercial fixed base catalysts. Fortunately, there are a number of approaches that could be explored so that multiple solutions may be developed. These topics could be included in SBIRs and other solicitations to promote improvements in the biodiesel industry.

Develop Glycerol Coproduct Technology: The target markets for glycerol coproducts must be large, as future supplies from a biodiesel driven industry will create billions of pounds of 
glycerol. Typical prices for chemicals produced in these large volumes rarely exceed 50 cents a pound. There are three directions that research could focus on:

- develop new market uses for crude (unrefined) glycerin

- develop new chemistry or products that are chemical derivatives of purified glycerol

- develop new chemistry or produces from crude glycerin in situ (salt free crude glycerin).

Near term DOE assistance can be provided through SBIRs or solicitations with industry partners. As industry identifies products or product chemistries with large-scale market potential, the research needed to move these concepts into commercial status will be better defined, and the role of DOE can be identified.

Fuel uses for glycerin are attractive from a large market perspective but should be avoided unless there is compelling evidence that 1) the glycerin does not cause long term engine damage as seen in previous research studies, and 2) the price structure of the resulting compound can be supported by the fuel market and 3) the industry is willing to partner with DOE to support the $\$ 30$ million dollars required to commercialize a new fuel or fuel additive.

Oil from Closed Loop Micro Organism Production: This country is not currently approaching any constraints with respect to oil supplies and there remain a number of viable options for expanding oil supplies in the near term (to 2015) through USDA research. Research on microorganisms is ranked further down the list of OBP priorities and may well be delayed into later years. Yeasts, molds, fungi and bacteria can be genetically optimized and used to produce oils in closed manufacturing systems using inexpensive biomass substrates, such as crop residues, wood wastes, MSW biomass, or even pyrolysis oils. The non-oil portions of these organisms can be recycled back into production systems, making them truly closed looped. These organisms offer a couple of key benefits compared to the previous EERE micro algae program - major land resources and water resource are not required and the genetically modified organisms are not exposed to the open environment, wildlife, or accidental release. In addition, many of these organisms do not require sunlight for photosynthesis.

Since closed looped production of micro organisms is resembles manufacturing rather than agriculture, it is one feedstock supply research role that might be best suited to DOE. Particularly since DOE has already invested research in some of these areas in the past and has a significant body of knowledge to start from.

This country is not approaching any constraints with respect to current oil supplies and there remain a number of viable options for expanding oil supplies in the near term (to 2015). Thus research on microorganisms is ranked further down the list and may well be delayed into later years. Some inexpensive stage gate analysis and solicitations could be undertaken in the near term to collect information and assess possible pathways for closed loop production of microorganisms. This will lay a foundation for program elements when they become necessary. If these early analyses reveal major benefits (significant oil supplies at exceptionally low costs) then the priority of this program element can be raised and research accelerated. 
Program cost Because the cost of these research elements will be defined in proposals as a result of solicitations and then balanced against other program needs, it is difficult to estimate program costs in advance. Historically the biodiesel program, and its successor the Renewable Diesel Program that supported these research areas, operated on a budget that varied from $\$ 750,000$ to $\$ 1.5$ million per year. Most of the funding was directed towards technical barriers facing the use of biodiesel and E-diesel fuels because the funding levels could not support process development and demonstration. If OBP refocuses their program towards production technology in the areas identified above, $\$ 2$ to $\$ 5$ million per year may be sufficient with careful time phasing of priorities and a focus on only one key element at a time.

Program Timing and Life: The objectives of this research program are relatively concrete and have definite termination points. R\&D to demonstrate, optimize and document costs for biodistillate should be accomplished within three years. Likewise, R\&D to reduce crushing costs could be accomplished in a similar time frame if the super critical CO2 technology is pursued. If not, if another technology appears to offer better advantage, then there may be an additional 1-2 years for engineering and pilot scale demonstrations. Identifying R\&D opportunities for meal coproducts will require persistence by OBP, as concepts must be considered and discarded until one appears to offer all the necessary elements for success. Once identified this effort may require 3 to 5 years of research to commercialize.

It may not be necessary to ever address glycerol refining or coproduct needs if bio-distillates succeed. Otherwise, R\&D to develop, demonstrate, and commercialize better glycerol refining technology or biodiesel technology using fixed catalysts (or no catalysts) may require 3 to 4 years of investments, depending on the progress already made by various industry stakeholders in this area.

Table 35. Biomass Oil R\&D Project Schedule

\begin{tabular}{|l|l|l|l|l|l|l|l|l|l|l|l|}
\hline & 2005 & 2006 & 2007 & 2008 & 2009 & 2010 & 2011 & 2012 & 2013 & 2014 & 2015 \\
\hline $\begin{array}{l}\text { Bio-distillation process } \\
\text { optimization }\end{array}$ & RFP & & & & & & & & & & \\
\hline $\begin{array}{l}\text { Improved Oil extraction } \\
\text { technology }\end{array}$ & RFP & & & & & & & & & & \\
\hline $\begin{array}{l}\text { Develop industrial } \\
\text { products from meal }\end{array}$ & RFP & RFP & & & & & & & & & \\
\hline $\begin{array}{l}\text { Improved glycerin } \\
\text { refining technology }\end{array}$ & & & & RFP & & & & & & & \\
\hline $\begin{array}{l}\text { Coproducts from } \\
\text { glycerin/glycerol }\end{array}$ & & & & & RFP & RFP & & & & & \\
\hline $\begin{array}{l}\text { Develop closed loop oil } \\
\text { producing } \\
\text { microorganisms }\end{array}$ & & & & & & & & & & & \\
\hline
\end{tabular}

Two research elements may pose long-term research investments: glycerol coproducts and new oil supplies from microorganisms. If biodiesel becomes the dominant fuel of the future, there will be a constant need to continue developing new glycerol products, e.g., a glycerol platform research program. Similarly, to facilitate the growth in oil supplies, new organisms can be continually developed that increase oil production, reduce costs, or produce other high value coproducts in addition to oils. Both of these program elements will probably not be funded with 
large amounts of resources until after 2010, when the general direction of petroleum prices and political support become more obvious to OBP managers.

Benefits and Outcomes The result of OBP investment biomass oil R\&D is to create the opportunity to displace up to 10 billion gallons of petroleum diesel per year by 2030 . The resulting fuel costs will appear reasonable to the consumer in blends of 5\% (5 to 10 cent per gallon premium). Fuel blends could be marketed as premium fuels in higher blends in niche markets. At least two different fuels are available as vehicles for this program, providing flexibility and insurance. There are only minor technical barriers associated with the fuels themselves that will not pose significant barriers to market expansion. 


\section{APPENDIX A: OLEOCHEMICAL PRODUCTS}

\section{Fatty Acid Compounds}

Fatty acids (FA) and their derivatives find utility in a large number of applications. However, there is no one single application that consumes the majority of FA produced. The following discussion identifies major fatty acid products and their uses.

\section{Fatty acid amines}

These compounds are derived from the reaction of FA with ammonia to give fatty nitriles. They are subsequently hydrogenated to give primary, secondary, and tertiary amines, which are converted to other materials. These compounds consumed $204 \times 10^{6} \mathrm{lb}$ of FA in 2000.

Other materials in this class include the following:

Quaternary ammonium salts - This consumed $101 \times 10^{6} \mathrm{lb}$ of FA in 2000 . The largest product type is dimethyl dehydrogenated tallow ammonium chloride (DHT quat). It is primarily used as a fabric softener. Products such as Downy, Final Touch, Bounce, and Cling Free use DHT quat. DHT quat is also used as a lubricant and viscosifier in the oil, paint, and lubricant industries. Other uses are found in dyes, textiles, and as additives to a number of materials.

Amines, diamines, ethoxylate amines - This consumed $103 \times 10^{6} \mathrm{lb}$ of FA in 2000. As primary amines, these materials are useful as lubricant additives, and find specific application in industrial gear boxes and oilfield chemicals. Reaction with acrylonitrile (Michael addition) leads to fatty alkyl diamines, used as emulsifiers and lubricants. Reaction of the amines with ethylene oxide leads to ethoxylated amines, useful for the agricultural industry. For example, Roundup is emulsified using an ethoxylated adduct of tallow derived FA.

\section{Other fatty acid derivatives}

This is a broad category of materials, and accounted for the consumption of $1317 \times 10^{6} \mathrm{lb}$ of FA in 2000. The following groups of materials are included:

Esters - Production of esters consumed about $353 \times 10^{6} \mathrm{lb}$ of FA in 2000 , and the products were used in lubricants, plastics, food, personal care products, textiles, fabric softeners, and paper. Esters of both simple and complex alcohols are made. These include glycerol esters of defined structure, which are made by the selective reesterification of glycerol after fat splitting. Approximately $90 \times 10^{6} \mathrm{lb}$ of FA were used to make mono- and diglycerides used as emulsifiers in foods. Another $25 \times 10^{6} \mathrm{lb}$ were used to make personal care products. About $80 \times 10^{6} \mathrm{lb}$ of shorter chain FA (caprylic, C8, and capric, C10) were converted to (for example) pentaerythritol esters for use in synthetic lubricants. About $50 \times 10^{6}$ of oleic acid is converted to glycerol monooleate, which is a fire retardant hydraulic fluid. The material is also used in foods.

Fuel Esters-Approximately $165 \times 106$ lbs of FA were used to produce biodiesel, methyl esters of undifferentiated fatty acids, typically $\mathrm{C} 16$ to $\mathrm{C} 18$. This use appears to be large and growing rapidly worldwide. 
Heavy metal salts - About $239 \times 10^{6} \mathrm{lb}$ of FA were converted to (primarily) metal stearates in 2000. More specifically, these salts included $193 \times 10^{6} \mathrm{lb}$ of dry products (various salts), $80 \times 10^{6}$ $\mathrm{lb}$ of Ca salts as a $50 \%$ aqueous dispersion, and $44 \times 10^{6} \mathrm{lb}$ of Ca salts as a $44 \%$ wax dispersion.

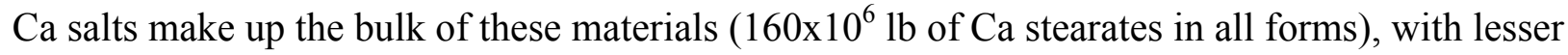
amounts of $\mathrm{Zn}, \mathrm{Mg}, \mathrm{Al}$, and other metal salts making up the remainder. These materials are used mostly in the plastics industry to provide lubrication during molding. 50\% aqueous Ca stearate is used in the paper industry as a lubricant for coated products. Metal stearates use is summarized in Table 36.

Monomer/dimer/trimer acids - Unsaturated fatty acids undergo oligomerization at elevated temperatures to give monomers, dimers, and higher oligomers. This application consumed about $211 \times 10^{6} \mathrm{lb}$ of FA in 2000 . Interestingly, tall oil fatty acids accounted for over $85 \%$ of this use. Dimer acids are used primarily to produce non-nylon polyamide resins. The process also generates about $70 \times 10^{6} \mathrm{lb}$ of monomer fatty acids, such as isostearic acid. Stearic acid is also generated in this process.

Table 36- Industrial Consumption of Metal Stearates

(Chemical Economics Handbook, "Natural Fatty Acids")

\begin{tabular}{|l|c|}
\hline Use & Consumption $\left.\mathbf{( 1 0}^{\mathbf{6}} \mathbf{~} \mathbf{b} \mathbf{- 2 0 0 0}\right)$ \\
\hline \hline Plastics & 170 \\
\hline Paper & 40 \\
\hline \hline Rubber & 15 \\
\hline Food, drugs, cosmetics & 10 \\
\hline \hline Lacquers & 5 \\
\hline \hline Cement & 5 \\
\hline \hline Grease & 4 \\
\hline \hline Petroleum & 2 \\
\hline Textiles & 1 \\
\hline Other & 3 \\
\hline \hline Total & 255 \\
\hline \hline
\end{tabular}

Ester quats - Fatty acids undergo reaction with di- or triethanolamines to give diesters with a tertiary nitrogen. The material is converted to a quat salt with an alkylating agent. This material is finding utility as a replacement for DHT quats. This reformulation has led to considerable growth in this area, consuming $144 \times 10^{6} \mathrm{lb}$ of FA in 2000.

FA-polyamine condensates and quats - Heterocyclic adducts of FA with polyamines (e. g., diethylenetriamine) consumed about $114 \times 10^{6} \mathrm{lb}$ of FA in 2000 . These materials found uses in several applications, including corrosion inhibitors, emulsification, mining, and fabric softeners. 
Anionic specialty surfactants - About $87 \times 10^{6} \mathrm{lb}$ of coconut FA were consumed in this application in $2000.77 \times 10^{6} \mathrm{lb}$ were consumed in the production of acyl isethionates, used in soap products such as Dove, Caress, Lever 200, Oil of Olay, and baby soap.

Fatty acid amides - About $86 \times 10^{6} \mathrm{lb}$ of FA were consumed in the prodution of fatty acid amides in 2000. Most amides were made from long chain FA, such as stearic, oleic, and erucic acids. Their primary application is as slip agents and lubricants in plastics. The largest volume material $\left(52 \times 10^{6} \mathrm{lb} / \mathrm{yr}\right)$ is EBSA [N,N'-ethylenebis(stearamide)], that is used as a lubricant for injection molding. About $70 \%$ of its use is in this application. The remainder is used in textile and paper applications.

Amphoteric Surfactants - About $52 \times 10^{6} \mathrm{lb}$ of FA were used in the production of specialty surfactants. These materials are used in shampoos, dishwashing liquids, liquid hand soaps, and industrial cleaners.

Shorter chain fatty acids - Shorter chain length products are made via ozonolysis of the double bond in oleic acid. Approximately $48 \times 10^{6} \mathrm{lb}$ of oleic acid were converted into azelaic and pelargonic acid. The challenge for this process is balancing the market demand for the two products because they are used in different applications. Azelaic acid esters are a component of plasticizers and synthetic lubricants, while pelargonic acid is the principal component of sodium nonanoyloxybenzene sulfonic acid, used as a bleach activator in detergents.

Alkyl ketene dimers - These materials are used as sizing agents in the paper industry and their manufacture consumes about $33 \times 10^{6} \mathrm{lb}$ of FA.

Other - $\mathrm{CEH}$ also cites the use of about $10 \times 10^{6} \mathrm{lb}$ of FA for other uses.

\section{Fatty acids and their salts}

This category is very large, and consumed $1094 \times 10^{6} \mathrm{lb}$ of FA in 2000 . There are several end uses for these materials.

Cosmetics, soaps, polishes, and household and industrial cleaners - Over $680 \times 10^{6} \mathrm{lb}$ of FA were used in these applications in 2000. CEH notes an interesting market reporting quirk. If a manufacturer is making soaps by continuous saponification of fats and oils, no FA is isolated, and therefore, its production level is not counted as FA production in the oleochemical industry. However, in batch-type noncontinuous processes, the FA is isolated and then neutralized, and is therefore counted in production statistics. Fatty acids are added to soaps such as Dove, Caress, and Lever 2000 in a process called superfatting. Some household detergents, such as Liquid Tide, also contain fatty acids.

Alkyd resins - Alkyd resin coatings require drying oils, and about $85 \times 10^{6} \mathrm{lb}$ of FA were used in this application in 2000. Most FA in these applications came from tall oils, with some additional material being provided from soy oil.

Emulsion polymerization - This process uses FA as emulsifiers, and consumed about $100 \times 10^{6}$ $\mathrm{lb}$ of FA in 2000, particularly in the production of styrene-butadiene rubbers and ABS resins. 
Rubber compounding - Production of rubber uses FA in the vulcanization process, and as a lubricant for the rubber. About $72 \times 10^{6} \mathrm{lb}$ of FA were used in this application.

Animal feed - About $40 \times 10^{6} \mathrm{lb}$ were used as animal feed.

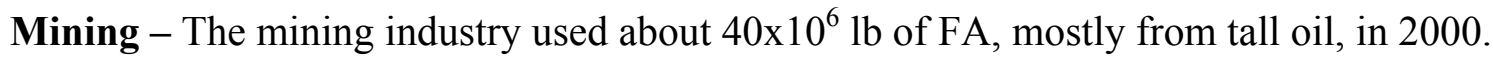

Buffing compounds - Stearic acid is used as a buffing compound, and in $2000,25 \times 10^{6}$ lb were used for this purpose.

Crayons, waxes, and candles - This is a rapid growth segment, particularly with the gradual displacement of wax in candles with fatty acids. About $47 \times 10^{6} \mathrm{lb}$ were consumed in this application in 2000 .

\section{Fatty alcohols}

A large amount of fatty acids are reduced to fatty alcohols for use in the detergent market. Industrially, reduction is carried out continuously on the methyl ester at up to 3000 psi, normally using a copper chromite catalyst. In 1998 , a total of $2265 \times 10^{6} \mathrm{lb}$ of detergent alcohols were produced in North America, Japan, and Western Europe. Again, there is considerable additional capacity $\left(974 \times 10^{6} \mathrm{lb}\right)$ in southeast Asia. Over 94\% of the detergent alcohols in North America were compounds with chain lengths between $\mathrm{C} 12$ and $\mathrm{C} 18$. Table 37 shows how these alcohols were distributed in the three major global market areas.

Table 37. Distribution of Fatty Alcohol Products in North America, Western Europe, and Japan $\left(10^{6} \mathrm{lb}\right)-1998$ (Source: CEH, Detergent Alcohols)

\begin{tabular}{|l|c|c|c|}
\hline Derivative & North America & Western Europe & Japan \\
\hline \hline Alcohol ethoxylates & 805 & 608 & 144 \\
\hline \hline Alcohol sulfates & 60 & 181 & 46 \\
\hline \hline Polymethacrylate esters & 25 & 64 & \\
\hline Fatty nitrogen derivatives & 20 & 35 & \\
\hline Alcohol glyceryl ether sulfonates & 16 & & \\
\hline \hline Alkylpolyglucosides & 16 & & \\
\hline \hline Hindered phenols & 8.5 & & \\
\hline \hline Thiodpropionate esters & 6 & 11 & \\
\hline \hline Other & 15.5 & 159 & 40 \\
\hline \hline Free alcohols, $\mathrm{C}_{12}-\mathrm{C}_{18}$ & 41 & & 24 \\
\hline \hline $\mathrm{C}_{20+}$ alcohols & 20 & & \\
\hline \hline Consumer inventory & 3 & & 254 \\
\hline \hline Total & 1036 & 1058 & \\
\hline
\end{tabular}


Production of detergent alcohols can be "natural," starting from the alcohol exchange reaction on triglycerides, or synthetic, relying on the use of hydrocarbons to build up mixtures of long chain alcohols. In North America, a significant proportion of detergent alcohols (78\%) are made synthetically. The trend reverses somewhat in Europe, with 59\% of detergent alcohols being made from natural sources. Production in Europe also exceeds that in North America, with $1170 \times 10^{6}$ and $1466 \times 10^{6} \mathrm{lb}$ being produced, respectively. In recent years, all new capacity is based on natural oils, reflecting the interest in SE Asia for greater commercialization of palm, palm kernel, and coconut oils. A limitation to producing synthetic oils is that unsaturated fatty alcohols cannot be made by this method. High pressure hydrogenation of natural fatty acids over the appropriate catalyst will selectively reduce the ester group and leave the olefin untouched. ${ }^{88}$

The cost comparison between natural and synthetic detergent alcohols is interesting (Table 38). In all cases, natural sources of detergent alcohols are less expensive than their synthetic counterparts. In addition, many of the synthetic materials are mixtures of a relatively large number of different chain lengths, reflecting the nonselective nature of their manufacture, normally through catalytic oligomerization of lower olefins.

The greater proportion of synthetic oils in the North American detergent market most likely reflects the entrenched position of the petrochemical industry and the desire to use existing capital and technology, rather than an economic benefit. The situation in Europe is reversed, with the prices for natural oils being higher than those of synthetics.

A potentially large opportunity could exist for these materials, as the general surfactant market is huge. In 2000, almost $11 \times 10^{9} \mathrm{lb}$ of detergents were consumed in the United States. alone, and all of it requires the addition of some form of surfactant. Worldwide, the total surfactant market is almost $21 \times 10^{9} \mathrm{lb}$ (Hill, K.; Pure Appl. Chem. 2000, 72, 1255). As stated in the Chemical Economics Handbook (CEH, Surfactants, Household Detergents and Their Raw Materials):

"The choice of surfactant used in a detergent involves a detailed cost/performance evaluation of the entire formulation. A complex matrix of formulations might ideally achieve acceptable performance and provide the manufacturer with considerable latitude in minimizing costs, depending upon the prevailing raw material prices at the time."

The point becomes that, with proper study and partnership with industrial experts, FA based surfactants stand to capture a larger portion of a huge market, greatly increasing the impact of renewables on that segment of the industry.

\section{Fatty Alkanolamides}

A smaller outlet for the consumption of fatty acids is the fatty alkanolamide market. Fatty alkanolamides are produced from the reaction of FA with dialkanolic amines. The market is generally decreasing, as the material has been superceded by other FA derivatives. In 2000, the United States consumed $24 \times 10^{3}$ tonnes of fatty alkanolamides.

\footnotetext{
${ }^{88}$ Kreutzer, U. R.; J. Am. Oil Chem. Soc. 1984, 61, 343.
} 
Table 38. Comparative Prices of Natural and Synthetic Detergent Alcohols - 1999

(Source: CEH, Detergent Alcohols)

\begin{tabular}{|c|c|c|c|}
\hline $\begin{array}{l}\text { Chain } \\
\text { length }\end{array}$ & $\begin{array}{l}\text { Trade name } \\
\text { source }\end{array}$ & $\begin{array}{l}\text { Synthetic oil price } \\
\text { (\$/lb) }\end{array}$ & $\begin{array}{l}\text { Natural oil price } \\
\text { (\$/lb) }\end{array}$ \\
\hline $\mathrm{C}_{12}$ & Alfol 12 & 1.15 & \\
\hline $\mathrm{C}_{12}$ & Alfol 14 & 1.15 & \\
\hline $\mathrm{C}_{12}-\mathrm{C}_{14}$ & Epal 1214 & 0.91 & \\
\hline $\mathrm{C}_{12}-\mathrm{C}_{14}$ & Alfol 1214 & 0.95 & \\
\hline $\mathrm{C}_{12}-\mathrm{C}_{14}$ & Alfol 1412 & 1.19 & \\
\hline $\mathrm{C}_{12}-\mathrm{C}_{14}$ & Alfol 1216 & 0.95 & \\
\hline $\mathrm{C}_{12}-\mathrm{C}_{14}$ & CO 1214 & & 0.70 \\
\hline $\mathrm{C}_{12}-\mathrm{C}_{15}$ & Neodol 25 & 0.82 & \\
\hline $\mathrm{C}_{12}-\mathrm{C}_{13}$ & Neodol 23 & 0.82 & \\
\hline $\mathrm{C}_{14}-\mathrm{C}_{15}$ & Neodol 45 & 0.82 & \\
\hline $\mathrm{C}_{14}-\mathrm{C}_{16}$ & Epal 1416 & 0.82 & \\
\hline $\mathrm{C}_{14}-\mathrm{C}_{18}$ & Epal 1418 & 0.91 & \\
\hline $\mathrm{C}_{16}$ & CO 1695 & & 0.75 \\
\hline $\mathrm{C}_{16}-\mathrm{C}_{18}$ & Alfol 1618 & 1.03 & \\
\hline $\mathrm{C}_{16}-\mathrm{C}_{18}$ & TA 1618 & 0.70 & \\
\hline $\mathrm{C}_{16}-\mathrm{C}_{20}$ & Alfol 1620 & 0.93 & \\
\hline $\mathrm{C}_{16}-\mathrm{C}_{18}$ & Epal 1618 & 0.84 & \\
\hline $\mathrm{C}_{18}$ & & & 0.75 \\
\hline $\mathrm{C}_{20+}$ & Epal 20+ & 0.66 & \\
\hline $\mathrm{C}_{20+}$ & Alfol 20+ & 0.70 & \\
\hline
\end{tabular}

\section{Glycerol Products}

Glycerol is currently a well recognized item of commerce with an annual world production of $600-750 \times 10^{3}$ tonnes. In 1945, the work of Leffingwell described over 1500 different uses for glycerol. ${ }^{89}$ Other sources have rolled up these uses into fewer categories (Table 39).

Glycerol and various simple derivatives of glycerol (such as glycerol triacetate, glycerol stearate, and glycerol oleate) are currently produced by the chemical industry at companies such as Uniqema, Proctor and Gamble, and Stepan. ${ }^{90}$ These materials find application in many of the categories shown in Table 40.

${ }_{90}^{89}$ Leffingwell, G.; Lesser, M. Merck Index, $11^{\text {th }}$ edition, p. 705 (1945).

${ }^{90}$ Uniqema - http://www.uniqema.com/tech/index.htm 
Table 39 Uses of Glycerol, 1995 (source: Claude, S. Fett/Lipid 1999, 101, 101)

\begin{tabular}{|l|c|}
\hline \multicolumn{1}{|c|}{ Application } & $\begin{array}{c}\text { Consumption } \\
\text { (tons) }\end{array}$ \\
\hline Cosmet./Soap/Pharmacy & 202,200 \\
\hline Alkyd resins & 43,800 \\
\hline Food and drinks & 57,700 \\
\hline Polyglycerols & 89,000 \\
\hline Tobacco & 25,500 \\
\hline Cellulose films & 35,000 \\
\hline Esters & 93,400 \\
\hline Paper & 7,300 \\
\hline \hline Nitrates & 2,900 \\
\hline Resale & 103,700 \\
\hline \hline Others & 69,500 \\
\hline Total & 730,000 \\
\hline
\end{tabular}

The feature that unifies these reports is that, for the most part, glycerol consumption statistics are the result of a large number of small volume applications. That is, there are few, if any, uses of glycerol in large quantities for a single product. This is not unusual for a chemical whose market price hovers between $\$ 0.70-0.90 / \mathrm{lb}$. This cost allows very little opportunity for a glycerol based process to afford an additional process step for glycerol structural modification. Thus, many of these current outlets will quickly become saturated by even a relatively small increase in the amount of available glycerol from biodiesel. The diversity of the glycerol market is better understood with a more detailed examination of the current market segments addressed.

Personal care products In $2001,97 \times 10^{6} \mathrm{lb}$ of glycerol were consumed to produce $58 \times 10^{6} \mathrm{lb}$ of skin care products $(60 \%$ of the total; suntan lotions, cleansing wipes and cloths, creams, other cosmetics and toiletries), $29 \times 10^{6} \mathrm{lb}$ for hair care $(30 \%$ of the total; moisturizers and conditioners), and $10 \times 10^{6} \mathrm{lb}$ for soaps (10\% of the total; Neutrogena, designer soaps). This market is increasing at $3.1 \% / \mathrm{yr}$.

Oral care products $\mathrm{In} 2001,69 \times 10^{6} \mathrm{lb}$ of glycerol were consumed, $52 \times 10^{6} \mathrm{lb}$ for toothpastes $(75 \%)$ and $17 \times 10^{6}$ for mouthwashes $(25 \%)$, with the market increasing at $2 \% / y r$. The primary competition is the less expensive sorbitol, however, sorbitol does not possess optimum taste and solubility properties. Low cost glycerol could capture more of the sorbitol market.

Stepan - http://www.stepan.com/aboutstepan/about.asp

Proctor and Gamble -

http://www.pg.com/frameset_fs.jhtml?frameURL=http\%3A//www.pgchemicals.com 
Drugs Glycerol is used to increase smoothness and lubrication, and in the production of gel caps. It is also used in suppositories, cough syrups, expectorants, etc.

Table 40. Table - Production, Consumption, and Uses of Glycerol, 2001 (in thousands of tonnes; Source: Chemical Economics Handbook)

\begin{tabular}{|l|c|c|c|c|}
\hline \multicolumn{1}{|l|}{} & U. S. & Europe & Japan & Total \\
\hline Annual capacity & 169 & 315 & 59 & 543 \\
\hline Production & 159 & 247 & 53 & 459 \\
\hline Consumption & & \multicolumn{2}{|c|}{} & \multicolumn{2}{|c|}{} \\
\hline Personal/oral care products & 75 & 46 & 15.5 & 136.5 \\
\hline Drugs/Pharmaceuticals & 14 & 24 & 23 & 61 \\
\hline Foods/beverages & 42 & 27 & & 69 \\
\hline Polyether polyols & 17 & 33 & 6 & 56 \\
\hline Tobacco & 22 & 15 & 5 & 42 \\
\hline Alkyd resins & 6 & 17 & 7.5 & 30.5 \\
\hline \hline Other & 13 & 79 & 29 & 121 \\
\hline
\end{tabular}

Foods and beverages In $2001,92 \times 10^{6} \mathrm{lb}$ of glycerol were consumed, with $5 \times 10^{6} \mathrm{lb}$ used for meat casings and the remainder finding application in many different areas, such as emulsifiers, humectants, heat transfer media, flavors and colors, sweeteners, edible plasticizers (i. e., raisins saturated with glycerol remain soft when mixed with cereals, Lowen R. Morrison, Procter \& Gamble,Kirk-Othmer Encyclopedia of Chemical Technology (1994)). Certain glycerol esters, such as glycerol mono and distearate, are used for reduced fat foods. Polyglycerols find use as emulsifiers. Primary competition in this market segment is again sorbitol. However, sorbitol comes as a water solution, which is a problem for food manufacturers who want to minimize added water in their products. A source of cheap glycerol could offer opportunities to recapture some of this market. These market applications are increasing at 3\%-3.5\%/yr

Tobacco In 2001, the tobacco industry consumed 49 $10^{6} \mathrm{lb}$ of glycerol. $7.4 \times 10^{6} \mathrm{lb}$ were used to produce triacetin (glycerol triacetate) as a plasticizer (15\% of the total consumption). Glycerol is also an important humectant. Competition again comes from other polyols, such as sorbitol and propylene glycol.

Other Glycerol has also found use in the production of other materials. The explosives industry used $2 \times 10^{6} \mathrm{lb}$ of glycerol in 2001. Other uses include production of polyether polyols (foams for furniture, car seating, carpet underlay, packaging) and alkyd resins (coatings), both of which are large volume markets that could offer an opportunity to expand glycerol's utility. Glycerol also is used as a plasticizer, humectant, lubricant, and in textiles, photography, gas drying, and production of electrolytic capacitors. These other uses account for consumption of $25-30 \times 10^{6} \mathrm{lb}$ in 2001 . 


\section{REPORT DOCUMENTATION PAGE}

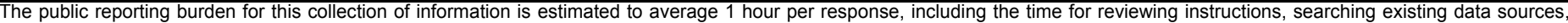

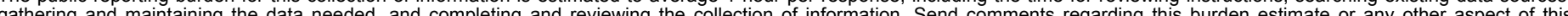

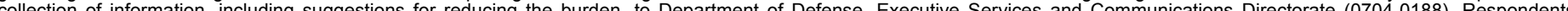

should be aware that notwithstanding any other provision of law, no person shall be subject to any penally fo

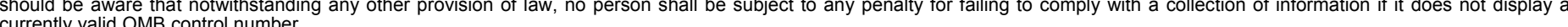

PLEASE DO NOT RETURN YOUR FORM TO THE ABOVE ORGANIZATION.

\begin{tabular}{l|l|l|l} 
1. REPORT DATE $(D D-M M-Y Y Y Y)$ & 2. REPORT TYPE & 3. DATES COVERED (FrOm - TO)
\end{tabular}

June 2004

Technical Report

4. TITLE AND SUBTITLE

Biomass Oil Analysis: Research Needs and Recommendations

5a. CONTRACT NUMBER

DE-AC36-99-GO10337

5b. GRANT NUMBER

5c. PROGRAM ELEMENT NUMBER

6. AUTHOR(S)

K. Shaine Tyson, Joseph Bozell, Robert Wallace, Eugene Petersen, Luc Moens

5d. PROJECT NUMBER

NREL/TP-510-34796

5e. TASK NUMBER

BBA35210

5f. WORK UNIT NUMBER
7. PERFORMING ORGANIZATION NAME(S) AND ADDRESS(ES)

National Renewable Energy Laboratory

1617 Cole Blvd.

Golden, CO 80401-3393
8. PERFORMING ORGANIZATION REPORT NUMBER

NREL/TP-510-34796

9. SPONSORING/MONITORING AGENCY NAME(S) AND ADDRESS(ES)

10. SPONSOR/MONITOR'S ACRONYM(S) NREL

11. SPONSORING/MONITORING AGENCY REPORT NUMBER

12. DISTRIBUTION AVAILABILITY STATEMENT

National Technical Information Service

U.S. Department of Commerce

5285 Port Royal Road

Springfield, VA 22161

13. SUPPLEMENTARY NOTES

14. ABSTRACT (Maximum 200 Words)

Report analyzing the use of biomass oils to help meet Office of the Biomass Program goals of establishing a commercial biorefinery by 2010 and commercilizing at least four biobased products.

15. SUBJECT TERMS

biomass oil; biodiesel; biorefinery

\begin{tabular}{|c|c|c|}
\hline $\begin{array}{l}\text { a. REPORT } \\
\text { Unclassified }\end{array}$ & $\begin{array}{l}\text { b. ABSTRACT } \\
\text { Unclassified }\end{array}$ & $\begin{array}{l}\text { c. THIS PAGE } \\
\text { Unclassified }\end{array}$ \\
\hline
\end{tabular}

\begin{tabular}{|c|c|}
\hline $\begin{array}{l}\text { 7. LIMITATION } \\
\text { OF ABSTRACT }\end{array}$ & $\begin{array}{l}\text { 18. NUMBER } \\
\text { OF PAGES }\end{array}$ \\
\hline UL & \\
\hline
\end{tabular}

19a. NAME OF RESPONSIBLE PERSON

19b. TELEPONE NUMBER (Include area code) 